\title{
BRASIL E OS ACORDOS INTERNACIONAIS DE CACAU, CAFÉ E AÇÚCAR: 1962 - 1982
}

SOCORRO DE MARIA ARRAES MENEZES

Orientador: FLÁVIO ABRANCHES PINHEIRO

Dissertação apresentada à Escola Superior de Agricultura "Luiz de Queiroz", da Universidade de São

Paulo para obtenção do título de Mestre em Agronomia - Área de Concentração: Economia Agrária.

$P|R A C| C A B A$

Estado de São Paulo - Brasil Maio de 1985 
Aos meus pais,

Maria da Cruz e Valdemir 


\section{AGRADECIMENTOS}

A Comissão Executiva do Plano da Lavoura Cacaueira-CEPLAC, na pessoa dos senhores José Haroldo Castro Vieira e Emo Ruy de Miranda;

Ao Prof. Flávio Abranches Pinheiro pela eficiente orienta ção e amizade;

Ao Prof. Adriano Romariz Duarte pelas valiosas sugestões e criticas apresentadas a este estudo;

Aos Professores Evaristo Marzabal Neves, Cicely Moitinho Ama ral e José Ferreira de Noronha pelas críticas e suges töes;

Aos Colegas de curso lsabel C. Takitane, Roberto A. Fassare la, João Aurēlio Viana, Eldis Barne Molina e Rafael Fuen tes Llanillo pelo estímulo e amizade;

Ao Sr. Jorge Raymundo Castro Vieira pelo apoio e compre ensão;

Aos Colegas Helio Estrela Barroco, James R. Lafleur, Marilü Pacheco de G. Teixeira, Paulo de Tarso Lima, Ricardo R. Tafani, pelo incentivo e apoio;

Aos Colegas Márcio R. Torres, Reinaldo S. de Mello pelo aten dimento sempre atencioso;

Ao Centro de Computação e Informática - UNESP - Botucatu, na pessoa dos senhores Angelo Catoneo e Jaime Laperuta Filho;

As Colegas Cleide Bazanelli, Tanni Werneck pelo apoio e so I idariedade; e

A Margareth A. Braga Leal de Souza, pelo cuidadoso traba I ho de datilografia. 


\section{TNDICE}

Pàgina

LISTA DE TABELAS ...................... v

RESUMO $\ldots \ldots \ldots \ldots \ldots \ldots \ldots \ldots \ldots \ldots \ldots \ldots \ldots \ldots \ldots \ldots \ldots$

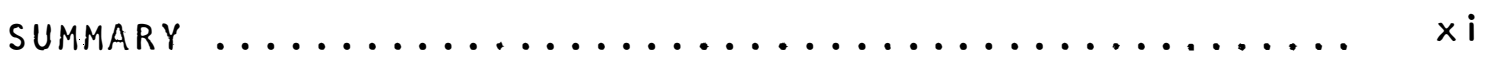

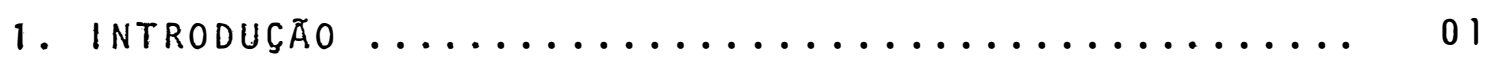

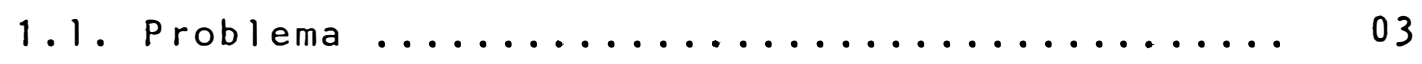

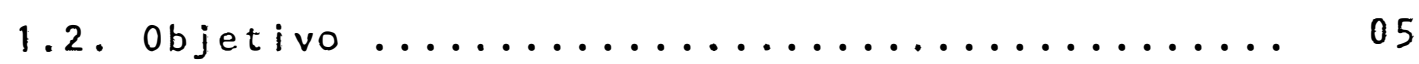

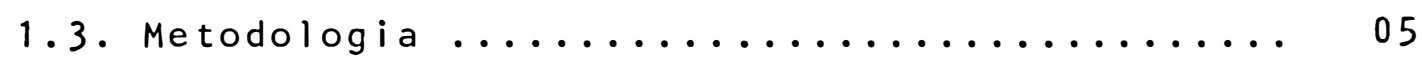

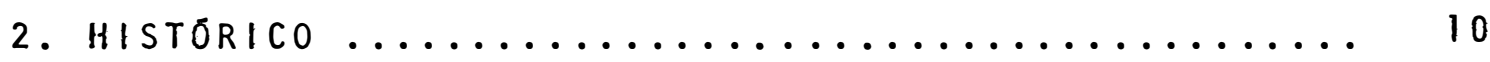

2.1. Acordos internacionais de cacau ........... 10

2.2. Acordos internacionais de café ............ 26

2.3. Acordos internacionais de açücar ......... 44

3. EVOLUÇÃO dO MERCADO INTERNACIONAL DE

CACAU, CAFE E ACUCAR .................... 58

3.1. Mercado internacional de cacau ............ 59

3.1.1. Grau de concentração das exportações brasileira de cacau em amêndoas ...... 77

3.2. Mercado internacional de café ............. 79

3.2.1. Grau de concentração das exportações brasileira de café cru em grãos ...... 90

3.3. Mercado internacional de açūcar .......... 92

3.3.1. Grau de concentração das exportações brasileira de açūcar demerara ........ 106

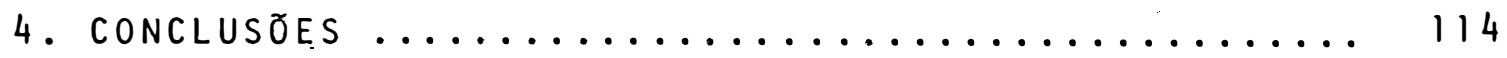

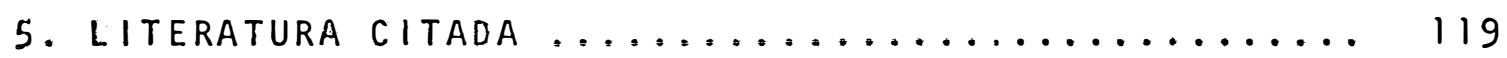


Tabela n?

$0:$ Valor da exportação total brasileira, ex. portação brasileira de café cruem grãos e solūvel e participação percentual 1963 -

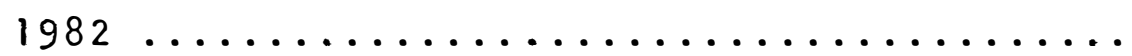

02 Preços médios das exportações brasileira

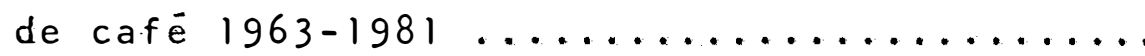

03 Participação percentual dos principais países exportadores nas exportações mun dia is de café crú em grãos 1962-1981 ......4 40

04 Produção mundial de cacau em amêndoas e produção dos principais países produtores

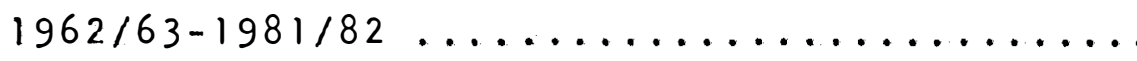

05 Taxa geométrica anual de crescimento de cacau em amêndoas e derivados 1962-1982 ......

06 Participação percentual dos principais países exportadores nas exportações mun dia is de cacau em amêndoas 1962-1981 ........

07 Volume da exportação brasileira de cacau em amêndoas e derivados e participação

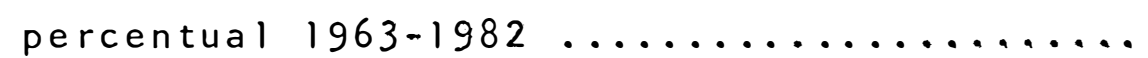

08 Valor e volume da exportação brasileira de cacau em amêndoas por países importa-

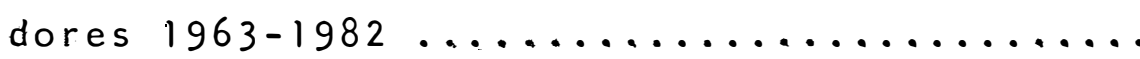

09 Valor da exportação total brasileira, ex portação brasileira de cacau em amēndoas e derivados e particípação percentual

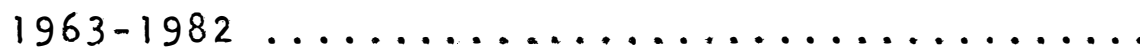


Volume da importação mundial de cacau em amêndoas e importação dos principais paí ses importadores 1972-1981/82 ........... 72

11 Volume da oferta e demanda mundial de ca cau em amêndoas 1960/61-1981/82 ......... 75

12 Indice de Gini: cacau em amêndoas 1963-

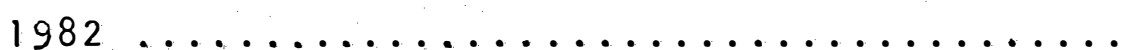

13 Produção mundial de café verde e produ ção dos principais países produtores,

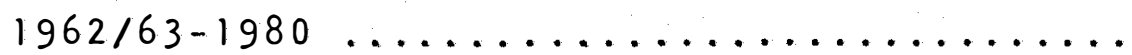

14 Participação percentual dos principais países produtores na produção mundial de

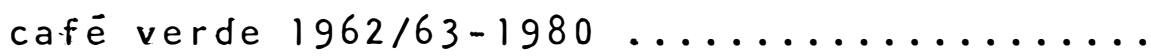

15 Taxa geométrica anual de crescimento de café crú em grãos e solūvel 1963-1981 ........

16 Participação percentual dos principais países exportadores nas exportações mun diais de cafée cru em grãos $1962-1981 \ldots \ldots \ldots \ldots$

17 Volume da oferta e demanda mundial de ca

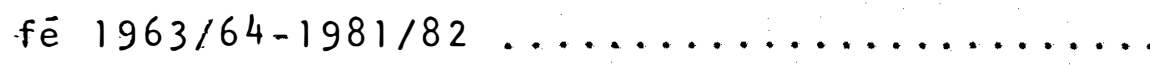

18 Consumo brasileiro de café crü em grãos

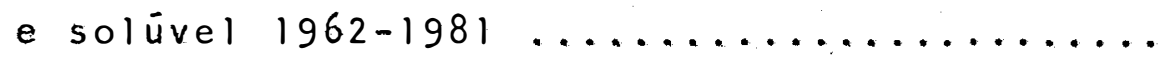

19 Indice de Gi.ni: café crú em grãos 1963-

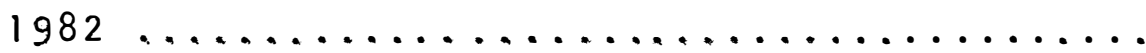

20 Produção mundial de açūcar e produção dos principais países produtores 1962/63

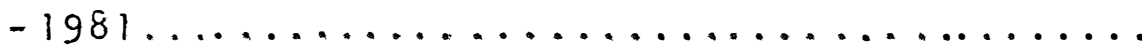

21 Taxa geométrica anual de crescimento de

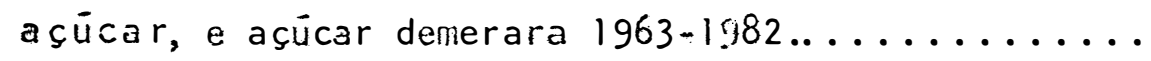


22 Participação percentual dos pri ncipais países exportadores nas exportações mun-

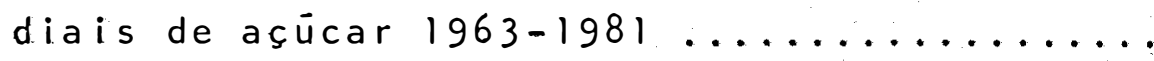

23 Volume da exportação brasileira de açú car, açūcar demerara e participação per

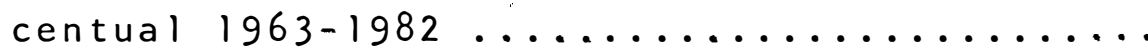

24 Valor da exportação total brasileira, ex portação brasileira de açūcar, açūcar de merara e participação percentual 19631982

25 Participação percentual dos principais países importadores nas importações mun

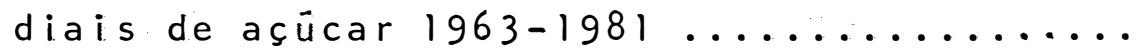

26 Preços médios das exportações de açūcar e de açūcar demerara 1963-1982 ............. 102

27 Volume da oferta e demanda mundial de açūcar 1972/73-1981/82 ......................104

28 Produção e consumo brasileiro de açūcar e participação percentual 1963-1979 ........

29 - Indice de Gini: açūcar demerara 1963-

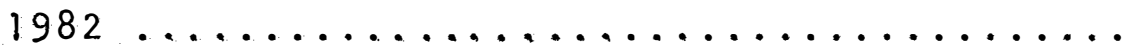

30 Valor e volume da exportação brasileira de açúcar demerara por países importado

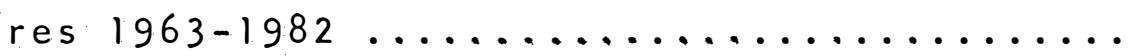

Apêndice $n$

Valor e volume da exportação brasileira de café cru em grãos por países importa-

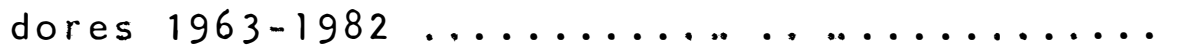




\section{BRASIL E OS ACORDOS INTERNACIONAIS DE}

CACAU, CAFE E AÇOCAR: 1962-1982

\section{Autora: Socorro de Maria Arraes Menezes}

\section{Orientador: Flāvio Abranches Pinheiro}

\section{RESUMO}

0 mercado internacional de "commodities" carac teriza-se por frequentes oscilações de preços. A instabilida de nos preços das "commodities" levou países produtores e con sumidores a negociarem Acordos Internacionais, com o objetivo de estabilizar os preços.

Entre as principais "commodities" comerciali zadas no mercado internacional, destacam-se cacau, café e açú car. Sendo o Brasil grande produtor e com participação sign $\underline{i}$ ficativa no comércio mundial destes produtos, o estudo tem co mo objetivo analisar as negociações dos Acordos Internacionais de Cacau, Café e Açūcar assim, como a evolução do mercado in ternacional destes produtos, enfatizando as dificuldades de negociações e os efeitos dos respectivos acordos.

Inicialmente apresenta-se uma retrospectiva histörica das negociações para implementação dos Acordos In ternacionais de Cacau, Café e Açúcar. Procura-se destacar os principais objetivos e mecanismos propostos para a formaliza ção destes Acordos, assim, como os pontos de maior divergēn cia entre países produtores e consumidores de cada produto.

Em seguida analisa-se evolução do mercado in ternacional de cacau, café e açücar no período 1962-1982. 
Através do comportamento dos principais indicadores, como pro dução, exportação, consumo e preços de exportação destas "commodities", destaca-se o caso do Brasil. Procura-se tam bém relacionar o comportamento do comércio internacional des tes produtos, com a atuação dos respectivos acordos e com as politicas adotadas pelo Governo brasileiro de incremento do comércio exterior a partir de meados da dēcada de 60.

Na análise do comportamento do mercado interna cional de cacau, café e açūcar e da atuação dos acordos inter nacionais destes produtos, salienta-se que as dificuldades de entendimento entre países exportadores e importadores durante as negociações dos Acordos, são atribuídas particularmente, as distintas caracteristicas dos países participantes destes Acor dos. De um lado, países industrializados, do outro países em desenvolvimento. A fragilidade dos países exportadores diante dos importadores, é atribuída entre outros fatores, a faltade sistemas adequados de estocagem e de habilidade para conter a expansão da produção do produto, uma vez que em sua maioria são dependentes das exportações de produtos primários.

As anälises deste estudo, mostram que de modo geral, os Acordos, com seus mecanismos de estabilização de preços, não têm surtido o efeito esperado. Verifica-se que os desequilibrios entre oferta e demanda têm anulado os esforços dos paises exportadores e importadores, na busca de estabilização de preços no mercado internacional. Tal situação pode ser atribuida a falhas nas expectativas e previsões de oferta e demanda por parte dos países negociadores dos acordos destas "commodities".

Ressalta-se que em geral, o Acordo Internacio nal do Café tem sido efetivo. Com seus mecanismos de estabili zação, notadamente cota de exportação, vem sendo possível man 
ter os preços do produto relativamente estáveis, o que pode ser atribuído a polittica de comercialização e estocagem do produto, assim, como maior integração entre os grandes países produtores.

0 Brasil possui determinadas condições que o coloca em posição favorável nas negociações dos Acordos Inter nacionais destas "commodities". Ao possuir um sistema adequado de estocagem e elevado consumo interno, notadamente, de ca fé e açūcar, o país conta com alternativas favoráveis, para redução das flutuações de preços no mercado externo.

Embora a estratēgia instituída pelo governo brasileiro de expansão das exportações venha alcançando resul tados favoráveis, o Brasil deveria rever sua política de co mërcio exterior, não só com o objetivo de ampliar as vendas para os compradores tradicionais, mas, principalmente, para conquista de novos mercados. 0 incremento das exportações ë o meio de aumento da renda e, entrada de divisas. Entretanto, a diversificação é uma política que diminui a vulnerabilidade e limitações impostas pelo mercado internacional.

Verifica-se que embora os efeitos dos Acordos Internacionais destas "commodities", sejam de curto prazo, a existência dos mesmos é de suma importância pois, além de constituir o respaldo político dos países em desenvolvimento, funcionam como elemento psicolögico de estabilização de pre ços no mercado internacional. 


\author{
BRAZIL AND THE COCOA, COFFEE \\ AND SUGAR INTERIATIONAL AGREEMENTS - 1962-1982
}

Author: Socorro de Maria Arraes Menezes

Adivisor: Flävio Abranches Pinheiro

SUMMARY

The commodities international market is characterized by frequent price fluctuation. The instability of commodities price has led producer and consumer countries to make International Agreements aiming to the stabilization of prices.

Among the main commodities traded at the international market cocoa, coffee, and sugar outstand. Since Brazil is a great producer participating actively in the world trade of these products this study has as its main objective to analyse the Cocoa, Coffee and Sugar International Agreements negotiations as well as the evolution of these products international market, emphasizing the negotiations difficulties and the effects of the above mentioned agreements.

The analysis of this study show that in general the agreements with their price stabilization mechanisms have not had the expected effects. It can be seen that the unbalance between supply and demand have nullified the export and import countries efforts in the search of price stabilization at the international market. This situation can be attributed to the faulty expectations and forecasts concerning supply and demand from the part of those commodities agreement negotiators countries. 
It is noteworthy that in general the Coffee International Agreement has been efficient. With its stabilization mechanisms, notedly the exportation quota, it has made possible to maintain the product price relativily stable, what can be attributed to the commercialization and stocks policy for the product, as well as to a greater interaction among the great producer countries.

Brazil presents particular characteristics which place it in a favorable position at the International Agreement negotiations for these commodities. Having a well suited storing system and a high domestic comsumption, specially for coffee and sugar, the country can count on favorable alternatives to reduce price fluctuations at the foreign market.

Although the Brazilian government strategies for the expansion of exports have been achieving favorable results, Brazil should review its foreign exchange trade policy, not only. with the objective to increase sales to traditional buyers, but also and specially, to win new markets. The increase of exports is the means to increase revenue and foreigncurrencies income. However, diversification is a policy which disminishes the vulnerability and limitations imposed by the international market.

It is observed that although the effects of these commodities International Agreements are of short term, their existence is highly important because they serve as political support to the developing countries and besides that they act as psychological factors to the stabilization of prices at the international market. 
1. INTRODUÇÃO

os países industrializados caracterizam-se por serem exportadores de produtos manufaturados, não dependendo basicamente das exportações de matērias primas agrícolas para o equilibrio de suas balanças comerciais.

os países em desenvolvimento são produtores/ex portadores de uma significativa parcela de produtos agrico las. Estes países, em sua maioria, são dependentes das expor tações dos produtos primārios, sendo que, em muitos deles, as exportações agricolas constituem a principal fonte de divi sas.

Dentre as diversas "commodities" comercializa das no mercado internacional, destacam-se o cacau, café e açü car. Tanto do lado da oferta como da demanda, o mercado des tes produtos apresenta-se concentrado.

0 mercado de "commodities" caracteriza-se por constituir-se de produtos primários sujeitos a grandes flutua ções de preços. De modo geral, as "commodities" são comercial zadas em Bolsas de Mercadorias, assegurando basicamente aos produtores, menores riscos dado as constantes flutuações de 
preços. As operações de compras e vendas são efetuadas atra vés de contratos em dois tipos de mercado-mercado físico onde a compra ou venda do produto verifica-se para entrega imedia ta e mercado a termo ou futuro onde a compra ou venda do pro duto se dá através de um compromisso a ser realizado no futu ro. O maior volume comercializado das "commodities" verifica- se nos meses referentes ao encerramento das safras de acor do com cada produto. Yo (1980).

Estes produtos primārios apresentam inelastici dade de demanda e oferta no curto e médio prazo. Pelo lado da demanda deve-se especialmente, ao fato destes produtos aten derem às necessidades bảsicas dos países consumidores e a falta de produtos substitutos prōximos. Com relação a oferta deve-se a fatores técnicos como a resposta da produção no lon go prazo, dado que em geral a cultura destes produtos primári os é de ciclo longo.

Neste estudo, as anälises dos Acordos e do mer cado internacional de cacau, café e açūcar devem-se ao fato do Brasil ser grande produtor e com participação significativa nas exportações mundiais destas "commodities". O período de análise 1962-1982 deve-se às medidas de incentivos atravès da politica cambial, comercial e fiscal adotadas pelo Governobra sileiro a partir da crise econômica e politica de 1964, com o objetivo de aumentar e diversificar as exportações brasileira. Sendo que as políticas de incremento e diversificação das ex portações brasileira implementadas na década de 60 , obtiveram resultados significativos a partir dos anos 70 .

As frequentes flutuações de preços das "commodities" no mercado internacional desde a década de 20 , têm le vado países produtores e consumidores a esforços conjuntos pa ra estabilização de preços. A característica de concentração 
tanto do lado da oferta como da demanda destas "commodities" seria um fator favorável, para um melhor entendimento entre países produtores e consumidores na busca do principal objetivo, de estabilização do comércio mundial.

Os intensivos e constantes debates nas negocia ções dos Acordos Internacionais de "commodities" entre paises produtores e consumidores, mostram o interesse dos participan tes, em torno de adoção de uma política de comércio interna cional visando à estabilização dos preços.

\section{1. Problema}

A receita cambial proveniente das exportações de produtos primários constitui-se uma das principais fontes de divisas para a maioria dos paises em desenvolvimento. Con tudo, as flutuaçoes de preços das "commodities", decorrentes de variação de oferta e demanda, geram sérios problemas para a economia dos países em desenvolvimento.

Os desequilibrios entre a oferta e demanda le vam a grandes flutuações de preços. Tais flutuações levaram diversos países, desde a década de 20 , a tentarem a formaliza ção de Acordos Internacionais de "commodities". Argumentava-se que as flutuações de preços não podiam ser corrigidas pelas forças normais de mercado, isto é, o mercado precisaria de a gum tipo de intervenção com objetivo de reduzir as flutuações de preços.

O principal objetivodos Acordos Internacionais de "commodities" è a estabilização de preço, operando através de mecanismos tais como, cotas de exportação, faixa de preços máximo e mínimo e estoques reguladores. 
Deve-se destacar as dificuldades para implemen tação de Acordos Internacionais deste tipo, visto que países participantes, produtores e consumidores, possuem caracteristicas e interesses distintos. De modo geral, os países produ tores estão em fase de desenvolvimento, enquanto os consumidores são países desenvolvidos.

A dificuldade dos países consumidores e expor tadores para chegarem ao consenso, dizem respeito à não aceitação por parte de alguns, da forma de atuação dos mecanismos a serem utilizados para alcançar o objetivo de estabilização de preços. A divergência muitas vezes, refere-se ao nível de preço a ser fixado, de forma que seja compensador aos diversos países participantes do mercado; à determinação das cotas de exportação, (de que maneira distribuir as cotas entre os países produtores de modo a não haver discriminação) e também a capacidade física, financeira e operacional do mecanismo do estoque regulador. A grande polêmica deste ūltimo mecanismo, refere-se ao montante de financiamento e sua maneira de intervenção.

Por outro lado, muitos países consumidores a gumentam que os Acordos são uma maneira de transferência de recursos dos países ricos para os países pobres, especialmente, sendo a demanda da "commodity" inelástica em relação ao preço.

Um outro problema, é que os interesses de grü pos poderosos (países consumidores) se sobrepõem, dada a vul nerabilidade dos países em desenvolvimento, por não possuírem sistemas adequados de estocagem e habilidade para reter a ex pansão da produção, uma vez que são altamente dependentes das exportações de produtos primārios. As medidas conjuntas, atra vès de mecanismos disciplinadores de mercado, deveriam se 
sobrepor aos interesses dos países negociadores, para que o objetivo de defesa dos preços internacionais das "commodities" seja alcançado.

\section{2. objetivo}

Apresentar um quadro analitico das negociações para implementação dos Acordos Internacionais de Cacau, Café e Açúcar e do comportamento do mercado internacional destes produtos, enfatizando as dificuldades de negociações e os efei tos dos respectivos acordos.

\subsection{Metodologia}

No presente estudo, serão analisadas as nego ciações dos Acordos Internacionais de Cacau, Café e Açūcar bem como a evolução do comércio internacional destes produtos no periodo 1962-1982.

Inicialmente apresenta-se uma retrospectiva his tórica das negociações para implementação dos Acordos Interna cionais de Cacau, Café e Açūcar. Procura-se destacar os principais objetivos e mecanismos propostos para a formalização destes Acordos, assim, como os pontos de maior divergência en tre paises produtores e consumidores cie cada produto. 0 mate rial bāsico utilizado sobre as negociações para implementação dos Acordos Internacionais de Cacau foram os trabalhos de Schutjer e Ayo (1967) e de Finlayson e Zachea (1983). Com re lação aos Acordos Internacionais de Café as informações bās í cas foram dos periödicos mensais da Fundação Getūlio Vargas - Conjuntura Econômica e Agroanalysis e sobre as negociações dos Acordos Internacionais de Açūcar foi utilizado o trabalho 
de Mont'Alegre (1976).

Em seguida analisa-se a evolução do mercado in ternacional de cacau, café e açūcar no período 1962-1982. A anālise do comércio internacional, baseia-se nas informações estatísticas de produção, exportação, consumo e preços de ex portação dos três produtos, procura-se enfatizar as modifica coóes ocorridas nestas variáveis, especialmente no caso do Bra sil, dado que o país é grande produtor e participa significa tivamente das exportações mundiais destes produtos.

Para o Brasil calcula-se a taxa geométrica anu al média de crescimento da produção (1962/63-1981/82), exporta ção e dos preços reais fob de exportação brasileira de cacau em amêndoas e derivados no período 1963-1982 (Tabela 05). A taxa geométrica anual média de crescimento da produção (1962) 63-1980), exportação e dos preços reais fob de exportação bra sileira de café cru em grãos e solúvel no período 1963-1981 (Tabela 15). A taxa geométrica anual média de crescimento da produção (1962/63-1981), exportação e dos preços reais fob de exportação brasileira de açūcar* e açūcar demerara no periodo 1963-1982 (Tabela 21).

Finalmente, para o cálculo do grau de concen tração das exportações brasileira de cacau em amêndoas, café cru em grãos e açūcar demerara no período 1963-1982, utiliza- se os dados referentes ao valor anual médio das exportaçóes brasileira por países importadores destes produtos (Tabelas 08 , 30 e apêndice 01). O cálculo através do indice degini deve-se ao fato desse indice, poder ser utilizado para medir o grau de concentração de qualquer distribuição estatística. Segun do HOFFMAN (1980), através de dois pares de valores acumulados

* Ver nota tabela 23 , pägina 97. 
de determinadas variáveis define-se pontos num sistema de ei xos cartesianos ortogonais, conforme figura 01 . 0 s pontos es tão sobre a Curva de Lorenz. Evidencia-se que quanto mais pon tos tivermos mais precisa será a medida de concentração.

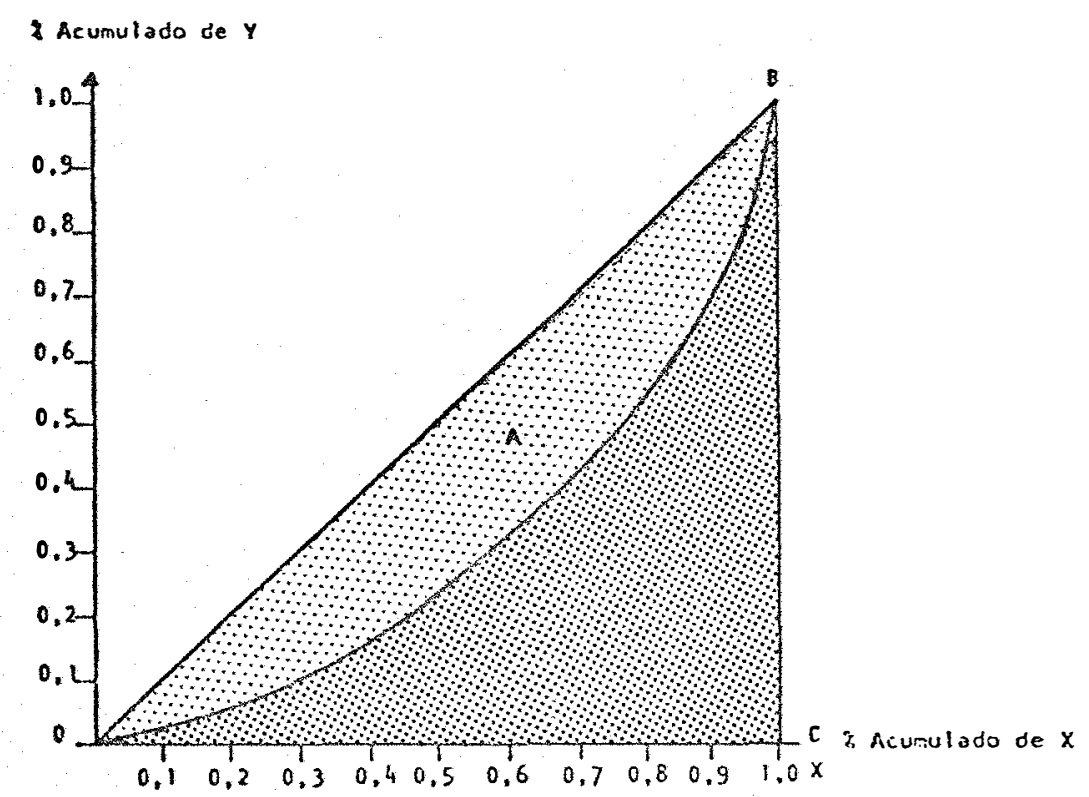

Figura 01 - Curva de Lorenz.

Na hipótese de uma perfeita igualdade tem-se $y=x$, isto é, ārea de concentração igual a zero. Portanto a "curva" de Lorenz da distribuição se reduz ao segmento de re ta (OB) na figura 01.

Na hipótese de o máximo de desigualdade, a àrea de desigualdade é praticamente igual à área do triângulo $(O B C)$ figura 01 , sendo numericamente igual a 0,5 .

a indice de Gini (G) por definição ē a relação entre a área de concentração, indicada por (A) e a ărea do triângul $O O B C$ : 
$G=\frac{A}{O B C} \rightarrow G=\frac{A}{0,5}=2 A$

Dado que $0 \leqslant A<0,5$, tem-se $0 \leqslant 6<1$.

0 uso do indice de Gini teve como objetivo ana lisar a concentração das exportações brasileira de cacau em amêndoas, café cru em grãos e açúcar demerara no período 19631982. Verifica-se as modificações ocorridas nos indices, e re laciona-se com as políticas adotadas pelo Governo brasileiro de incremento das exportações a partir de meados da década de 60, e com a política de industrialização brasileira a partir dos anos 70 .

No desenvolvimento do capitulo 03 , na medida do possivel, procura-se relacionar o comportamento do mercado internacional de cacau, café e açúcar, com a atuação dos respectivos acordos.

Os dados estatísticos de produção brasileirade cacau em amêndoas foram obtidos da publicação Gill and Duffus e do Quarterly Bulletin of Cocoa Statistics. As estatisticas de exportação brasileira de cacau em amêndoas e derivados são da publicação Comércio Exterior do Brasil - Banco do BrasilCACEX e os preços fob das exportações brasileira de cacau em amêndoas e derivados obteve-se dividindo o valor anual médio em dólar das exportações brasileira de cacau em amêndoas. e derivados pelo volume em toneladas das exportações brasileira destes produtos. 0s preços em dólar por tonelada das exporta ções brasileira de cacau em amêndoas e derivados foram deflacionados pelo indice de preço no atacado dos Estados Unidos corrigidos, base $1982=100$.

As informações estatísticas sobre produção bra 
sileira de café verde, exportação brasileira de café cru em grãos e solūvel foram obtidas do Anuärio Estatístico do Café 1976 e 1980/81-MIC-IBC. Os preços fob das exportações bras i leira de café cru em grãos e solúvel obteve-se dividindo o, va lor anual médio em dólar das exportações brasileira de café cruem grãos e solüvel pelo volume em toneladas das exportações brasileira destes produtos. Os preços em dölar por tonelada das exportações brasileira de café cru em grãos e solúvel fo ram deflacionados pelo indice de preço no atacado dos Estados Unidos corrigidos, base $1982=100$.

As estatisticas de produção brasileira de açū car foram obtidas do Relatörio Mensal-IAA-PLANALSUCAR e FAOProduction Yearbook. Os dados das exportações brasileira de açūcar e açūcar demerara obteve-se através do Departamento de Exportação-MIC-IAA e da publicação Comércio Exterior Brasil Banco do Brasil-CACEX. Os preços fob das exportações brasilei ra de açūcar e açūcar demerara obteve-se dividindo o valor anual médio em dólar das exportações brasileira de açūcar e açücar demerara pelo volume em toneladas das exportações bra sileira destes produtos. Os preços em dólar por toneladas das exportações brasileira de açūcar e açūcar demerara foram de flacionados pelo indice de preço no atacado dos Estados Uni dos corrigidos, base $1982=100$. 
2. HISTORICO

2.1. Acordos Internacionais de Cacau.

A produção mundial de cacau está concentrada principalmente em Gana, Nigēria, Costa do Marfim, República Unida de Camarões e Brasil, os quais respondem aproximadamen te por $80 \%$ da produção.

Os maiores países consumidores são os do conti nente europeu e Estados Unidos. Entre eles destacam-se Reino Unido, Alemanha Ocidental, Países Baixos, França, Itälia, Bél gica e Espanha.

E grande a importância do produto na geração de divisas para os países produtores. O Brasil exporta aproxi madamente $90 \%$ da produção brasileira de cacau, na forma de ca cau em amêndoas e derivados (manteiga de cacau, massa de ca cau ou líquor, torta de cacau e cacau em pö).

A lavoura cacaueira, como outros tipos de la vouras, convive com os efeitos de ciclo de preço. A frequente instabilidade de preço no mercado mundial de cacau desde a II Guerra Mundial, tem levado os países produtores e consumi 
dores de cacau a negociarem um Acordo Internacional de Cacau $(A \mid C)$ de maneira a administrar o mercado mundial do produto.

Em geral, as negociações do AlC têm se basea do em um tripé de medidas "uma faixa de preço mínimo e máxí mo, um sistema de cotas como medida suplementar de segurança da faixa de preços e da criação e manutenção de um estoque re gulador, que agiria como um agente interventor do mercado". 17

A instabilidade de preço ocasiona flutuação na receita de exportação de cacau dos países produtores, comgran des consequências econômicas e sociais para esses países, os quais são dependentes da receita de exportação de cacau. MENE ZES (1984).

As tentativas de negociação de um AlC para es tabilizar os preços tiveram início em 1956, sob a supervisão da Organização das Nações Unidas para Alimento e Agricultura (FAO). Foi criado, em junho de 1956, o Grupo de Estudo de Ca cau (GEC). Este grupo em novembro de 1956, se reuniu em Bruxé las pela primeira vez, com os representantes dos principais paises produtores e consumidores de cacau. Representando os países produtores estavam Brasil, Gana, Nigéria, República Do minicana, Equador e Suriname, os quais respondiam por $70 \%$ da produção mundial de cacau. Representando as nações consumido ras estavam Estados Unidos, Reino Unido, Alemanha, Holanda, França, Itälia, Austrälia, Bëlgica, Nova Zelândia e Suíça que somavam $82 \%$ das importações mundiais de cacau naquele ano.

A segunda reunião do GEC foi em Ibadan, na Ni gëria. Nas duas primeiras reuniões do GEC a discussão girou em torno da estabilidade de preço e teve como base o esquema

IJornal a Tarde (Bahia) 28 de novembro de 1981. 
do estoque regulador. o esquema do estoque regulador designa va que o gerente do Estoque entraria no mercado comprando ca cau quando o preço estivesse abaixo de um preço mínimo e ven deria cacau quando o preço estivesse acima de um preço máxi mo, preços estes a serem estabelecidos. O tema de maior desa cordo nesta reunião foi quanto ao financiamento de um fundo, para o estoque regulador entrar em operação. os países produ tores propuseram dividir os custos, as nações consumidoras não concordaram em contribuir com o financiamento para o fun do do estoque regulador. Assim, não houve um consenso entre paises produtores e consumidores de cacau.

Em maio de 1958, o GEC voltou a reunir-se em Hamburgo. Nesta reunião, duas propostas do esquema do estoque regulador foram apresentadas por Gana e Nigéria. A primeira proposta referia-se a uma contribuição no valor de $5 \%$ das ex portações e importações de cacau. Os recursos seriam administrados pelo gerente do estoque, o qual, entraria no mercado comprando cacau quando os preços declinassem e venderia cacau quando os preços aumentassem.

A segunda proposta era de ordem moral. No perío do de queda de preços os países produtores diminuiriam suas vendas de cacau e os países consumidores formariam maiores es toques. No período de alta de preços os países produtores co locariam no mercado todos os estoques e os países consumido res comprariam somente para o consumo corrente e não forma riam novos estoques. Os países consumidores argumentaram que os recursos propostos estavam aquem das necessidades e reafir maram a não concordäncia em contribuir para o financiamento do fundo do estoque regulador. Por outro lado, os países consu midores não acreditavam em um acordo moral, entre nações pro dutoras e consumidoras. Assim, as propostas foram rejeitadas. 
No ano safra $1958 / 59$ os preços de cacau foram considerados relativamente estáveis em torno de US $\not<36 / 1 \mathrm{~b}$, mas, a partir de outubro de 1960, voltou a instabilidade de preços. Foi criado então o Grupo de Trabalho para Estabilização de Preços (GTEP), que reuniu-se em fevereiro de 1961 para avali ar a situação do mercado mundial de cacau e estimar oferta e demanda para alguns anos. Foi sugerido pelo grupo de traba Iho a adoção de um esquema de cota de exportação, cuja propos ta foi analisada pelo GEC em Accra, em abril de 1961.

Em outubro de 1961 o texto voltou a ser discu tido e analisado. o texto propunha um acordo para um período de três anos, com a adoção do esquema de cota de exportação juntamente com um mecanismo de sustentação de preço. 0 Acor do deveria ser administrado pelo Conselho Internacional do Cacau ( $C \mid C)$, o qual teria as seguintes atribuições:

- criação de um fundo internacional do cacau, para a promoção do consumo do produto, assistência aos paí ses produtores, garantindo os estoques sobre as cotas de ex portação destes países;

- divulgação dos dados referentes à produção de cada país produtor;

- estabelecimento do montante de cacau que po deria ser importado dos países não membros e o volume dos e toques que seriam administrados pelo fundo do cacau.

O esquema de cota de exportação com um mecanis mo de sustentação de preço funcionaria com um preço máximo e um preço mínimo. Quando o preço do cacau declinasse, o clc reuniria-se para determinar o nivel de preço, para o qual, f xaria o sistema de cota. Se o preço declinasse ainda mais, o CıC decidiria sobre a redução da cota de exportação. Contrariamente, se o preço do cacau aumentasse, o CIC reuniria-se 
para determinar o nível de preço, a partir do qual os países exportadores deveriam avaliar seus estoques e as necessidades do mercado.

Os países produtores não concordaram com o es quema de cota de exportação como mecanismo de sustentação de preço, argumentando que não era adaptāvel ao cacau. Eles eram a favor de cota de venda, pois esta teria influência imedia ta nos preços de cacau. Os países consumidores eram a favorde um preço limite ao invés de um preço de sustentação.

Na quinta reunião do GEC, em maio de 1962, fo ram discutidas três propostas para a. cota de venda. A prime ra foi preparada por Brasil, Gana e Nigéria, a segunda pelo presidente do Grupo de Trabalho-GT e a terceira pelo Reino Unido, SCHUTJER e AYO (1967). Na segunda propostaforam inclui dos muitos pontos de vista discutidos em reuniões anteriores, por paises produtores e consumidores. A terceira proposta era uma combinação de cota de exportação e de venda.

Foi designado um grupo de trabalho constituído por cinco dos maiores paises produtores que representavam $75 \%$ da produção mundial de cacau e cinco maiores países consumido res que somavam $80 \%$ das importações mundiais de cácau, parade linear um texto sobre o Acordo, baseado nas três propostas, o qual seria apresentado na Conferência de Negociação.

o texto foi revisado na reunião em Roma, em setembro de 1962, e posto novamente para anälise na sexta reu nião em Porto Espanha em março de 1963. 0 texto incluia a organização Internacional do Cacau (licco) e o Conselho Interna cional do Cacau (CIC). A l CCO funcionaria através do CIC e a duração do Acordo poderia ser de três a cinco anos. A cota de venda para cada país deveria ser uma proporção uniforme da co 
ta bāsica. Os ajustamentos do nível de cota de venda anual se riam feitos pelo.ClC, de acordo com as mudanças na demanda.

Na Conferência de Negociação de 26 de setembro a 24 de outubro de 1963, a discussão central foi sobre o ní vel de preço a ser fixado para o cacau. As nações produtoras, I ideradas por Gana, propunham preços Iimites de US $\not 31,25 / 1 b-$ US $\not 43,75 / 1 b$. Os países consumidores não concordaram e argu mentaram que havia um relativo excesso de oferta de cacau no mercado e que um preço mínimo de US $\not 25 / 1 b$ seria mais conveni ente. Para eles um preço mínimo de US $\not 31,25 / 1 b$ poderia levar ao uso de substitutos de cacau e da manteiga de cacau. os paí ses consumidores sugeriram preços entre US $\not 25 / 1 b$ e, US $\not 24 / 1 b$, mas os países produtores recusaram a proposta e sugeriram um preço mínimo de US $\not 33 / 1 b$.

Outro tema de discussão foi o preço de inter venção. Os países produtores sugeriram um preço de interven ção de US $\not 27 / 1 b$ e os consumidores um preço de US $\not 19 / 1 \mathrm{~b}$. Em seguida, os países consumidores sugeriram um preço de intervenção de US $20 / 1 b$, mas os representantes dos países produ tores insistiram num preço de $U \subseteq \not 27 / 1 b$.

Em maio de 1962 foi instituída a Aliança dos Países Produtores de Cacau, formada por cinco maiores países produtores de cacau, Gana, Nigéria, Brasil, Costa do Marfim e Camarões. A Aliança propunha um esquema de estabilização de preço no mercado mundial de cacau.

Na reunião de maio de 1964, foi proposto pelos países produtores de cacau pertencentes à Aliança, um acordo para estabilização de preço. 0 Acordo assumia que o crescimen to da produção a taxas mais elevadas que as do consumo era a causa do declínio dos preços do produto, SCHUTJER e AYO (1967). 
Desta maneira, o acordo delineado para regular o mercado, se ria através do controle da oferta de cacau no mercado interna cional.

Os membros da Aliança dos Países Produtores de Cacau tentaram, por diversas vezes, retirar-se do mercado e reduzir a cota de exportação com objetivo de aumentar os pre ços do cacau, mas essas tentativas culminaram em fracasso, uma vez, que havia excedente de produção no mercado internacional. Desta maneira, os esforços dos países produtores para estabi lização de preços não surtiram efeitos.

As principais razões para o fracasso do Acordo entre os países produtores foram:

- "discordância e deslealdade entre alguns dos membros da Aliança"; e

- "suspeita dos países consumidores quanto ao sucesso do Acordo", SCHUTJER e AYO (1967).

A primeira razão está relacionada com a depen dência econômica de alguns membros da Aliança com grandes paí ses consumidores. A segunda, refere-se à crença dos países con sumidores no fracasso do Acordo, devido a fatores como o mé todo adotado para a alocação de cotas de venda, condições não apropriadas de estocagem nos países produtores e a falta de habilidade dos países produtores em limitar a produção de ca cau, dada a dependência econômica desses países das exporta ções do produto.

0 GT reuniu-se em outubro de 1965, para discu tir as medidas de curto prazo recomendadas pelo Comitê de "commodities" das Nações Unidas. A principal discussão foi so bre a possibilidade de fixação de um preço mínimo para o ca 
cau no período 1965-1966. Gana considerou razoável um preço minimo de US\& $24 / 1 b$ mas, os países consumidores rejeitaram a proposta.

outras medidas de curto prazo foram discutidas pelo GT. A criação de um fundo de emergência para o qual, con tribuiriam os governos nacionais e agências financeiras inter nacionais, que forneceriam empréstimos aos países produtores, para a retirada de oferta no mercado do cacau, a possibilidade de aumentar as exportações para os países do leste europeu, remoção de todas as tarifas que inibissem as importações e consumo de cacau em amêndoas e seus derivados, pelos países desenvolvidos.

Em janeiro de 1966, em Nova lorque, novamente - GT reuniu-se para discutir o esquema do estoque regulador a travēs de cota de venda, SCHUTJER e AYO (1967).

Em maio de 1966, o GT apresentou um texto no qual incluía um preço limite, cota de venda, administração do estoque regulador e a utilização do excedente de cacau para uso não tradicional, SCHUTJER e AYo (1967).

Na segunda Conferência de Negociação do Cacau, de 24 de maio a 23 de junho de 1966, em Nova lorque, o ponto principal da discussão foi o estabelecimento de um preço limi te e um preço mínimo mundial, mas os países produtores e consumidores não chegaram a um consenso, SCHUTJER e AYO (1967).

Em maio-junho de 1967, Gana e Estados Unidos, respectivamente grande país produtor e maior consumidor de ca cau, reuniram-se para discutir o esquema do futuro $A / C$, o qual se baseava nos preços 1 imites de US $\notin 20 / 1 b$ e US $\not 29 / 1 b$, com ajustamento de cotas para equilibrar o mercado. Em outu 
bro de 1967, os dois países citados e outros doze importantes paises produtores e consumidores de cacau assinaram um memo rando püblico baseado nos entendimentos bilaterais entre Gana e Estados Unidos, FINLAYSON e ZACHEA (1983).

Na Conferência das Nações Unidas, em dezembro de 1967, em Genebra, supunha-se que os países produtorese con sumidores de cacau chegariam a um acordo, principalmente devi do ao início de um consenso em outubro, através do memorando público, mas, os representantes dos países produtores e consu midores novamente não conseguiram formalizar o acordo.

Em junho de 1970 nova tentativa foi feita para implementação do AlC. Sete países consumidores e produtores su geriram que quatro fatores poderiam ser negociados em um acor do: $\underline{2} /$

- flutuações de preços;

- garantia de oferta a preços razoāveis;

- facilitar a expansão da produção; e

- incrementar a receita de exportação, contraba lançando com as necessidades dos países consumidores.

A intransigência de ambos os lados, países pro dutores e consumidores, fez com que por longo período, a im plantação do acordo fosse adiada. Assim, o 1 o AlC foi institu ido apenas em 20 de outubro de 1972, fara um período de três anos. Participaram desse acordo 63 países, entre produtores e consumidores, representando mais de $90 \%$ da produção mundial e aproximadamente $70 \%$ do consumo mundial de cacau, com a ex clusão dos Estados Unidos, maior consumidor mundial.

2 I International Federation of Agricultural Producers (1972) 
0 Acordo tinha como objetivos: disciplinar as flutuações de preços que afetam a economia cacaueira a curto e longo prazo; incentivar uma comercialização adequada do pro duto para manter e assegurar a receita cambial dos países, ex portadores de cacau; garantir o abastecimento a preços compativeis para os países consumidores; incentivar o crescimento do consumo e, se necessário, da produção, de modo a ajustarno médio e longo prazo o equilíbrio entre a oferta e demanda, CE PLAC (1973).

019 Alc baseou-se em um tripé de medidas:

- um sistema de preços máximo e mínimo;

- um sistema de cotas de exportação, com meca nismo de ajuste de cotas; e

- um estoque regulador com capacidade de 250 mị toneladas.

Os preços negociados no acordo, foram um pre

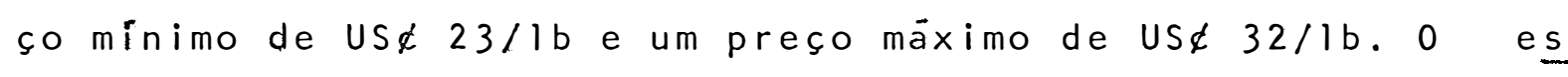
toque regulador, com capacidade de $250 \mathrm{mil}$ toneladas, seria financiado atravēs de US $\notin 1 / 1 \mathrm{~b}$ sobre as exportações e importa ções de cacau, CEPLAC (1973). Se a quantidade de cacau estoca da excedesse as $250 \mathrm{mil}$ toneladas, o excedente seria destinado a uso não tradicional (Artigo 45 do AlC, 1973).

os países produtores membros tinham proteção, pois era limitado o montante de cacau importado dos países pro dutores não membros. Por outro lado, os países exportadores da riam preferência aos importadores quando os preços de mercado excedessem opreço mäximo, FINLAYSON e ZACHEA (1983).

Foi estipulado que o preço das amêndoas de ca cau seria determinado em relação a um preço diário e a um pré 
ço indicativo (Artigo 28 do AIC, 1973). "O preço diário de cacau em amêndoas é a média das cotações futuras durante os três meses ativos mais próximos na Bolsa de Cacau de Nova lor que, ao meio dia, e na Bolsa de Londres na hora do fechamento. os preços de Londres se convertem em centavos de dólar dos Es tados Unidos por libra utilizando a taxa de câmbio vigente pa ra os seis meses futuros publicado em Londres na hora do fe chamento. A passagem para o período dos três meses seguintes se efetua no dia 15 do mês que precede o mês ativo mais próxi mo em que os contratos vencem".

"O preço indicativo é a média dos preços dià rios estabelecida com base num período de 15 dias ūteis conse cutivos, ou para os fins do parágrafo 49 do artigo 34, num período de 22 dias úteis consecutivos". CEPLAC (1973).

As cotas básicas eram estabelecidas consideran do o volume produzido de cacau de cada país exportador, duran te as três ültimas safras. Quando ocorresse variação no preço indicativo, mudava-se a cota de exportação dos países membros. As cotas básicas iniciais do AlC de 1972, foram baseadas nas grandes safras anuais dos países membros desde 1964/65. Os países que produziam menos de $10 \mathrm{mil}$ toneladas e principalmen te cacau fino, estavam isentos de cotas.

No entanto, o AlC de 1972 não atuou devido ao fato dos preços internacionais de cacau terem permanecidos aci ma das faixas de preços previstas e também por não existirem estoquesacumulados para disciplinar o mercado.

Em agosto de 1973, o Conselho de Cacau se reu niu, e os países produtores queriam um aumento de $20 \%$ nos pre ços limites. os países consumidores não concordaram, alegando que não sabiam como seria o comportamento do mercado no futuro. 
0s preços continuaram a aumentar e, em setembro de 1974 , países produtores e consumidores concordaram em aumentar os preços para um preço mínimo de US $\not 29,5 / 1 b$ e um preço māximo de US $\not \subset 38,5 \% 1 \mathrm{~b}$.

Em 1975 tiveram início as negociações para um novo AIC. O Secretārio da UNCTAD na época, disse que os pre ços limites deviam ser fixados de acordo com a tendência do mercado, o que foi compartilhado por vários países produtores. Costa do Marfim, Nigëria, Camarões e Togo argumentaram que o preço māximo, a ser determinado, devia basear-se na média dos preços diários dos ültimos três anos. os representantes dos países consumidores não aceitaram a proposta e argumentaram que os últimos três anos não eram considerados um período nor mal, FINLAYSON e ZACHEA (1983).

Os Estados Unidos voltaram à participar das negociações do AlC de 1975. Eles propunham somenteo mecanismo do estoque regulador para defesa dos preços e se opunham à có ta de exportação, ao contrário de todos os outros membros par ticipantes.

A questão de preço foi negociada e o preço má ximo foi fixado em US $\$ 55 / 1 b$ e o mínimo em US $\not 39 / 1 b$. O AlC de 1975 dava menos ênfase à cota de exportação e mais ênfase ao mecanismo do estoque regulador, FINLAYSON e ZACHEA. (1983).

A Costa do Marfim considerou inadequados os preços limites fixados e a divisão da cota básica, argumentan do que o rảpido crescimento da produção e os planos de expansão da produção de cacau não tinham sido considerados na de terminação das cotas básicas, as quais foram baseadas na mé dia de produção dos anos 1969/1970-1973/1974. A despeito de inūmeras divergências, 0 AlC de 1975 foi ratificado em setembro de 1976. 
No 29 AlC, os objetivos e mecanismos para está bilização de preços eram praticamente os mesmos determinados no 19 AlC de 1972. Em outubro de 1977, o Conselho concordouem aumentar os preços limites para US $\not 65 / 1 b$ e US $\not<1 / 1 b$. Da mes ma maneira que o AlC 1972, o 29 AlC não entrou em operação, de vido aos preços no mercado internacional terem permanecidos a cima dos preços limites fixados e pela excassez de oferta no mercado internacional de cacau. A situação prevalecente de al ta de preços do cacau, de 1972 até o início de 1980, refletia a escassez do produto no mercado.

De janeiro a fevereiro de 1979 foi realizada a 1 ạ reunião da Conferência de Negociação, onde os países produ tores atacaram a idéia dos Estados Unidos de ajustar os pre ços limites para baixo quando as condições do mercado o exi gissem. Eles insistiram na manutenção da cota de exportação no novo Acordo. A maior divergência entre produtores e consumidores de cacau nesta Conferência, foi quanto ao nível de preços limites, fixado para o 39 AlC. $0 s$ produtores inicialmente eram a favor de um preço limite de US\$1,86/1b, US\$ $2,26 / 1 b$ e uma faixa de não intervenção de US\$2,01 - US\$2,11 $11 \mathrm{~b}$. Os países consumidores propuseram um preço limite de US $\not$ $69 / 1 b$ e US $\$ 1,16 / 1 b$ e uma faixa de não intervenção de US $\not$ $74 / 1 b$ - US $\$ 1,11 / 1 b$. Dada a grande diferença no nível dos pre cos propostos, países produtores e consumidores não chegaram a um acordo, FINLAYSON e ZACHEA (1983).

Uma nova negociação foi tentada em agosto de 1979, quando o preço de mercado tendia a decrescer. Nesta opor tunidade o Embaixador da Jamaica propós um preço limite de US $1,05 / 1 b$ e US $1,75 / 1 b$ e uma faixa de não intervenção de US $\$ 1,12 / 1 \mathrm{~b}$ e US $\$ 1,68 / 1 \mathrm{~b}$. Os países produtores não se opuse ram. Os países consumidores acharam que o preço mínimo de in tervenção estava alto e propuseram um preço limite de US\$ 
$1,03 / 1 b$ e US $\$ 1,67 / 1 b$, com uma faixa de não intervenção entre US $\$ 1,10 / 1 \mathrm{~b}$ e US $\$ 1,6.0 / 1 \mathrm{~b}$. Os Estados Unidos argumentaram que a expectativa de excesso de produção de cacau nos próximos anos era evidente, assim, o preço mínimo de intervenção não deveria ser acima de US\$1,00/1b. Camarões, Costa do Marfim e Nigëria consideraram o preço de US\$ 1,10 muito baixo. Novamen te não foi possivel um consenso entre os países, FINLAYSON e ZACHEA (1983).

Em novembro de 1979, em Genebra, os países pró dutores e consumidores de cacau, reiniciaram as negociações do 39 AlC. A capacidade do estoque regulador seria de $250 \mathrm{mil}$ to neladas e por um voto especial do Conselho de Cacau seria au mentado para $350 \mathrm{mil}$ toneladas, FINLAYSON e ZACHEA (1983). Os paises produtores insistiram para que fosse implantado o sistema de cota de exportação, e rejeitaram a proposta dos Esta dos Unidos de ajustar os preços limites baseado nas variacões da capacidade do estoque regulador. A maior dificuldade das ne gociações era quanto ao nível de preços limites. os países pro dutores propuseram US $1,20 / 1 b$ e US $1,66 / 1 b$ e os países con sumidores eram a favor de US\$1,00/1b e US\$1,46/1b. A falta de consenso entre os países, fez com que as negociações fos sem adiadas até março de 1980 .

0 colapso das negociações levou os países produtores a uma ação unilateral, para regular e estabilizar os preços do mercado. Em dezembro de 1979 foi formado o Grupo de Abidjan, liderado por Brasil e Costa do Marfim e incluindo Ga na, Camarões, Nigēria, Togo, Equador e outros. Os membros não venderiam cacau quando os preços estivessem menores que US\$ $1,50 / 1 b$. Os países produtores deveriam retirar uma parte doca cau do mercado para os meses futuros, de maneira a garantir o preço mínimo. A Costa do Marfim estoccu $100 \mathrm{mil}$ toneladas de cacau, o que não foi seguido pelos demais países. Assim, o 
pacto do Grupo de Abidjan fracassou, o que mostra a falta de união entre países produtores, principalmente em condições de expansão da produção e excesso de oferta, FINLAYSON e ZACHEA $(1983)$.

As diversas tentativas de negociações para im plementação de 3 ? Alc culminaram em fracasso, decorrente da radicalização de alguns países consumidores, entre eles o prin cipal importador mundial de cacau, os Estados Unidos, e da imprecisão dos países produtores de cacau na condução da poli tica conjunta.

A maior divergência nas negociações do 3 ? AlC, entre países produtores e consumidores, referia-se à fixação dos preços máximo e mínimo. A relutância por parte dos países produtores a aceitar o preço proposto pelas nações consumidoras, a previsão de excedente des estoques de cacau e a relati va estagnação do consumo, fizeram com que os preços do produ to no mercado mundial decrescessem.

A ocorrência de excedente de produção no in cio da dēcada de 1980 e a não entrada em vigor do 39 Alc, con tribuíram para a continuidade da queda de preços do produto.

Finalmente, na Conferência de Cacau das Nações Unidas, em novembro de 1980, foi concluído o 39 AlC, embora sem as adesões da Costa do Marfim, maior produtor mundial de cacau e Estados Unidos, maior importador mundial.

os objetivos do 39 Alc permaneceram os mesmos dos dois Acordos anteriores. 0 39 AlC baseou-se em um sistema de preços máximo e mínimo, preços de intervenção e um estoque regulador com capacidade de $250 \mathrm{mil}$ toneladas. 
os niveis de preços estabelecidos foram um pre ço máximo de US\$1,60/lb e um preço mínimo de US\$ $1,00 / 1 b ; 0$ preço inferior de intervenção foi fixado em US\$ $1,10 / 1 b$ e o māximo em US $1,50 / 1 b$. Em setembro de 1982 os preços de inter venção foram fixados em um mínimo de US\$1,06/1b e um mäximo de US\$1,46/1b.

As operações do estoque regulador seriam finan ciadas pelos países produtores e consumidores, os quais contribuiriam com US $\$ 1,00 / 1 b$ sobre as exportações e importações de cacau.

0 estoque regulador do 39 A IC deu início às suas operações de compras em 19 de outubro de 1981 para "enxu gar" o mercado e dar suporte ao preço mínimo de US $\$ 1,10 / 1 b$, mas, o objetivo não foi alcançado, dado os volumosos estoques existentes e os limitados recursos do estoque regulador.

Na reunião do Conselho e do Comitê Executivo da ICCO, realizada em Londres no período de 16 a 20 de novem bro de 1981, foi analisada a proposta de financiamento do es toque regulador para que este continuasse sua intervenção no mercado. o gerente do Estoque Regulador foi autorizado a nego ciar empréstimos no valor māximo de 120 milhões de dólares, CEE PLAC (1981).

De 25 a 29 de janeiro de 1982, na reunião do Comitê Executivo e do Conselho da lcco, foi formalizado o fi nanciamento de $75 \mathrm{milhões} \mathrm{de} \mathrm{dölares} \mathrm{atravēs} \mathrm{de} \mathrm{três} \mathrm{bancos}$ brasileiros (Banco do Brasil, Banco Econômico e Banco do Esta do de São Paulo), ao estoque regulador de cacau. Nestareunião foi também aprovado o aumento da taxa de contribuição do fun do do estoque regulador de US $\notin 1,00 / 1 \mathrm{~b}$ para US $\notin 2,00 / 1 \mathrm{~b}, \quad$ a partir de 19 de outubro de 1982, CEPLAC (1982). 
No período de 13 a 22 de julho de 1983, em Lon dres, na reunião do Conselho e do Comitê da lcco, os países produtores e consumidores de cacau decidiram que o gerente do estoque regulador não interviria no mercado, com o propósito de defender os baixos preços do cacau, devido a curta vigên cia que ainda restava para o 3 ? AlC. Assim, o emprēstimo de 75 milhões de dölares a ser feito junto aos bancos brasile ros não seria utilizado, CEPLAC (1983).

A partir de outubro de 1983 tiveram inicio as negociações para implementação do 40. AlC. Na tentativa de al cançar os objetivos do Acordo, os membros participantes ten tam adotar medidas com o fim de manter os preços de cacaumais pröximos possíveis do preço suporte a ser fixado conforme às disposições do Acordo. Dentre os principais mecanismos a se rem adotados, estão, a instituição de um estoque regulador e um sistema de cota de exportação. A capacidade do estoque re gulador passaria de $250 \mathrm{mil}$ toneladas para $350 \mathrm{mil}$ toneladas, sendo o estoque regulador básico de $100 \mathrm{mil}$ toneladas e o adi cional de $250 \mathrm{mil}$ toneladas. $3 /$ Até o momento países produto res e consumidores não chegaram a um consenso para implementa ção do 4ọ Acordo Internacional do Cacau.

\subsection{Acordos Internacionais de Café}

O café é um dos principais produtos agrícolas no comércio internacional e fonte de divisas para a maioria dos paises produtores em fase de desenvolvimento.

Os maiores países produtores de café são Bra

3/ International Cocoa Organization - Draft Economics Provisions of Fourth International Cocoa Agreement - Outubro de 1983. 
sil, Colómbia, Costa do Marfim, El Salvador, México, Costa Rí ca e Uganda, sendo que mais de $85 \%$ da produção mundial de ca fé é proveniente dos países latino-americanos.

Os Estados Unidos e países da Comunidade Econô mica Européia-CEe importam aproximadamente $90 \%$ do café mundi al, sendo os maiores consumidores mundiais de café.

Até meados da década de 60 o comércio internacional brasileiro era práticamente sustentado pelas exporta ções de café.) o café portanto, constituía-se no principal pro duto gerador de divisas para o país. No periodo analisado ... (1963-1982) constata-se que as exportações brasileira de ca fé em 1963-1964, representavam mais de 50\% do valor das expor tações totais do Brasil. A partir de 1965 a participação do café vem decrescendo, em especial, na década de 70 . Este de créscimo, deve-se à mudança na política brasileira de comér cio exterior, VEIGA (1974), influenciada pela conjuntura internacional de aumento de preşos das "commodities", No entan to durante a década de 70 o café manteve em média uma partici pação em torno de $19 \%$ do valor total das exportações brasilei ra. (Tabela 01 ).

A importância do café, como gerador de divisas para propiciar o crescimento e desenvolvimento das economias menos desenvolvidas, levou à preocupação de manter os preços do produto estáveis. Nos anos anteriores à 11 Guerra Mundial, houve diversas tentativas para implantação de um acordo entre paises produtores de café, sem que se chegasse a um consenso entre a maioria dos países. Com o inicio do conflito bélico, as exportações latino-americanas reduziram-se assustadoramente. O excesso de oferta de café ocasionou queda nas cotações no mercado internacional. Desta maneira, em junho de 1940, em Nova lorque, reuniu-se a 111 Conferência Pan-Americanado Café. 


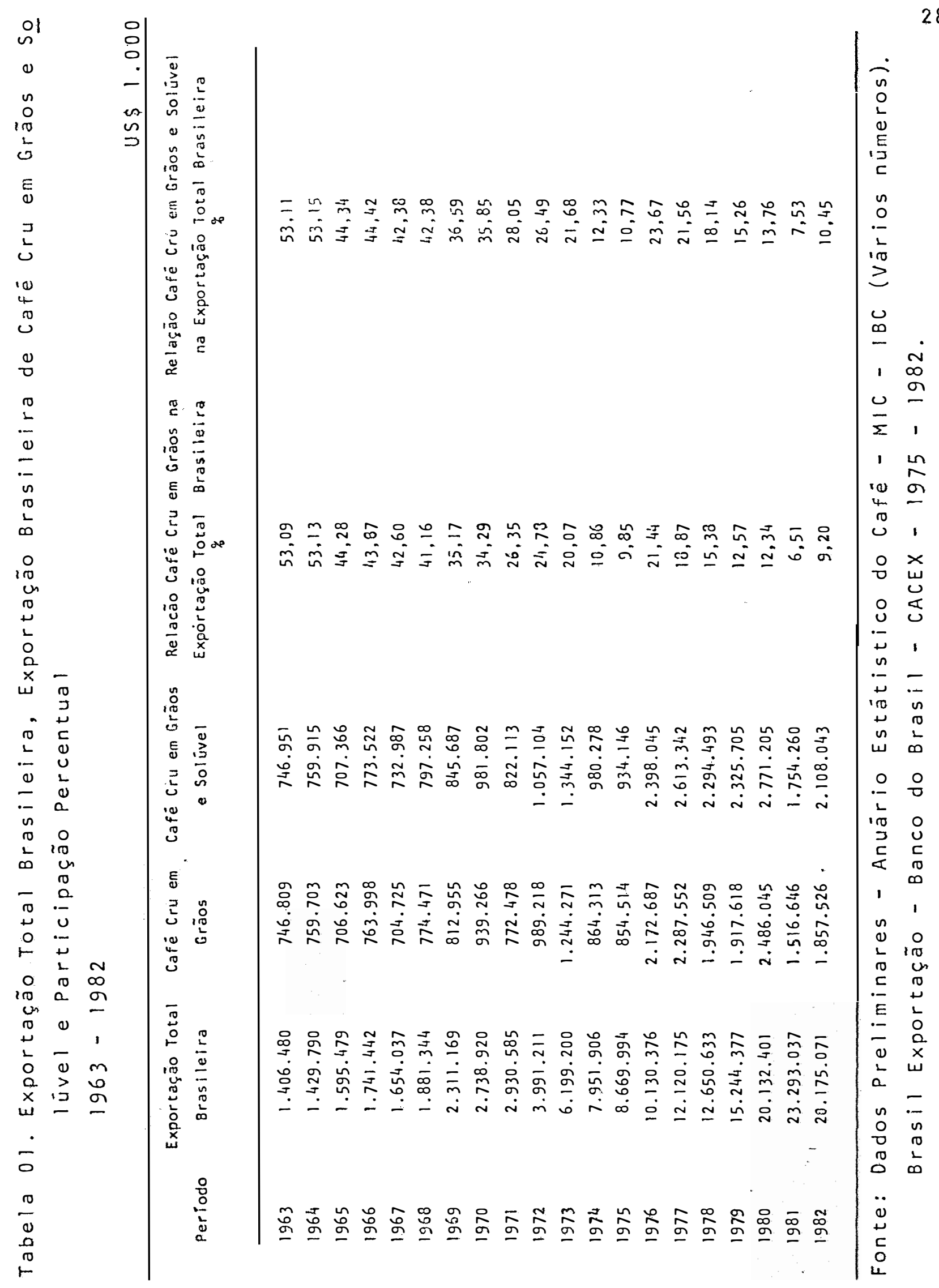


Foi sugerida a adoção de cota de exportação para os Esta dos Unidos e outros países consumidores. A proposta foi apro vada em 28 de novembro de 1940, e o acordo denominado de Acor do Interamericano do Cafél. 0 acordo teria duração de três anos podendo ser prorrogado por mais três anos. os preços logo ini ciaram a escalada de aumento, embora administrados pelos Es tados Unidos. Este país, tinha como objetivo assegurar o forne cimento do produto a médio e longo prazo.

Apōs 1945, retorna a crise na cafeicultura, com excesso de produção e declínio dos preços do produto. A par tir dessa época, foi reconhecida a necessidade de entendimentos bilaterais entre países produtores e consumidores para es tabilização do mercado.

Apesar do empenho do Brasil nos anos que se su cederam, as negociações não lograram êxito. A expectativa da super safra de 1958-1959 levou a novas oscilações dos preços do café. Assim, em 18 de outubro de 1957 foi assinado na cida de do México, um convênio para regular as exportações, chamado Convênio do México, entre Brasil, Colómbia, Costa Rica, El Salvador, Guatemala, México e Nicarágua. O Convênio durou um ano e, de alguma forma, deu suporte às cotações, não sendo en tretanto, suficiente para sustentar os preços, dada a super produção mundial de café que se configurava.

Os Estados Unidos resolveram liderar e patro cinar um acordo entre os países produtores de café, na tenta tiva de frear o declínio dos preços. Foi assinado em Washington, em 27 de setembro de 1958, o Acordo Internacional do Ca $f \bar{e}$, do qual faziam parte somente quinze paises produtores la tino-americanos. Este acordo, como o do México, baseou-se em cota de exportação. 
Nos anos seguintes continuou o empenho para a formalização de um acordo entre países cafeicultores e consumidores. Como os demais produtos, o café vinha enfrentando su cessivas crises e sūbitas quedas de preços. A situação se agra vou a partir de 1962, em consequência do excesso de oferta no mercado mundial e da formaçäo de volumosos estoques em diver sos países produtores.

Em outubro de 1962 foi implantado o 19 Acordo Internacional do Café entre países produtores e consumidores, com os seguintes objetivos:

- "alcançar um equilibrio razoável entrea ofer ta e a procura de café, em bases que assegurem fornecimentos adequados aos consumidores e mercado para o café, a preços equitativos, aos produtores, e que resultem, a longo prazo, no equilibrio entre a produção e o consumo"';

- "minorar as sērias dificuldades causadas por onerosos excedentes e excessivas flutuações de preços de café prejudiciais tanto a produtores como a consumidores";

- "contribuir para o desenvolvimento dos recur sos produtivos para elevar e manter os níveis de emprego e de renda nos países membros, estimulando, desse modo, a obtenção de salärios justos, padrões de vida mais elevados e melhores condições de trabalho";

- "ajudar a elevar o poder aquisitivo dos paises produtores de café pela manutenção dos preços em niveis equitativos e pelo incremento do consumo"';

- "estimular o consumo de café por todos os

meios possiveis"; e

- "em geral, reconhecendo a relação entre o co mércio do café e a estabilidade econômica dos mercados de pro dutos industriais, incentivar a cooperaça internacional com 
respeito aos problemas mundiais do café".

o Acordo tinha como principal mecanismo de es tabilização de preços, um esquema de cota que previa o ajusta mento automático a partir de uma determinada faixa de preço.

As geadas que ocorreram no Brasil, a partir de agosto/setembro de 1963, ocasionaram elevação nos preços do café, notadamente no ano de 1964, quando os preços passaramde US\$ 638 por tonelada, para US\$ 847, (Tabela 02). o incremento das cotações levaram o governo dos Estados Unidos a propor o aumento das cotas de exportação para o mercado voltar à norma lidade, uma vez que não havia excassez do produto, mas sim, déficit na safra brasileira de café verde, em consequência de condições climáticas adversas.

Durante os anos do Acordo, os negócios do café estiveram continuamente afetados por fatores tais como: a mo rosidade do Senado norte-americano para aprovar a implantação do Acordo Internacional do Café naquele país, o qual só foi ratificado em 1963; e a greve dos estivadores dos portos do Atlântico e do Golfo do México que terminou no inicio de 1965.

Em maio de 1965 foram aprovadas, pela Organiza ção Internacional do Café, duas propostas feitas pelo Brasil. A primeira referia-se ao ajustamento automático da cota de ex portação com relação ao nível de preço vigente no mercado. A segunda propunha a formação de um fundo de financiamento aos paises produtores com grandes estoques de café, com o objeti vo de reduzir a oferta e aumentar os preços do produto.

No periodo de 1962-1968 a situação prevalecente no mercado mundial de café de volumosos excedentes de pro dução e a redução relativa do consumo per-capita de café nos 
Tabela 02. Preços Médios das Exportações Brasileira de Café $1963-1981$

$U S \$ / t$

\begin{tabular}{lccc}
\hline & Café Cru em Gräos & & \\
Periodo & Solüvel & Café Cruem Gräos & Café Solüvel \\
\hline 1963 & 638 & 637 & 1.731 \\
1964 & 847 & 847 & 1.723 \\
1965 & 874 & 873 & 831 \\
1966 & 757 & 756 & 799 \\
1967 & 705 & 701 & 796 \\
1968 & 698 & 699 & 658 \\
1969 & 719 & 725 & 591 \\
1970 & 958 & 975 & 680 \\
1971 & 745 & 746 & 712 \\
1972 & 917 & 942 & 660 \\
1973 & 1.131 & 1.161 & 848 \\
1974 & 1.233 & 1.264 & 1.041 \\
1975 & 1.066 & 1.093 & 846 \\
1976 & 2.562 & 2.697 & 1.724 \\
1977 & 4.274 & 4.431 & 3.422 \\
1978 & 3.047 & 3.132 & 2.641 \\
1979 & 3.228 & 3.411 & 2.576 \\
1980 & 3.062 & 3.169 & 2.361 \\
1981 & 1.832 & 1.837 & 1.794 \\
\hline & & & \\
\hline
\end{tabular}

Fonte: Dados Preliminares - Anuário Estatístico do Café MIC - IBC (Vàrios números).

Brasil Exportação - Banco do Brasil - CACEX - 1975 1982 . 
Estados Unidos, contribuíram para as frequentes quedas de pre. ços do produto. Os preços não caíram a níveis "críticos" de vido à atuação do Acordo Internacional do Café e à defesa fei ta pelo Brasil de redução de suas exportações. Adicionalmente - Brasil, dava prosseguimento ao plano de erradicação e diver sificação da cultura, iniciado em 1962.

o Brasil, mesmo exportando um volume reduzido de café para garantir os preços no mercado mundial, enquanto os demais países produtores colocavam a quase totalidade de suas safras à venda, beneficiou-se com a implantação do Acor do Internacional do Café, uma vez que a colocação do produto no mercado internacional pelos concorrentes, estava de certa forma, sendo controlada.

No início de 1968 começaram as negociações pá ra a renovação do Acordo Internacional do Café. Os principais itens negociados foram: fixação das cotas básicas de exporta ção entre os países membros e ajustamento das cotas com rela ção ao comportamento dos preços no mercado; medidas disciplinares da produção e do nível dos estoques; estabelecimento de um Fundo de Diversificação; tarifas preferenciais da Comunida de Econômica Européia aos países africanos; e a exportação de café industrializado do Brasil para os Estados Unidos.

0 ajustamento das cotas de exportação estavare lacionado ao movimento dos preços dos principais tipos de ca fé (arábicas suaves colombianos; outros aräbicas suaves, arábicas não lavados e robustas) 4 . Quando da necessidade da re dução das cotas de exportação de algum grupo, estas seriam re duzidas no mäximo em $5 \%$ das respectivas cotas anuais. 0 Con selho da organização Internacional do Café tinha poder para

4/Também denominados colombianos, centrais, brasileiros e africanos, respectivamente. 
f:ixar diferenciais de preços e faixas de preços para os dife rentes tipos de café, levando em consideração o comportamento futuro dos preços no mercado.

Quanto ao disciplinamento da produção, os membros produtores se propunham a produzir um volume de café com patível com às necessidades de consumo interno, externo e a capacidade dos estoques.

o Fundo de Diversificação foi instituído com o objetivo de racionalizar a produção de café e equilibrar ofer ta e demanda no mercado mundial de café.

As discussões sobre às tarifas preferenciais a dotadas pela CEE aos países africanos, salientavam a necessidade da redução ou eliminação das barreiras prejudiciais ao aumento do consumo de café.

o impasse, com relação à exportação de café in dustrializado do Grasil para os Estados Unidos, só foi solucio nado em maio de 1969, com a fixação do imposto de exportação sobre o café solúvel.

Em julho de 1968 o Acordo Internacional do Ca fé foi ratificado pelo Senado norte-americano, entrando em $v \underline{\mathbf{i}}$ gor a partir de 19 de outubro de 1968.

No ano seguinte à assinatura do Acordo Interna cional do Café de 1968, foi grande a instabilidade no mercado internacional. As baixas verificadas nas cotaçoes do produto foram resultantes da retração da demanda mundial, principal mente dos Estados Unidos, maior importador mundial. Além do excesso de oferta no mercado, em consequência da retração do consumo, adiciona-se as exportações efetuadas fora do sistema 
de cota, em que o café era exportado para novos mercados posteriormente enviado para os compradores tradicionais.

Ao finalizar a década de 60 , o Brasil passou de uma fase de grandes volumes de produção de café para outra de déficit de produção o que iniciou-se na safra 1966/1967. A redução da produção brasileira de café teve como causas as con diçoes climáticas adversas (geadas e secas), envelhecimentode grande parte da lavoura cafeeira, "erradicação voluntäria ou indenizada dos cafezais", "tratos inadequados e rudimentares da lavoura" (CONJUNTURA ECONOMICA, 1970), além da ferrugem e broca do cafeeiro, com grave incidencia no final da década.

No inicio dos anos 70 intensificou a ferrugem nos cafezais, notadamente nos Estados da Bahia, Espirito San to e Minas Gerais, o que provocou grandes reduções na safra brasileira de café e consequente elevação dos preços do café do Brasil no mercado internacional.

A queda da produção brasileira de café cont nuou na década de 70. O Brasil manteve seu volume de exporta ção devido aos volumosos estoques governamentais existentes. o governo brasileiro instituiu os denominados "negócios espe ciais", através dos quais eram dados descontos nos preços de café para os torradores estrangeiros que adquirissem o produ to diretamente do Brasil.

No primeiro semestre de 1972 foi instituido o Plano Trienal de Renovação e Revigoramento da Cafeicultura, que previa a plantação de 600 milhões de cafeeiros até 1975, sendo plantados em média $200 \mathrm{milhões} \mathrm{de} \mathrm{pés} \mathrm{por} \mathrm{ano.} \mathrm{A} \mathrm{adoção}$ do plano pelo Governo federal deu-se pelo não atendimento da produça brasileira de café ao volume exportável e ao consumo doméstico. O Plano visava recuperar a produção brasileira do 
produto ao nível aproximado de 26 a 28 milhões de sacas anuais.

Os entendimentos entre países produtores de café reiniciaram em maio de 1969 e vieram a se consolidar em principio de 1972 (CONJUNTURA ECONOMICA, 1973 (27) pp.83-85). As nações produtoras reuniram-se para adotar medidas que neutralizassem as politicas econômicas implementadas pelogoverno americano na época. Com a intensificação da crise internacional a partir de 1971, e a desvalorização do dólar, os paí ses produtores de café perceberam a urgência de adoção de me didas que garantissem o comércio internacional do produto.

De janeiro a fevereiro de 1972, os principais países produtores de café (Brasil, Colômbia, Costa do Marfim, Angola, Guatemala, El Salvador, México, Costa Rica e Uganda), propuseram à Organização Internacional do Café, aumento dos preços para compensar a desvalorização do dólar. Após longa discussão a proposta não foi aceita pelos países consumidores. os paises produtores voltaram a se reunir em março de 1972 , propondo uma coordenação de medidas comerciais de curto prazo, que influissem no mercado mundial de café.

Os paises consumidores, principalmente os Esta dos Unidos, não concordaram com a iniciativa dos produtores, argumentando que estes estavam violando o Acordo Internacio nal do Café. A falta de consenso entre países produtores e con sumidores fez com que, na 20 ạ sessão co Conselho, não fosse possivel fixar o nivel da cota de exportação para o ano cafe eiro 1972/1973, e renovar o Acordo Internacional do Café.

No inicio de 1973 foi prorrogado o Acordo In ternacional do Café por dois anos, com vigência a partir de 19 de outubro de 1973. O Acordo tinha como objetivo "prover um foro para a discussão dos problemas do café e para as reuniōes 
dos países produtores e consumidores do produto" e "prover um ponto focal para a coleta e a disseminação das estatíst cas do cafë", (CONJUNTURA ECONOMICA, 1973). Este Acordo não possuía mecanismos de regulamentação do mercado mundial de ca fé. Segundo os países consumidores, após o ano de 1973 o Acor do Internacional do Café não era mais necessārio em vista da redução do excedente de produção e a tendência para o equili brio relativo entre oferta e demanda do produto.

No entanto, a conjuntura prevalecente na épo ca levou à maior unidade entre os países produtores, aumentan do progressivamente a participação dos países produtores no Comitè de Coordenação, que fixava medidas comerciais para a regularização do mercado mundial de café.

Na vigência do Acordo Internacional do Café de 1973, o comportamento do mercado mundial do café foi relativa mente favorável aos países exportadores, havendo uma recupera ção das cotações internacionais do produto, especialmente do café brasileiro, devida à redução das safras, prejudicadas por fatores climáticos. Em meados de 1975 ocorreu forte geada no sul do país, ocasionando grande redução na produção brasi leira de café e elevados prejuízos aos cafeicultores.

Na reunião da Organização Internacional do Ca fé, em novembro de 1975, tiveram início as negociações para a renovação do Acordo de Café que entraria em vigência a partir de 19 de outubro de 1976. Um Grupo de contato apresentou ao Conselho da Organização Internacional do Café as seguintes pro postas, as quais foram aprovadas em 26 de novembro de 1975:

"O Acordo seria renovado por seis anos. Antes do final do primeirotriênio, os membros informariam à organi zação se pretendiam continuar membros do pacto por mais três anos"; 
"As cotas anuais e trimestrais seriam atribuidas a cada país produtor, divididas em duas parcelas: a cota fixa, baseada em $70 \%$ da média das exportações do primeiro ano convênio 1976/1977; os restantes $30 \%$ como cota variável, ba seada nos estoques existentes no país produtor ao fim do ano sa fra anterior, de maneira proporcional à relação existente en tre os estoques verificados de cada membro exportador e o to tal dos estoques de todos os membros exportadores";

"Cada país produtor notificaria a Organização Internacional do Café, até o fim do sexto mês do ano cafeeiro, quando não pudesse completar sua cota de exportação parao ano cafeeiro corrente. Nesse caso a cota seria aumentada no ano cafeeiro seguinte de $30 \%$, sendo reduzidas as cotas dos países que tinham se beneficiado com a redistribuição";

"As cotas entrariam em vigência imediatamente à formalização do convênio: sempre que, num período de 20 dias consecutivos de mercado, a mëdia do preço indicativo com posto não ultrapassar o limite mäximo da faixa de preços esta belecida pelo Conselho em vigor; no caso de não ser adotada faixa de preço: num período de 20 dias de mercado a média dos preços indicativos dos cafés robustas e outros suaves não for superior à alcançada no ano civil de 1975, ou se durante 20 dias consecutivos de mercado a mëdia do indicativo composto ëstabelecido pelo Conselho situar-se pelo menos $15 \%$ abaixo da mëdia do ano cafeeiro anterior"; e

"O Conselho estabeleceria um sistema de preços indicativos que permitissem o estabelecimento e a suspensão de cotas e seu ajustamento pró rata e tambēm a aplicação de aumentos seletivos de cotas em função de flutuações do preço indicativo dos diferentes tipos de café"'. (CONJUNTURA ECONOMI CA, 1975).

No ano seguinte em 30 de setembro, o Acordo foi 
ratificado, entrando em vigor em 1 o de outubro de 1976.0 perío do 1975-1977 representou o "boom" dos preços no mercadó exter no devido às geadas ocorridas em 1975 e ao suporte do Acordo Internacional do Café.

Em 1979, as exportação brasileira de café foram satisfatórias devido à estratégia de venda adotada pelo Insti tuto Brasileiro do Café (IBC). Por outro lado, a expectativa de geadas em julho, no sul do Brasil, provocou reação dos preços no mercado externo. Acrescenta-se à boa performance do mercado cafeeiro em 1979, a politica executada por um grupo de países produtores latino-americanos, o chamado grupo de Bo gotá, que vinha interferindo ativamente no mercado, e à retra ção da oferta brasileira devido aos reduzidos estoques internos, que contribuiu para a sustentação das cotações do produ to.

o custo para o Brasil da política de retração da oferta de café no mercado internacional reflete-se na não reconquista dos mercados e perda parcial dos novos mercados. Considerando-se que o potencial de produção brasileira de ca fé na época, estava em torno de $30 \mathrm{milhões} \mathrm{de} \mathrm{sacas/ano,} \mathrm{evi-}$ denciava-se a necessidade de mudanças na politica de comercia lização, para uma maior participação do país no mercado inter nacional. Observa-se pelos dados da Tabela 03 , a queda da par ticipação das exportações brasileira de café em relação ao to tal mundial exportado. A participação no período de 1970-1973 era superior a $30 \%$, passando em 1979 para $19,2 \%$ ao mesmo tem po em que a participação da Colômbia subia para $18 \%$.

Com o objetivo de aumentar a sua participação no mercado internacional, o Brasil decidiu conceder descontos nas vendas de café para o exterior a partir de dezembro de 1979, o que provocou o declínio dos preços. Outros fatores foram 
40

Tabela 03. Participação Percentual dos Principais Países Ex portadores nas Exportações Mundiais de Café Cru em Grãos

$1962-1981$

\begin{tabular}{|c|c|c|c|c|c|c|c|c|}
\hline Pericdo & Brasil & Colónbia & EI & Salvador & Indonēsia & México & Demais Paises & $\begin{array}{l}\text { Total } \\
1.000 \mathrm{t}\end{array}$ \\
\hline $196 ?$ & 35,4 & 14,2 & & $3, ?$ & 2,1 & 3,1 & 42,00 & $2.775,3$ \\
\hline 1963 & 39,9 & 12,5 & & 3,2 & 2,0 & 2,5 & 39,87 & $2.334,3$ \\
\hline 1964 & 31,9 & 13,7 & & 3,8 & 2,2 & 3,8 & 44,52 & 2.803 .2 \\
\hline 1555 & 30,0 & 12,6 & & 3,7 & 4,0 & 3,0 & 46,76 & $2.698,1$ \\
\hline 196.6 & 34,7 & 11,4 & 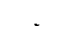 & 3,3 & 3,4 & 3,1 & 44,07 & $2.941,6$ \\
\hline 1957 & 34,5 & 12,1 & & 4,0 & 4,4 & 2,6 & 42,35 & $3.013,1$ \\
\hline 1968 & 35,5 & 12,3 & & 3,7 & 2,5 & 3,0 & 43,09 & $3.216,4$ \\
\hline 1969 & 36,2 & 12,0 & $\because$ & 3,5 & 3,0 & 3,0 & 42,35 & $3.251,7$ \\
\hline 1374 & 32,4 & 12,3 & & 3,5 & 2,7 & 2,7 & 45,31 & $3.163,3$ \\
\hline 1971 & $34,1:$ & 12,3 & & 3,2 & 2,1 & 3,0 & 45,01 & $3.203,3$ \\
\hline$i 9 \% 2$ & 33,2 & 11,3 & & 3,6 & 2,4 & 3,0 & 46,53 & $3.471,9$ \\
\hline 1973 & 31,7 & 10,8 & & 4,0 & 2,6 & 3,7 & 47,23 & 3.755 .0 \\
\hline 1974 & 24,2 & 12,6 & & 4,7 & 3,3 & 3,6 & 51,64 & $3.287,2$ \\
\hline 1975 & 25,2 & 14,1 & & 5,3 & 3,7 & 4,1 & 47,51 & 3.474 .7 \\
\hline 1976 & 26,5 & 10,7 & & 4,5 & 3,6 & 4,7 & 49,99 & $3.528,3$ \\
\hline 1977 & 21,6 & 11,3 & & 6,4 & 5,3 & 3,8 & 51,61 & $2.830,0$ \\
\hline 1973 & 22,4 & 16,1 & & 4,2 & 6,2 & 3,5 & 47.71 & $3.36 \hat{0}, 7$ \\
\hline 1979 & 19,2 & 17,8 & & 5,4 & 5,8 & 4,8 & $1,7,10$ & $3.757,2$ \\
\hline 1380 & 25,5 & 18.7 & & 4,9 & 6,0 & 3,7 & 41,18 & $3.552,7$ \\
\hline 1981 & 26,4 & 15,0 & & 3,6 & 6,1 & 3,3 & 45,61 & $3.632,8$ \\
\hline
\end{tabular}

Fonte: Dados Preliminares-Anuário Estatístico do Café 1976 $M I C-I B C$

Anuàrio Estatístico do Café 1980/8I MIC - IBC 
tambēm responsāveis pela contínua queda das cotações: a redução da liquidez do grupo de Bogotä e a divulgação do volu me das safras brasileiras de $1979 / 1980$ e $1980 / 1981$ (21,6 mi 1hões e 21,2 milhões de sacas, respectivamente).

Apesar da fraqueza do mercado no inicio de 1980 , as exportações brasileira de café, no primeiro semestre, tiveram uma boa performance. O melhor desempenho das vendas ex ternas foi atribuido à sistemātica de comercialização adota da pelo IBC. Esta consistia em "Avisos de Garantia" (títulos a serem descontados nas futuras aquisições) ao importador, ou seja, o "importador receberia a diferença entre o preço ofic al de venda do Brasil e a média das cotações do café de ou tras origens" (AGROANALYSIS, 1980). Assim, o Brasil iniciou a reconquista de mercado, ao mesmo tempo em que dava suporte às cotações internacionais.

A decisão do IBC de utilizar a nova estratégia de venda de algum modo tentava corrigir a retração da oferta brasileira em anos anteriores, em que o país arcou sozinho com - peso de elevados estoques.

Em que pese os bons resultados das exportações brasileira de café no primeiro semestre de 1980 , as cotaços iniciaram o declínio no mês de junho. Em parte, a queda de pre ços no mercado internacional foi atribuída ao aumento da ofer ta brasileira, porém, supunha-se que a tendência baixista dos preços era provocada por manobras especulativas. As suspeitas de manobras especulativas de preços podiam ser evidenciadas pe lo aumento dos estoque de café nos Estados Unidos no primei ro semestre e a redução das compras de café no período seguin te, com o objetivo de reduzir os preços.

Dentro do quadro que se configurava de tendên 
cia baixista dos preços, foi assinado o Acordo Internacional do Café, em outubro de 1980. O Acordo estabelecia que as co tas de exportação dos países membros da Organização Interna cional do Café, fossem reduzidas em $2,4 \%$ em relação à cota global (fixada em 57,37 milhões de sacas), sempre que a média móvel do preço indicativo composto da Organização Internacio nal do Café, fosse menor que US $\$ 1,20 / 1 b$, durante vinte dias. Em novembro e dezembro houve redução da cota, totalizando a cota global em 54,1 milhões de sacas.

As cotações mantiveram-se acima de US $\$ 1,20 \%$ b, durante boa parte do período 1980/1981. Sem dūvida, a eficá cia do Acordo Internacional do Café levou à sustentação dos preços do produto acima de US $\$ 1,20 / 1 b$.

Em meados de 1981, os cafeicultores reivindica vam medidas urgentes por parte do Governo federal, para a cri se cafeeira. o mercado encontrava-se desequilibrado devido ao excesso de produção e à redução dos preços internacionais do produto. A crise cafeeira que se configurava teve origem na grande geada de 1975. Com a queda da produção brasileira de café, o Governo federal procurou apoiar e incentivar a recupe ração do parque nacional cafeeiro e diversificar as áreas de plantio do produto, o que resultou na expansão significativa da produção, sem que houvesse capacidade de absorção pelo mer cado.

No entanto, em julho de 1981 ocorreu geadas prejudicando a produção dos três principais estados produto res de café (São Paulo, Minas Gerais e Paraná), comprometendo aproximadamente $50 \%$ da safra seguinte, o que provocou uma ex pectativa otimista. As cotações no mercado internacional au mentaram no curto prazo, mas em seguida voltaram a tendencia de baixa, já que a redução da safra se daria somente em mea 
dos de 1982. Os preços permaneceram relativamente estáveis, pelas incertezas existentes no mercado sobre as futuras negociações para a renovação do Acordo.

Após intensas negociações o Acordo Internacio nal do Café foi renovado em setembro de 1981. A cota global foi fixada em 56 milhões de sacas para o intervalo de preços de US $\$ 1,20 / 1 \mathrm{~b}$ e US $\$ 1,40 / 1 \mathrm{~b}$. O documento estipulava que se riam feitos no máximo quatro cortes ou acréscimos sobre a co ta global, totalizando um volume de 4 milhões de sacas.

Embora o Acordo viesse sustentar os preços in ternacionais de café no curto prazo, os efeitos foram positivos, principalmente numa situação de excesso de oferta no mer cado mundial do produto. As cotações no segundo semestre de 1981 aumentaram no curto prazo, em consequência da geada de julho, da atuação do Acordo Internacional do Café e do sistema de distribuição de cota interna, instituido pelo IBC. A tendência de alta continuou no primeiro semestre de 1982 , caracterizada também pelo aumento da demanda dos torrefadores nos meses de inverno no hemisfério norte e pelo nivel mais ba xo dos estoques nos países consumidores. Os estoques estavam fortemente reduzidos devido às altas taxas de juros prevalecentes no mercado.

Em julho de 1982 tiveram início as negociações para renovação do pacto. Na Assembleia de setembro, países produtores e consumidores de café chegaram ao consenso, renovando o Acordo por seis anos. As principais cláusulas econômi cas seriam revistas anualmente. A cota bäsica foi fixada em 52,8 milhões de sacas para 1982/1983. Os principais paises produtores, Brasil e Colómbia, foram os mais beneficiados com a distribuição da cota. O Brasil recebeu $30 \%$ e a Colómbia $16 \%$ da cota básica. As normas quanto aos preços de intervenção e 
- volume a ser retirado ou colocado no mercado internacional, permaneceram os mesmos do Acordo de setembro de 1981 .

No período 1981/1982, a maioria das"commodities" iniciaram uma contínua queda de preços mesmo aqueles pro dutos que possuiam Acordos Internacionais. A situação de cri se na economia internacional contribuiu para o declínio das cotações das "commodities". As elevadas taxas de juros e cres cimento económico praticamente negativo, provocaram a redu ção da demanda internacional. Por outro lado, o excesso de oferta no mercado internacional reforçava o declinio dos preços.

Todavia, os preços dó café mantinham-se táveis, o que pode ser atribuido ao desempenho do Acordo In ternacional do Café, que cumpria sua função de estabilizador de preços. Os bons resultados obtidos com as exportaçóes bra sileira de café em 1981/1982, devem-se, em especial, à eficá cia do Acordo Internacional do Café, que proporcionou preços externos mais estäveis. Com seus mecanismos de controle, o Acordo pode reduzir a oferta do produto no mercado internacio nal e assegurar êxito com a fixação de cota de exportação pa ra cada país exportador.

\subsection{Acordos Internacionais de Açūcar}

A produção de açūcar se verifica tanto em cli mas tropicais como em climas temperados e frios. As nações de clima tropical produzem o açūcar de cana enquanto que as na çöes de clima temperado e frio produzem açücar de beterraba.

os principais países produtores de açücar de cana são Brasil, Cuba, Austrālia, Repüblica Dominicana, Fili 
pinas, India, Africa do Sul, Tailândia e Argentina. Os princi pais países produtores de açūcar de beterraba são Inglaterra, Alemanha Ocidental, Bēlgica, Polônia, França, Áustria e Tchecoslovāquia.

A concorrência entre a produção de açūcares de cana e de beterraba vem desde os meados do sēculo XIX. Apös algumas tentativas de minorar o impasse da concorrência, ocor reu à Convenção de Bruxelas em 1902, onde os países partici pantes foram Alemanha Ocidental, Austria, Hungria, Bélgica, Espanha, França, Itälia, Noruega, Países Baixos, Reino Unido e Suécia. Os efeitos da Convenção de Bruxelas foram neutral zados pelo início da I Guerra Mundial em 1914.

Com a guerra, a produção dos países europeus diminuiu, sendo os estoques consumidos rapidamente. Cuba e outros países produtores de açücar de cana investiram para aumentar suas produções. Os preços do açūcar aumentaram e, mes mo com o fim da guerra, os preços continuaram em nível ascen dente devido à excassez do produto.

Os europeus iniciaram a recuperação de suas plantações e anos depois, em 1925/1926, a economia açucareira se deparava com uma crise de super produção e baixa de preços.

A partir da crise intensificaram-se os esfor ços para a formalização de um Acordo Internacional do Açūcar. Um representante cubano, José Miguel Tarafa, argumentava so bre a necessidade de entendimentos internacionais que adotas sem medidas para a estabilização do mercado açucareiro. os en tendimentos de Tarafa para a redução da produção de açūcar , com os representantes da Tchecosloväquia, Polónia e Alemanha ocidental, levou o Comitê Consultivo Econômico da Sociedade das Nações a preocupar-se com os excessos de produção e ba 
xos preços do açūcar.

Na reunião de Bruxelas, em 1928, compareceram representantes da Alemanha Ocidentall, Bëlgica, Cuba, Hungria, Polônia e Tchecosloväquia. Os representantes concluíram que seria necessário a redução da produção de açūcar por um perío do de quatro anos. A esta proposta não houve adesão de ou tros grandes paises produtores como Repüblica Dominicana, Pé ru, Filipinas e Java.

Cuba, em 1927, tinha adotado uma politica de limite às suas safras. Com o insucesso do Plano Tarafa tal po litica foi suspensa, mas a situação desfavorável no mercado açucareiro levou o país a adotar um "Sistema de Unificaçãode Vendas" (MONT'ALEGRE, 1976, p.180) no qual era favorecido o açücar comercializado com os Estados Unidos. Cuba ainda ten tou obter vantagens com outros países não logrando êxito.

Em 1930 intensificou a crise na economia açuca reira, com grandes volumes de produção e declínio nos preços. Para maior agravamento da situação, os Estados Unidos, cance lou o Tratado de Reciprocidade Comercial, fixando altas tari fas protecionistas para o açūcar de produção interna. Por ou tro lado, o Reino Unido incentivou e intensificou a expansão da produção de açūcar nas ilhas de Trinidad e Maurício, na Ja maica e na Austrälia, alēm da Guiana.

A partir desta crise tornava-se cada vez mais urgente procurar uma maneira de estabilizar o mercado mundial de açúcar. Dado que a maior parte dos capitais investidos na cultura de açúcar em Cuba, eram americanos, foi designado o advogado de Nova lorque, Thomas L. Chadbourne, para encontrar a melhor solução. A partir do Comitê cubano-americano, inten sas negociações tiveram inicio em novembro de 1930 , em Bruxe 
las e Amsterdã e posteriormente em Paris e Berlim. Finalmente, em maio de 1931, foi assinado o Convênio Thomas L. Chad bourne, em Bruxelas, para um período de cinco anos. Aderiram ao Convênio Cuba, Alemanha Ocidental, Polônia, Tchecoslováquia, Bëlgica, Hungria e Java.

Os principais objetivos deste Acordo eram regu lar a produção mundial de açücar, de modo a equilibrá-la com o consumo. Pelo lado dos produtores e exportadores, esperava- se a redução da produção e da exportação. O fracasso do Acor do de Chadbourne deveu-se a não adesão da grande maioria dos paises produtores, pois, enquanto os signatários limitavam su as produções e exportações, os não signatärios continuavam a aumentar suas produções, contribuindo para o agravamento do declínio dos preços. Diante deste quadro, o Acordo de Chad bourne foi extinto em setembro de 1935, um ano antes do tem po previsto para seu tērmino.

Para os países exportadores, a situação que se apresentava era critica, pois a produção de açūcar nos países importadores era incentivada, levando ao maior declínio das exportações dos fornecedores tradicionais.

A crise no mercado internacional de açücar levou os países exportadores a reivindicarem um entendimento multilateral, visando a estabilização do mercado açucareiro. A Secretaria da Conferência Monetäria e Econômica Mundial pro moveu em Londres, em abril de 1937, a Conferência Açucareira Internacional, para discutir a implementação do Acordo Inter nacional do Açúcar, que passaria a vigorar em 1 o de setembro de 1937, por um período de cinco anos. O Acordo Internacional do Açücar de 1937 tinha como objetivos equilibrar a oferta e demanda de açücar, promover e expandir o consumo, garantir pre ços remuneradores aos produtores e preços razoáveisaos consumidores. 
Nos anos que se seguiram ao Acordo a produção de açücar continuou crescendo. No final de 1939, no início da Il Guerra Mundial, a economia açucareira apresentava-se com excesso de produção. A produção mundial de açücar na safra... $1940 / 1941$ foi de 29,7 milhões de toneladas. Neste contexto, em 1942 expirou o prazo de vigência do Acordo Internacional do Açūcar de 1937. O Conselho Internacional do Açūcar renovou o Acordo até agosto de $19445 /$, não obtendo as assinaturas da Alemanha 0cidental, China, França, Hungria, Tndia, Iugoslávia e Polônia.

Durante a 11 Guerra Mundial a produção total de açücar diminuiu, notadamente nos países produtores do açücar de beterraba, muitos deles envolvidos no conflito.

Logo apōs o tērmino da Guerra, os países in ciaram a rápida recuperação da cultura do açūcar, enquanto ou tros países, como Cuba, Brasil e Porto Rico, continuavam a au mentar suas produções. 0 aumento da produção mundial de açú car, não acompanhado pelo aumento do consumo, levou novamente a excedentes de produção. Ficava evidenciado.a necessidade de um novo entendimento a nivel internacional.

Em agosto de 1948 reuniu-se o Conselho Inter nacional do Açūcar por solicitação de Cuba, que argumentava que o Acordo Internacional do Açūcar de 1937 não mais atendia aos interesses dos países produtores, uma vez que os países importadores não cumpriam a quantidade mínima para consumo a cota de exportação. Somente o Brasil aderiu às solicitações de Cuba, pois os demais países não se interessaram, já que não possuíam excedente de produção.

Na reunião do Comitê Especial de junho de 1950,

5/O Acordo de 1937 foi sendo renovado atë 1952 . 
Cuba voltou com um projeto onde as principais propostas eram:

- "Facilitar e aumentar o consumo de açúcar no

mundo;

- Limitação da produção de açūcar nos países importadores;

- Regular o fornecimento de açúcar no mercado internacional;

- Estabilização dos preços numa faixa de máxí mo e minimo; e

- Estipular sobre a discriminação dos países não participantes do Acordo" (MONT'ALEGRE, 1976 p. 189).

Na época, os principais exportadores e impor tadores tinham interesses adversos. Os países importadores, co mo os Estados Unidos, não queriam abrir mão das importações preferenciais de Cuba.. O Reino Unido visava aumentar a produ ção interna para reduzir suas importações, com o objetivo de reequilibrar sua balança comercial apōs a guerra. A França con siderava-se auto-suficiente com sua produção interna. Da mes ma maneira, os países Baixos visavam a auto-suficiência. Por outro lado, os países exportadores como Cuba, República Dominicana e peru, possuíam excedentes de produção e solicitavam aumento de suas cotas de exportação.

o Conflito da Corëia levou ao receio de uma nova guerra mundial, havendo aumento da demanda dos produtos primários e provocando a elevação dos preços. Mas, no final de 1952, os grandes exportadores estavam com volumosos estoques, o que provocou a reação de Cuba de reter no campo dois milhōes de toneladas de açūcar da safra de 1953. Nesta época, - Reino Unido reiniciou as importações de açūcar, inclusive para reposição dos seus estoques, firmando contratos com Cuba. 
A Alemanha ocidental tambëm fez grandes compras de açücar cu bano.

As expectativas de maiores estoques no mercado mundial de açücar em 1953, levou à negociações multilaterais para a implantação de um novo Acordo. Em julho de 1953, em Londres, reuniu-se a Conferência Internacional do Açúcar. Nes ta reunião ficou clara a divergência de interesses entre os 52 paises participantes. Alguns paises desejavam passar de im portadores para exportadores e os exportadores tradicionais tentavam ampliar suas exportações em detrimento daqueles pa ses que não possuíam cota.

0 problema maior para os países produtores de açūcar de cana era a definição das cotas básicas de exportä ção. 0 Brasil solicitava uma cota de $400 \mathrm{mil}$ toneladas, pois, no Acordo anterior sua cota foi de $60 \mathrm{mil}$ toneladas. No Acor do Internacional do Açūcar de 1953 foi fixada uma faixa de preço: o preço máximo foi de USદ્ 4,25/lb e o preço mínimo de US $\not \subset 3,25 / 1 b$. As cotas variavam conforme o nivel de preços. 0 Acordo foi assinado em agosto de 1953 por 16 países importado res e 22 países exportadores e entraria em vigor em janeiro de 1954, por um período de cinco anos, sendo revisado no ter ceiro ano de vigência.

o que se verificou foi a distribuição arbitrá ria das cotas de exportação, provocando descontentamento en tre diversos países, entre eles o Brasil, que não concordou com a distribuição das cotas. O Brasil, Peru, Indonésia e In dia retiraram-se do Acordo. Assim, o Acordo Internacional do Açúcar de 1953 perdia boa parte de seu êxito, jä que esses paí ses iriam se comportar à revelia no mercado internacional do açücar. 
0 Acordo de 1953 proporcionou uma certa estabilidade de curto prazo no mercado açucareiro, chegando a uma firmeza nos anos de 1957 a 1958. Neste periodo, o Brasil expan diu suas exportações aproveitando-se da excassez de safra.. de alguns países. Os preços no mercado de Nova lorque elevaram

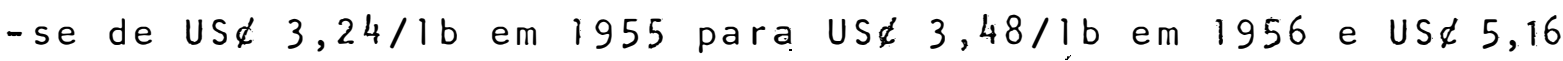
/lb em 1957, declinando para US\& 3,50/lb em 1958 devido à gran de safra deste ano, dando início a novos excedentes de produ ção que continuaram até 1961. O aumento de preços nos dois ültimos anos de vigência do Acordo de 1953 também foi atri buido ao aumento das compras de açücar por parte do Reino Un $\mathbf{i}$ do, no mercado livre mundial, e pelo aumento das importações da União Soviētica, que teve sua safra reduzida.

A reunião preparatōria para implementação de um novo Acordo Internacional do Açücar foi em Havana, em maio de 1958. A reunião teve como objetivos avaliar a economia açu careira e tentar a adesão do Brasil e Peru no novo Acordo. 0 Brasil estaria disposto a participar do novo Acordo, desde que fosse favorável a sua participação no mercado internacional.

Os representantes dos países exportadores e importadores de açūcar reuniram-se em Genebra para implanta ção do novo Acordo. O Acordo Internacional do Açūcar de 1958 não se diferenciava do anterior. Foram feitas apenas algumas modificações. A questão de maior divergência era novamente a distribuição das cotas de exportação. Após longo debate, dec diu-se que, para os países participantes do Acordo anterior, as cotas não seriam alteradas. Países como Brasil e Peru receberiam cotas conforme as previsões de aumento de demanda.

0 Acordo entrou em vigor em janeiro de 1959, sendo que em seguida, Fidel Castro venceu a revolução em Cu ba. Os preços do açúcar no mercado internacional declinaram 
para US $\notin 2,97 / 1 b$ e no ano seguinte houve uma melhora, quando os preços alcançaram em mëdia US\& 3,14/1b, voltando a cair para US $\not 2,80 / 1 \mathrm{~b}$ em 1961. No segundo semestre de 1961, confor me previsto, houve a reunião em Genebra para avaliação do Acor do. Nesta época, os Estados Unidos haviam rompido suas rela ções diplomáticas com cuba e, consequentemente, cancelado suas importações de açūcar cubano. Caberia à União Soviētica e a outros países do bloco socialista passar a absorver o açücar de Cuba.

Os desentendimentos entre Estados Unidos e Cu ba, causou problemas para Cuba, que deixou de receber preços remunerativos pela metade de suas exportações de açúcar. Por outro lado, os Estados Unidos tinham Cuba praticamente como seu ünico mercado fornecedor. A partir daí os Estados Unidos passaram a incrementar a produção interna de açūcar, diminuin do sua dependência externa.

A União Soviētica passou a incentivar o incre mento do consumo per capita de açūcar, já que estava absorven do boa parte do produto cubano. A cota de exportação atribuí da a Cuba no Acordo de 1958 seria insuficiente para suas ex portações no momento. A reivindicação de Cuba, de aumentar sua cota de exportação apoiada pelos países do bloco socialista, tornou impossível chegar a um consenso para a continuação do Acordo. Por esta razão o mercado açucareiro mundial, funcio nou livremente de janeiro de 1962 a dezembro de 1968.

Em 1962 houve a queda na produção mundial de açücar e aumento do consumo, levando à excassez do produto e à elevação dos preços que atingiram US $\not<, 48 / 1 b$. A excassez no período de 1962 a 1963 levou os países a ampliarem a capacidade instalada, baseados em estudos que mostravam a necess dade de amplia-la para acompanhar o aumento de demanda, devi- 
do ao aumento da população e da renda. os altos preços que vigoravam na época e a livre comercialização do açücar, incen tivaram o aumento da capacidade instalada, o que levou ao au mento da produção e o retorno dos excedentes de produção.

Em 1964 iniciou o declínio de preços, atingin do niveis próximos aos da crise de 1929/1930. Assim, os pai ses exportadores e importadores de açūcar voltaram às negocia ções para um novo Acordo, mas somente no segundo semestre de 1968 foi firmado o novo Acordo Internacional do Açücar, que entraria em vigor em janeiro de 1969. 0 Acordo teria duração de cinco anos e seria revisado no final do terceiro ano de vi gência. Conforme o esperado, os Estados Unidos e a Comunidade Econômica Européia não aderiram ao Acordo.

No novo Acordo houve ampliação dos mercados sob arranjos preferenciais (como o existente anteriormente entre Cuba e Estados Unidos); particularmente entre Cuba e União So viética e outros países do bloco socialista. Foi estabelecida maior vinculação entre o esquema de cotas e preços. 0 preço mínimo estipulado no Acordo foi de US $\not \subset 3,25 / 1 b$, apōs longa negociação entre países exportadores e importadores, prevalecendo ao final, a posição dos países importadores.

Para amenizar a decisão da CEE de não aderir ao Acordo, o Artigo 28 estipulava restrições às importações por países-membros de países não membros do pacto, para que fosse atingido o objetivo de recuperação e estabilização de preços.

A partir do final de 1971 começaram as expecta tivas de excassez do produto levando ao aumento dos preços, e provocando, inclusive, a liberação pelo conselho Internacio nal do Açúcar das cotas de exportação, em janeiro de 1972. A 
decisão favoreceu ao Brasil que pode se desfazer dos seus excedentes de produção. Os preços do açücar no mercado inter nacional, durante a vigência do Acordo de 1968 , começaram a se recuperar a partir de 1969, passando de US $\not 63,20 / 1 \mathrm{~b}$ para US\& $9,6 / 1$ b em 1973 .

Em 1972, os paises exportadores e importadores de açücar iniciaram as conversações para a implementação do pröximo Acordo, mas uma série de àcontecimentos colocavam em düvida o. sucesso das negociações:

- "A entrada do Reino Unido na CEE;

- Expiração da politica agrícola da CEE, inclu sive a do açūcar;

- Perspectivas de modificações na politica açu careira norte americana; e

- Predominância no mercado de altos preços re sultante da excassez de oferta de açücar" (MONT'ALEGRE, 1976 p. 222).

Dados os fatores acima, negociar um Acordo pa ra estabilizar os preços, quando estes se encontram em alta, tornava, sem dūvida, dificil os entendimentos. os principais argumentos dos países importadores, liderados pelo Canadá e Japão, eram no sentido de convocar os países exportadores a aumentarem suas produções de açūcar. Pelo lado dos países ex portadores, liderados pelo Brasil, Africa do Sul, Austrälia e Cuba, a questão voltava-se para a divisão das cotas de exportação. Entretanto, a não adesão dos Estados Unidos e da CEE tornou inviável a implantação de um novo Acordo.

Assim, de 1973 a 1977 o mercado açucareiro fun cionou livremente. Em 1974 houve uma significativa elevação dos preços do açücar no mercado internacional. Diversos fato 
res contribuiram para redução da produção e consequente eleva ção dos preços. Entre eles o desestimulo dos produtores, aos baixos preços vigentes no período 1965-1968. A queda dos investimentos agroindustriais dos paises industrializados, nos paises em fase de desenvolvimento, as restrições as exporta ções dos países membros determinadas no Acordo de 1968 e a queda das safras da União Soviética, Cuba e outros países do bloco socialista devido a fatores climáticos.

O consumo mundial per capita cresceu de 1965 a 1974, levando inclusive, à redução dos estoques e a corr da especulativa nas Bolsas de Nova lorque e Londres, fazen do com que o preço do açūcar alcançasse em novembro de $197 \overline{4}$ US $\not 61 / 1 b$.

Com a entrada do Reino Unido no Mercado Comum Europeu, teve que ser revisto o Acordo do Açūcar da Comunida de Britânica. Esse Acordo determinava compromissos mútuos de compra e venda entre países exportadores e importadores de açūcar da Comunidade Britânica. Após sucessivas conversações, foi firmada, em 1975, a Convenção de Lomé. Os países em desen volvimento pertencentes ao Acordo Internacional do Açūcar an terior, formaram, com outros países, o grupo de Estados da Africa, Caribe e Pacífico (ACP). A CEE firmou convênio com os países pertencentes a grupo ACP, para compra anual de uma co ta fixa de 1.305 milhão de toneladas de açūcar, por um preço negociado anualmente. (AGROANALYSIS, janeiro de 1983 p.5).

No entanto, a expectativa quanto a garantia da da pela CEE aos países da ACP, provocou o declínio dos pre ços do açúcar. Mas a principal causa desse declínio foi o crescimento da produção de açúcar, acompanhada de menores ta xas de crescimento do consumo. Os fatores que contribuiram pa ra o aumento da produção foram: 
- Expansão da área plantada devido a incent vos governamentais em alguns paises produtores, influenciados pelos preços de 1974; e

- Ampliação dos parques industriais.

A redução no consumo foi devido não sö aos al tos preços existentes na ëpoca como também ao uso do produto substituto "High Fructose Corn Syrup" (HFCS), desenvolvido nos Estados Unidos. O consumo americano de HFCS passou de 450 mil toneladas em 1975, para l milhão de toneladas em 1977.

Diante da situação de baixa de preços e eleva dos estoques no mercado açucareiro, paises exportadores e im portadores negociaram um novo Acordo em 1977, que entrou em vigência em julho de 1978. A faixa de preço estabelecida foi de US $\not 11 / 1 \mathrm{~b}$ e US $\not 21 / 1 \mathrm{~b}$. Em maio de 1981, a faixa de preço foi fixada em US $\not 13 / 1 \mathrm{~b}$ e US $\not 23 / 1 \mathrm{~b}$. As cotas de exportação variavam de acordo com o comportamento dos preços. Neste Acor do foi estabelecido o mecanismo do estoque regulador, que se ria financiado pelos paises exportadores e importadores per tencentes ao Acordo. Desde o inicio, o Acordo de 1977 foi desacreditado, devido a não adesão dos Estados Unidos e da CEE. Após dois anos de vigência, em 1979, os Estados Unidos aderiram ao pacto. Porém, a elevada participação da CEE nas expor tações mundiais de açúcar, poria em dúvida a efetividade do Acordo.

Dexe-se destacar que o comportamento do consu mo muito contribuiu para instabilidade do mercado açucareiro. A existência de campanhas alegando efeitos maléficos do açü car à saūde e o aumento do uso de sucedâneos, levou à queda no consumo.

A politica da CEE de subsídios e incentivos à 
produção de açūcar, o Programa de Açūcar norte-americano e japonês de expansão da produção de sucedâneos HFCS e os acordos preferenciais de Cuba com os paises do bloco socialista, contribuiram para não efetividade do Acordo Internacional do Açúcar de 1977, particularmente pela não adesão ao pacto da CEE.

Desde 1983 verifica-se negociações multilate rais para a implementação de um novo Acordo Internacional de Açúcar. A CEE tem como principais exigências para aderir ao pacto:

- Intensificação do controle quanto ao desen volvimento de sucedâneos de açūcar;

- Fiscalização aos acordos preferenciais; e

- Maior controle das exportações dos paises desenvolvidos.

Dado que as exigências da CEE vão contra a po lítica de potências como Estados Unidos e Japão, até o momen to os paises exportadores e importadores não chegaram a um consenso para a formalização de um novo Acordo Internacional do Açücar. 


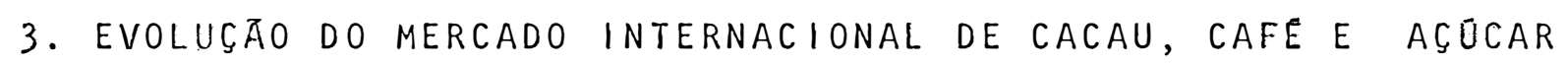
1962-1982

Desde a década de 40 , particularmente no perío do da 11 Guerra Mundial, alguns países entre eles, o Brasil, passaram a adotar uma politica de desenvolvimento. No Brasil a politica teve como base a passagem de um modelo primärioexportador para o modelo de substituíção de importações. Com a implantação deste modelo até mais ou menos 1964, a politica comercial e cambial brasileira de certo modo não favoreceu as exportações (exceto no caso do café). A estratēgia inicialmen te adotada tinha como objetivo principal, o desenvolvimentodo mercado interno.

A crise politica e econōmica interna de 1964 , levou o governo a adotar como prioridade a promoção das expor tações visando o equilíbrio no balanço de pagamentos. o gover no instituiu värias medidas de politica cambial, comercial e fiscal para o incremento das exportações, zockuM (1976).

A partir de 1972, com a criação da Comissão pạ ra Concessão de Benefícios Fiscais a Programas Especiais de Exportação-BEFIEX, foram criados programas especiais para a exportação de produtos manufaturados. 0 novo plano de desen volvimento seria de crescimento econōmico com maior abertura 
para o exterior e diversificação na pauta das exportações.

Neste capitulo, pretende-se analisara evolução do comércio internacional de cacau, café e açücar e o grau de concentração das exportações brasileira de cacau em amêndoas, café cru em grãos e açücar demerara no período 1962-1982. Pro cura-se relacionar os resultados, com as politicas adotadaspe lo Governo brasileiro, de incremento das exportações a partir de meados da década de 60 , com a politica de industrialização brasileira implementada no início dos anos 70 e com a atuação dos Acordos Internacionais de Cacau, Café e Açücar no período de anälise.

3. 1. Mercado Internacional de Cacau.

0 cacau se destaca como importante produto agri cola no mercado internacional. 0 s dados da tabela 04 eviden ciam as mudanças ocorridas na produção de cacau de alguns paí ses. Gana e Nigēria vem diminuindo a produção sendo que o de crēscimo na produção deve-se principalmente a problemas polí ticos em Gana e ao interesse econômico da Nigēria na produção de petröleo. No Brasil, Costa do Marfim, Equador e Malásia a produção tem aumentado significativamente devido a Programas de expansão da lavoura cacaueira.

Observa-se pelos resultados da tabela 05 , que a taxa de crescimento da produção brasileira de cacau em amên doas para o periodo 1962/1963-1981/1982 foi de 5,74\%. Esta taxa de crescimento da produção de cacau em amêndoas deve-se aos altos preços do cacau a partir de 1969, dado a frustração da safra temporão 1968/1969, a tribuída a condições climáticas adversas. Os altos precos incentivaram novos plantios, que, juntamente com condições climáticas favoráveis, levaram ao 
Tabela 04. Produção Mundial de Cacau em Améndoas e Produ. ção dos Principais Países produtores $1962 / 63-1981 / 82$

\begin{tabular}{|c|c|c|c|c|c|c|c|c|c|c|c|}
\hline Perfoco & $\begin{array}{c}\operatorname{cosen} 00 \\
\text { matrin }\end{array}$ & Cons. & Niqerle & topidios & Brastl & lquador & $\begin{array}{l}\text { Repistlico } \\
\text { mominican. }\end{array}$ & molisia & $\begin{array}{l}\text { sub } \\
\text { 101al }\end{array}$ & $\begin{array}{l}\text { Derais } \\
\text { Paises }\end{array}$ & $\begin{array}{l}\text { Botal } \\
\text { Mundial }\end{array}$ \\
\hline $19\{2 / 6\}$ & 101 & 422 & 176 & 25 & 111 & 38 & 37 & $!$ & 961 & 197 & 1.158 \\
\hline $1063 / 56$ & 37 & 136 & 216 & 84 & 123 & 35 & 6 & 1 & 1.033 & 183 & 1.216 \\
\hline $15 \mathrm{Cl}_{4} / 6 \mathrm{~S}$ & 145 & 557 & 296 & 90 & 116 & 47 & 32 & 1 & 1.282 & 200 & 1.482 \\
\hline $1963 / 66$ & 111 & 610 & 182 & 78 & 170 & 35 & 28 & 1 & 1.015 & 190 & 1.205 \\
\hline $1966 / 67$ & 147 & 376 & 263 & BS. & 172 & 52 & 28 & 1 & 1.124 & 209 & 1.333 \\
\hline $1967 / 68$ & 146 & 415 & 235 & 90 & 161 & 68 & 30 & 2 & 1.125 & $20 B$ & 1.333 \\
\hline $191.8 / 69$ & 162 & 334 & 189 & 103 & 163 & 52 & 21 & 2 & 1.006 & 214 & 1.220 \\
\hline $1963 / 70$ & 178 & 409 & 219 & 108 & 197 & 56 & 62 & 3 & 1.210 & 208 & 1.418 \\
\hline $1970 / 71$ & 180 & 392 & 308 & 112 & 182 & 61 & 25 & 4 & 1.264 & 235 & 1.499 \\
\hline $1971 / 72$ & 226 & 664 & 255 & 123 & 167 & 87 & 61 & 5 & 1.368 & 235 & 1.583 \\
\hline 1972173 & 181 & 418 & 241 & 103 & 162 & 43 & 29 & 9 & 1.169 & 208 & 1.397 \\
\hline $1373 / 74$ & 210 & 343 & 215 & 110 & 242 & $\pi$ & 41 & 10 & 1.242 & 205 & 1.447 \\
\hline $1574 / 75$ & 241 & 382 & 214 & 118 & 265 & 25 & 33 & 12 & 1.340 & 210 & 1.550 \\
\hline 1995676 & 227 & 395 & 215 & 96 & 251 & 60 & 32 & 16 & 1.293 & 209 & 1.502 \\
\hline $1976 / 77$ & 230 & 321 & 165 & 82 & 226 & 72 & 38 & 18 & 1.152 & 192 & 1.344 \\
\hline 1972178 & 333 & 270 & 202 & 108 & 279 & 24 & 35 & 22 & 1.303 & 215 & 1.518 \\
\hline $1578 / 79$ & 312 & 255 & 130 & 108 & 309 & 92 & 40 & 27 & 1.293 & 217 & 1.310 \\
\hline $1579 / 33$ & 379 & 275 & 160 & 122 & 296 & 95 & 29 & 34 & 1.393 & $: 23$ & $1.8: 6$ \\
\hline $199: / 81$ & bis & 252 & iss & 118 & 353 & \&) & 35 & 4 & Mhíz & 223 & 1.665 \\
\hline $1591 / 82$ & 456 & 225 & 182 & 122 & $3: 1$ & 85 & 60 & 62 & 1.483 & 236 & 1.719 \\
\hline
\end{tabular}

Fonte: Gill E Duffus Cocoa Market Report n? 249, February 1973 (Dados 1962/63-1969/70).

Gill E Duffus Cocoa Statistics, May 1982 ( Dados $1970 / 71-1972 / 73)$.

Quarterly Bulletin of Cocoa Statistics, Volume IX, number 4, September 1983 - ICCO - London (Dados $1973 / 74-1981 / 82)$. 
Tabela 05. Taxa Geométrica Anual Média de Crescimento nos Pe riodos 1962/63 - 1981/82, 1963 - 1982 - Brasil

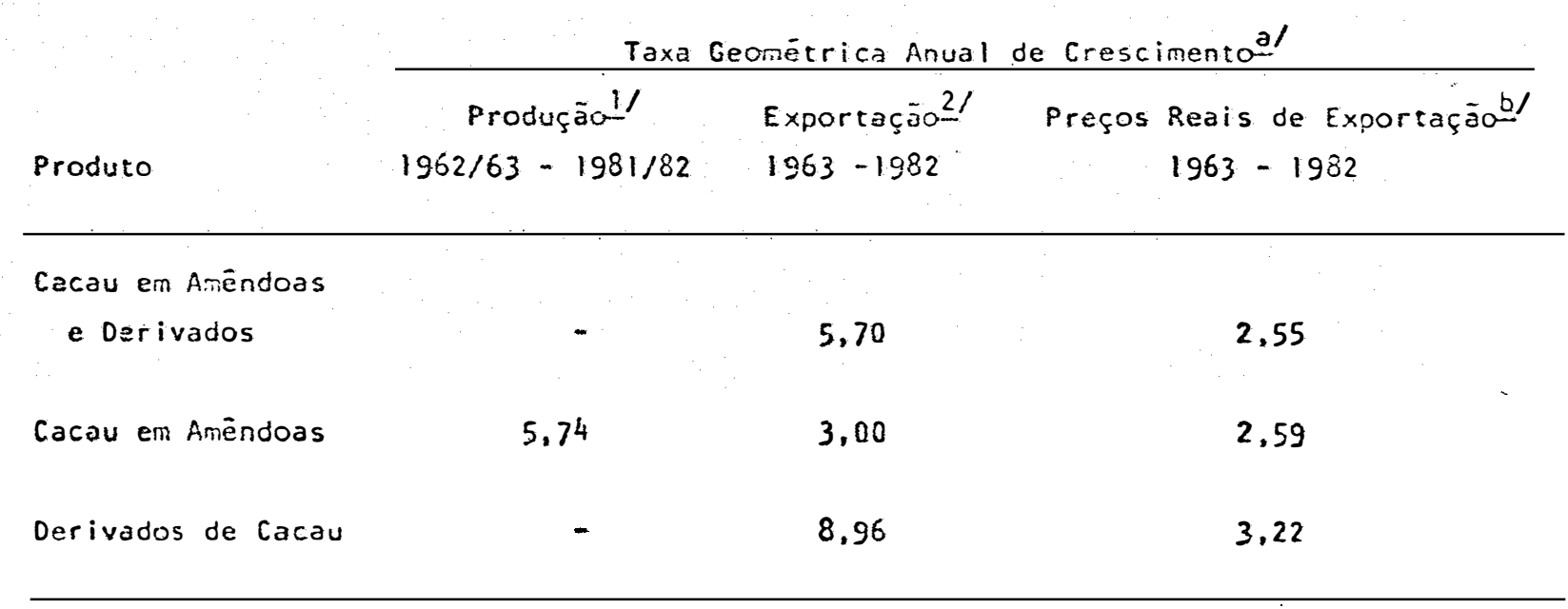

a/ Estimada atravēs do ajustamento da regressäo linear simples onde a variāvel independente é a tendência e a variàvel de pendente é o logaritimo dos valores observados das variá veis. Determinado o coeficiente de regressão (b) a taxa geo métrica anual mēdia ( $r$ ) foi estimadá através da förmula $r=$ antilog $b-1$.

b/ Os preços fob das exportações brasileira de cacau em amên doas e derivados obteve-se dividindo o valor anual médio em dölar das exportações brasileira de cacau em amêndoas e de rivados pelo volume em toneladas das exportações brasileira destes produtos.

os preços em dólar por tonelada foram deflacionados pelo indice de preço no atacado dos Estados Unidos corrigidos, base. $1982=100$.

Fonte:

I/ Gill E Duffus Cocoa Market Report n? 249, February 1973, May 1982 .

Quarterly Bulletin of Cocoa Statistics, Volume $1 x$, number 4 , September 1983 - ICCO - London.

$2 /$ Dados Preliminares - Comércio Exterior Brasil - Banco do Brasil - CACEX - 1963-1982.

Brasil Exportação - Banco do Brasil - CACEX - 1975 - 1982. 
aumento da produção a partir de 1973/1974. Por outro lado, a implantação do Programa de Expansão da Cacauicultura-PRoCACAU, em 1976, contribuiu para o aumento significativo da produção via implantaçãode novas àreas, renovação de cacauais decadentes e modernização da lavoura.

Dentre os principais paises exportadores de ca cau em amêndoas, Gana e Nigēria lideraram as exportaçōes até 1977. Estes países, como grandes produtores de cacau, tinham participação significativa nas exportações mundiais do produ to. Nos ültimos anos, o decréscimo da produção de cacau nes ses países, e a consequente queda na participação nas exporta ções mundiais do produto deve-se à instabilidade política de Gana e ao interesse econômico da Nigēria na exploração do pe tróleo. A participação de Gana e Nigēria na exportação mundial de cacau em amêndoas, em 1962, era de 41,27\% e 19,12\%, respectivamente. Em 1981 a participação de Gana caiu para $16,17 \%$ e da Nigéria para 6,47\%. No entanto, Costa do Marfim e Brasil vêm assumindo a liderança. A participação da Costa do Marfim e Brasil, que em 1962 era de $9,7 \%$ e 5,29\%, respectivamente, passou em 1981, para $37,28 \%$ e $10,64 \%$, respectivamente, (Tabela 06).

A taxa média anual de crescimento das exporta ções brasileira de cacau em amēndoas e derivados no período de 1963-1982, foi de 5,70\%, sendo que para o cacau em amên doas, foi de $3 \%$ e para derivados de cacau 8,96\%. Embora, a ta $x a$ de crescimento das exportaçōes de cacau em amêndoas seja significativa, as exportações de derivados de cacau tiveram crescimento recorde (Tabela 05), devido às profundas modifica ções ocorridas na década de 70, com a intensificação de insta lações de fäbricas de derivados de cacau no Brasil. 0 aumen to da capacidade instalada e a entrada de novas firmas produtoras de derivados de cacau, decorreram dos incentivosfiscais 
Tabela 06. Participação Percentual dos Principais Países Ex portadores nas Exportações Mundiais de Cacau em Amêndoas.

$$
1962-1981
$$

\begin{tabular}{|c|c|c|c|c|c|c|c|c|}
\hline Periodo & $\begin{array}{l}\text { Costa do } \\
\text { Marfim }\end{array}$ & Gana & Nigeria & Camaröes & Brasii & Equacior & $\begin{array}{l}\text { Domais } \\
\text { Paises }\end{array}$ & $\begin{array}{l}\text { Total } \\
1.000 t\end{array}$ \\
\hline 1952 & $9, i 1$ & 41,27 & 19,12 & 5,37 & 5,29 & $3,0.4$ & 15,20 & 1.020 \\
\hline 1963 & 9,57 & 39,55 & $: 7,09$ & 7,62 & 6,64 & 3,42 & 16,11 & 1.024 \\
\hline 1954 & 12,00 & 37,56 & 19.37 & 5,70 & 7,28 & 2,56 & 15,54 & 1.017 \\
\hline 1955 & 9,65 & 38,44 & 23,74 & 5,99 & 7,08 & 3.04 & 12,06 & 1.285 \\
\hline 1905 & 11,15 & 35,83 & 17,37 & 7,04 & 10,24 & 2,93 & $15,4.5$ & 1.204 \\
\hline $196 ?$ & 9,75 & 30,55 & 22,89 & 6,38 & 10,69 & 4,13 & $i 5,20$ & 1.066 \\
\hline 1965 & 11.55 & 31,76 & 19,33 & 6,26 & $=7.22$ & 5,16 & 17,23 & 1.039 \\
\hline 1069 & 11,91 & 24,64 & $17.4 i$ & 7,43 & 12,12 & 3,26 & 23,22 & $\$ \$ 2$ \\
\hline 1970 & 12,77 & 32,77 & $i 7,50$ & 6,43 & 10,63 & 3,21 & $i c, 70$ & 1.120 \\
\hline 197 & 12,30 & 25,23 & 22,76 & 6,61 & 0,36 & 4,27 & $i 7.22$ & 1.025 \\
\hline 1972 & 12,82 & 33,23 & 18,39 & 6.61 & 8.23 & 3.63 & 17.10 & $1.2 \div 0$ \\
\hline 1273 & 13,24 & 34,63 & 19,81 & 7.78 & 7,59 & 2.78 & 14,17 & 1.000 \\
\hline 1074 & 17,90 & 27,42 & 17,21 & 7,77 & 11,27 & 4,08 & 13,45 & 1.145 \\
\hline 1575 & 14,41 & 27,29 & 16,53 & 6,10 & 14,92 & 3.22 & $i 2,54$ & 1.150 \\
\hline 1975 & 17,26 & 29.03 & 19,73 & 6,11 & 11,33 & 1,55 & $i 4.60$ & 1.130 \\
\hline 1977 & 16,63 & 26,63 & 17,68 & 5,58 & 11,26 & 1,89 & 20,32 & 950 \\
\hline 1978 & 23,13 & 20,9 & 17,63 & 5,88 & 12,70 & 1,52 & 18,25 & $i .055$ \\
\hline 1379 & 18,39 & 21,284 & 12,15 & 6,56 & 15,77 & 1,40 & $2 \hat{2} .85$ & 230 \\
\hline 1990 & $27,5 i$ & $20,: 9$ & $13,0 i$ & $7, i i$ & $1 i, 54$ & 1.35 & 17.06 & 1.030 \\
\hline 1031 & 37,28 & 16.17 & 6.47 & 7,05 & 10,64 & 2.30 & 20,09 & 1.775 \\
\hline
\end{tabular}

Fonte: Dados Preliminares - Gill E Duffus Cocoa Market Report, ก? 249, February 1973.

Gill E Duffus Cocoa Market Report, n? 309, October 1983. 
e financeiros concedidos pelo governo federal, com o objetivo de ampliar o parque industrial brasileiro e consequentemente as exportações de produtos industrializados. 6 !

Entre alguns incentivos destacam-se:

- "Financiamento para giroa custos subsidiados (até o valor 1 imite de $30 \%$ das exportaçós do ano anterior, sem correção monetária e juros de $8 \%$ ao ano), operação $15 / 6$ do Banco do Brasil e adiantamentos sobre contratos de câmbio;

- Créditos de IPI e ICM incidentes sobre as ex portações, conforme deliberado pela Portaria no 73 do Ministé rio da Fazenda de 31 de dezembro de 1978;

- Isenção de Imposto de Renda sobre a parcela das vendas relativas à exportação que nas principais empresas do setor atinge sua quase totalidade cerca de $90 \%$; e

- Isenção de Imposto de Renda para equipamen tos no valor de até $10 \%$ do incremento anual do valor das exportações obtido no ültimo ano em relação ao anterior (Decreto Lei n? 1.189)" BNDE (1978).

Observa-se pela tabela 07 , o crescimento da participação dos derivados de cacau, na exportação total de cacau, especialmente a partir de 1976. Tal tendência deve-se à intensificação no Brasil de instalações de fábricas de pro dutos derivados, levando o país a exportar o produto, cerca de $50 \%$ na forma "in natura" e $50 \%$ na forma de derivados de cacau (manteiga de cacau, massa de cacau ou liquor, torta de cacau e cacau empó).

A maior parte do volume exportado pelo Brasil de cacau em amêndoas segue para os Estados Unidos, Países

6/ Para maiores detalhes sobre estes aspectos, vide Brandão A.L.A., Politi cas Econômicas e seus Efeitos no Desempento da Economia Cacaueira 19501980, USP-ESALQ, (Tese de Mestrado), 1983. 
Tabela 07. Exportação Brasileira de Cacau em Amêndoas e Deriva dos e Participação Percentual

$1963-1982$

1.000 Toneladas

Cacau em Améndoas e
Deriondo Derivados (EIA) a/
Cacau en Relação Cacau efn Amêndonas

Anêndoas na Exportação Total de Cacau
Derlvados

de Carnu, (ETA)
Relacain Cerlvahos de Caraus in.

Exportação Tutal de Cacaus

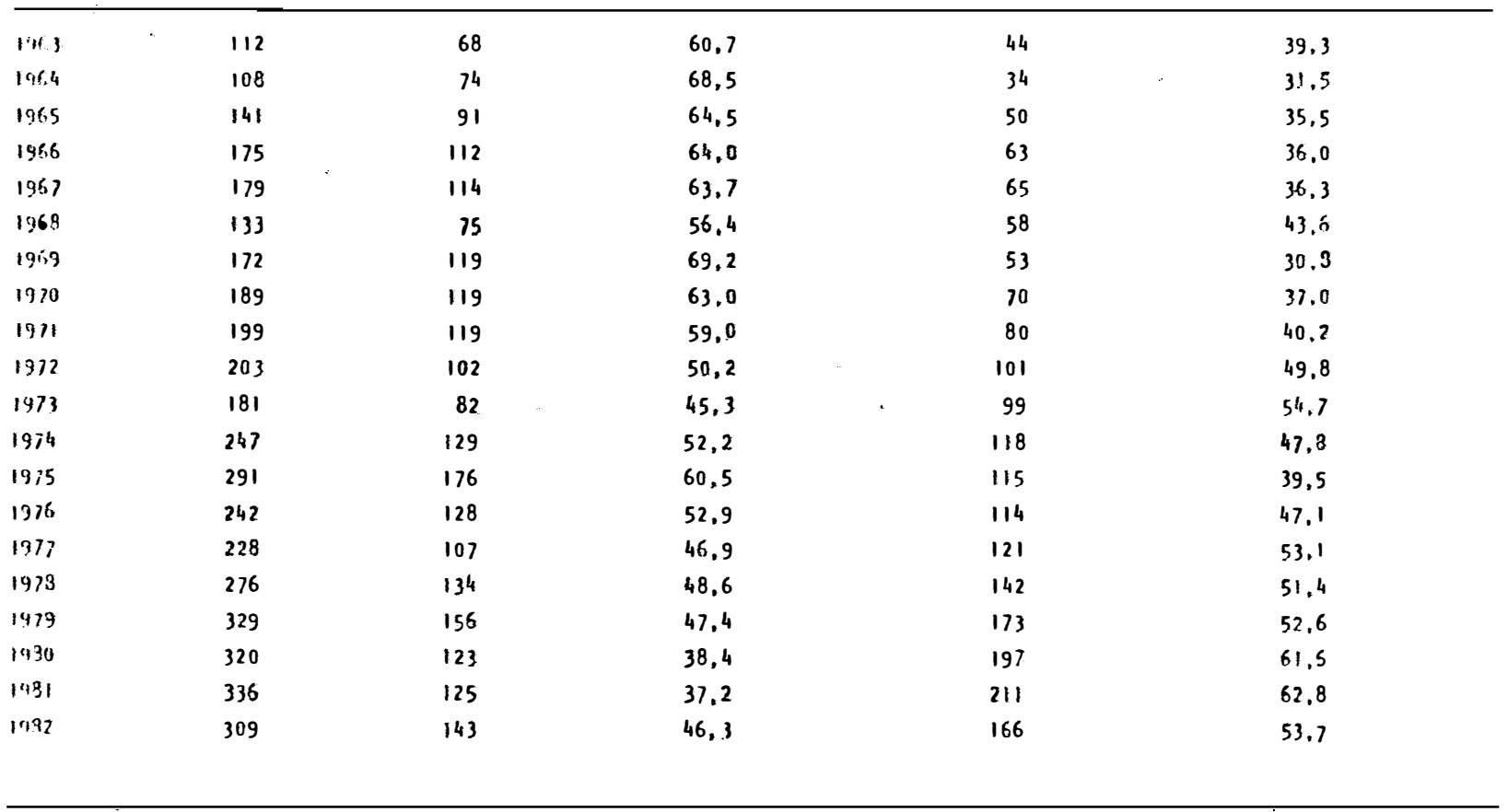

a/ Derivados em termos de amēndoas (ETA) - Fatores de conversão: massa de cacau - 1,2498, manteiga de cacau - 2,6586.

Fonte: Dados Preliminares - Comércio Exterior Brasil - Banco do Brasil CACEX - 1963 - 1982 .

Brasil Exportação - Banco do Brasil - CACEX - 1975 - 1982. 
Baixos, Reino Unido, Alemanha Ocidental, Polônia, União Sovié tica entre outros.

No período analisado, 1963-1982, observa-se o crescimento da exportação brasileira de cacau em amêndoas pa ra os países do bloco socialista, Polônià e União Soviética, resultante do incremento do intercâmbio comercial com os pai ses do leste europeu (Tabela 08 ).

A receita cambial brasileira com as exporta ções de cacau em amêndoas e derivados cresceu ao longo do periodo 1963-1979 (Tabela 09), sendo que o valor das exporta ções brasileira de cacau em amêndoas e derivados em 1979 atin giu o recorde de 952 milhöes de dólares, receita esta favore cida pelos altos preços vigentes no periodo 1976-1979. A par ticipação das exportações de cacau em amêndoas e derivados re presentava, em 1969, $6 \%$ do valor das exportacões brasileira. Essa participação decresceu no período 1970-1976, o que pode ser atribuída à diversificação na pauta das exportações brasi leira. No período de 1977-1979, a participação nas exporta ções de cacau no valor das exportações brasileira manteve-se superior a $6 \%$, decrescendo drasticamente nos três anos poste riores, atingindo $2,16 \%$ em 1982. Os baixos preços do cacau a partir de 1980 provocaram a queda das receitas de exportação do produto e consequentemente o decréscimo na participação das exportações brasil leira.

os maiores países importadores de cacauem amên doas são Estados Unidos, Alemanha Ocidental, Países Baixos, União Soviētica, Reino Unido, Itälia, França, Espanha e Bél gica. Nesses países estão localizadas diversas fábricas de chocolate, sendo que o elevado consumo per capita de chocola te nesses países os colocam como os maiores importadores mundiais de cacau em amêndoas. 0 consumode chocolate é favorecido 


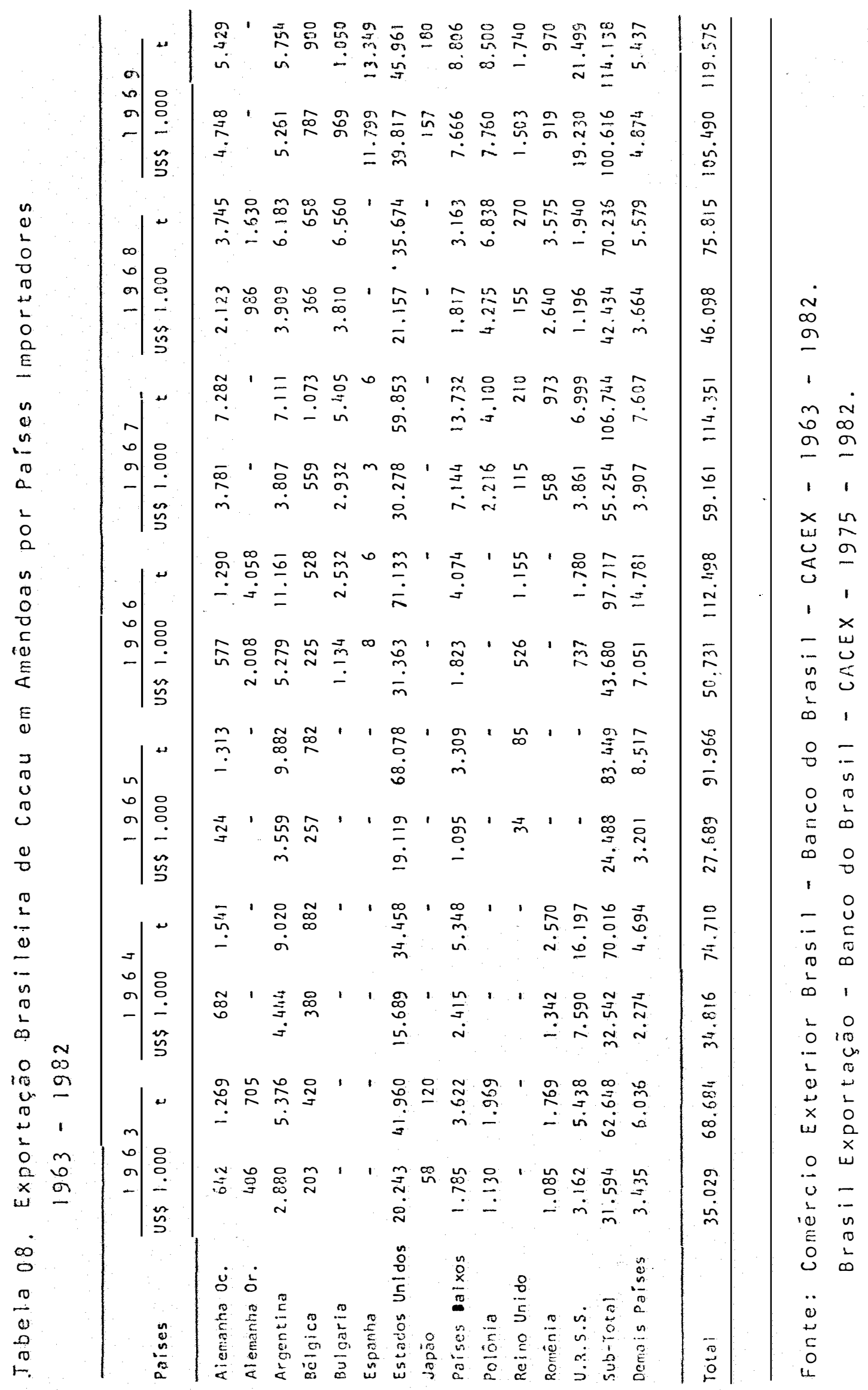




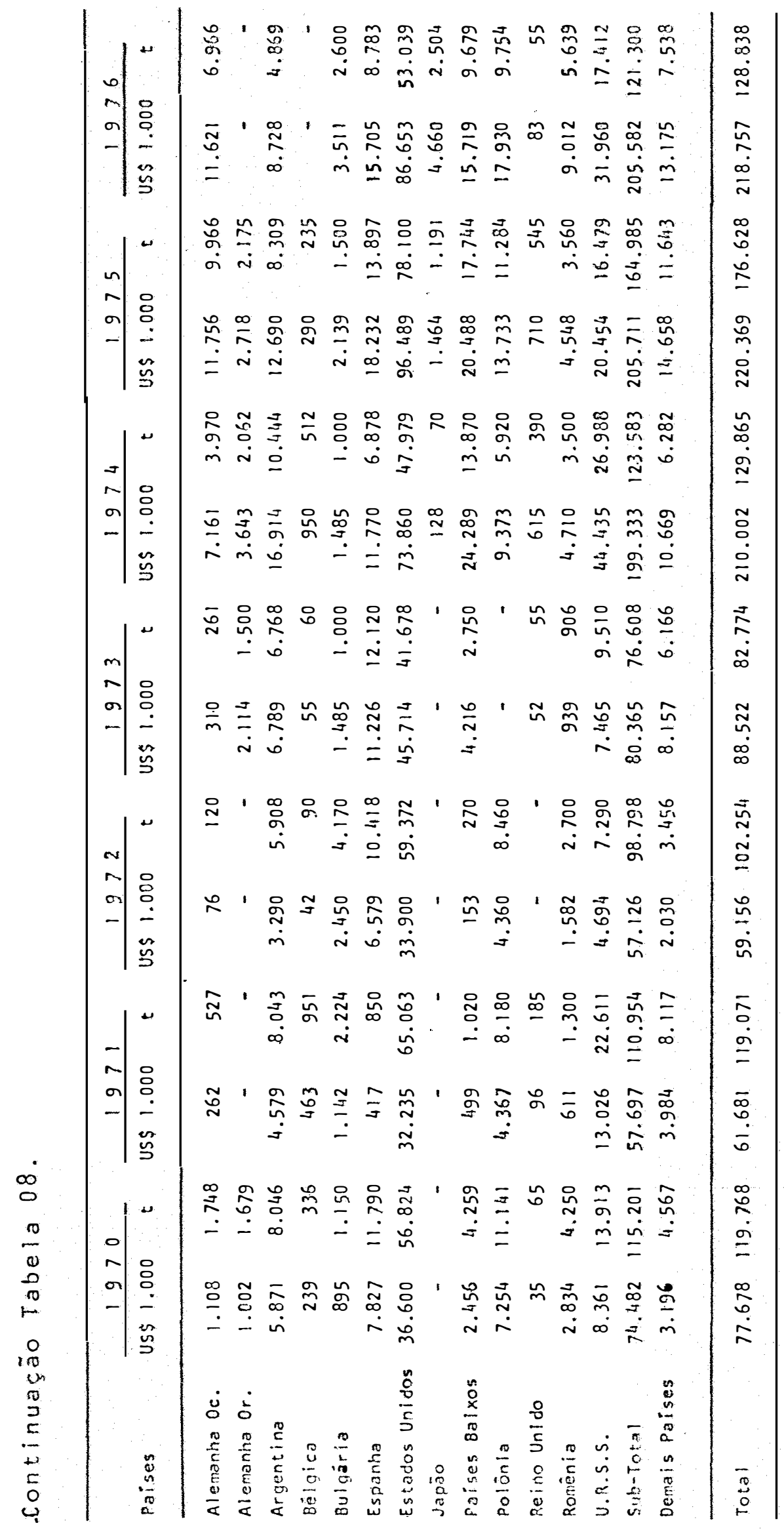




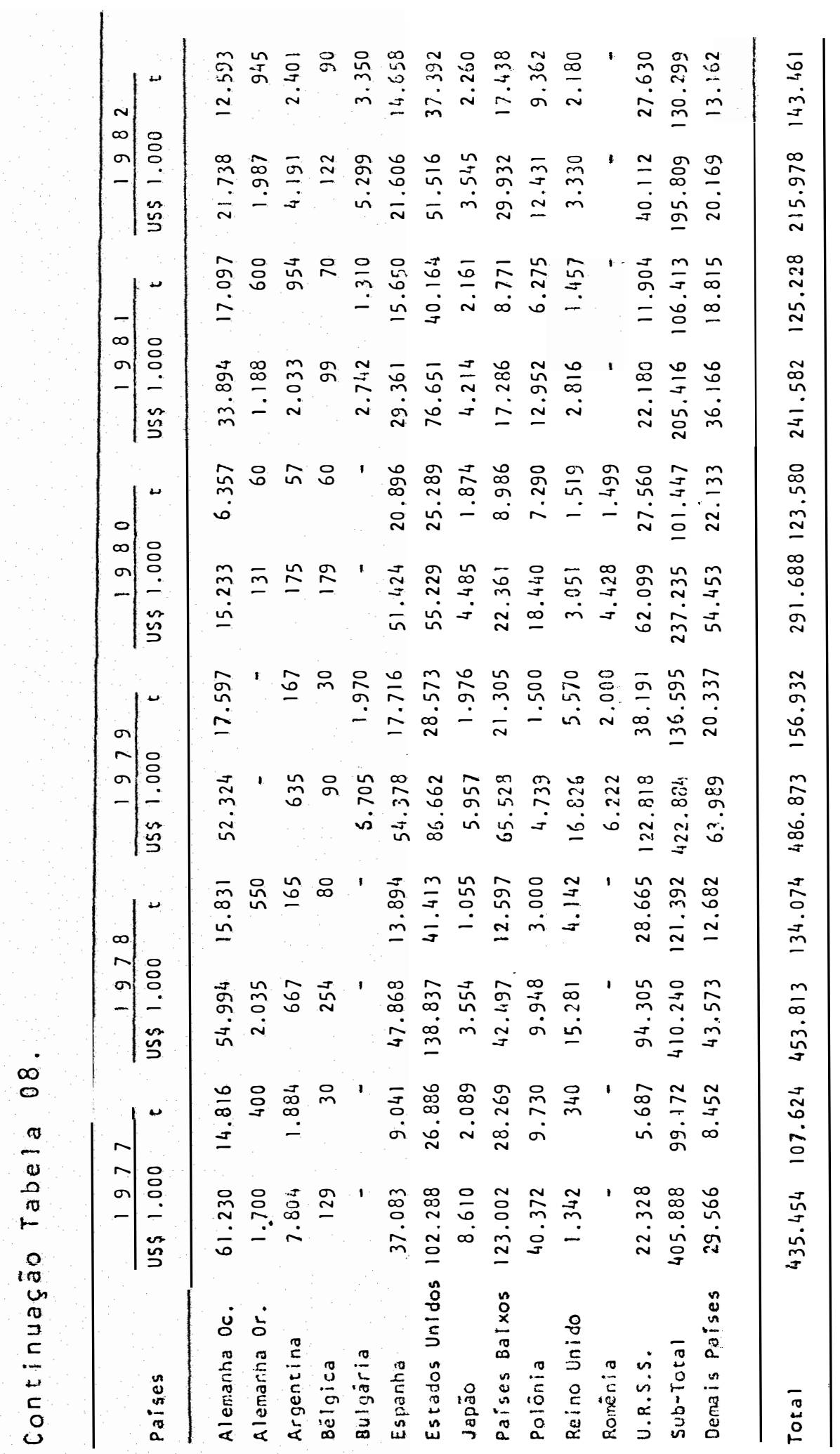




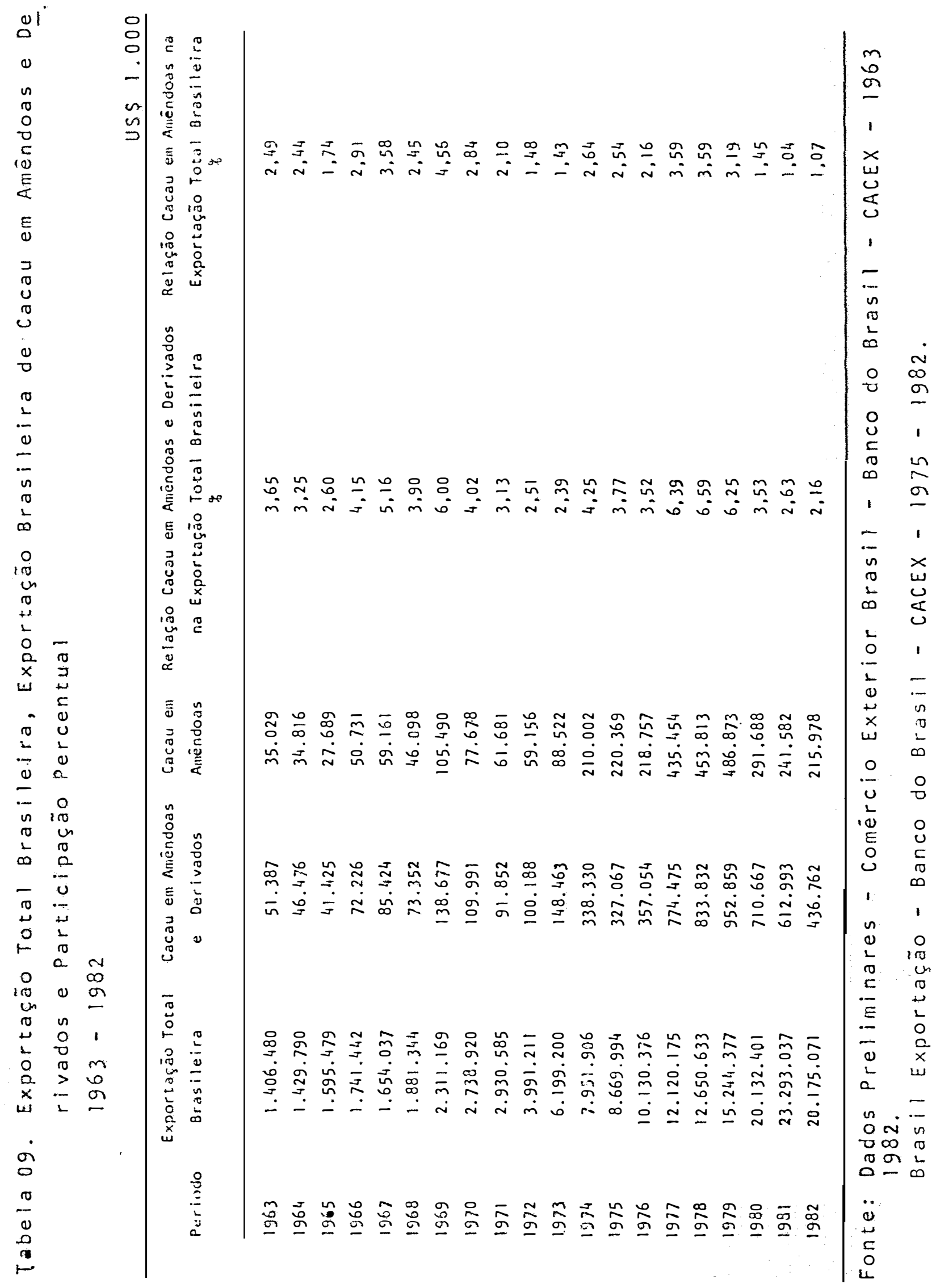


pela tradição, valor nutritivo do produto, além do clifie frio e temperado.

Observa-se pelos dados da Tabela 10 , uma tendên cia de queda nas importações de cacau em amêndoas pelos Estados Unidos, ltália e Bélgica, o que pode ser atribuído a uso de sucedâneos da manteiga de cacau na fabricação do chocolate. Nos ültimos anos o uso de sucedâneos da manteiga de cacau, en tre eles "Shea Butter", "lllipée", öleo de dendê e olëo de palmiste, tem aumentado devido principalmente aos elevados pre ços do cacau que prevaleceram no período 1977-1979. A alta de preços do produto levou determinados países a investirem em novas instalações industriais para o uso de sucedâneos.

Após ciclos de alta e baixa de preços, esia 1960 , o mercado internacional do cacau volta à instabilidade. A par tir deste ano, são frequentes às negociações entre países pro dutores e consumidores para implementação do Acordo Interna cional do Cacau, visando a estabilidade dos preços. A sendên cia de queda nos preços permaneceu até 1965 devido aos exce dentes de produção mundial de cacau. De 1966-1969 ocorreu au mento nos preços em decorrência da queda da produção rindial de cacau. Neste período, as moagens excederam à produçä́, ge rando uma situação de dêficit. 0 declínio acentuado da produ ção mundial de cacau, de $1,493 \mathrm{mil}$ toneladas em 1964/1965 para 1,214 mil toneladas em 1965/1966, deve-se a problemas cli māticos, como a seca na Costa do Marfim, Gana e Nigérià lîbe la 11).

No período de 1970-1972, há nova queda de pre ços no mercado internacional de cacau, em consequência do au mento da produção mundial do produto a taxas bem mais eleva das do que as do consumo. A partir de 1973, a tendência se inverte ocorrendo grandes elevações de preços no nersado 


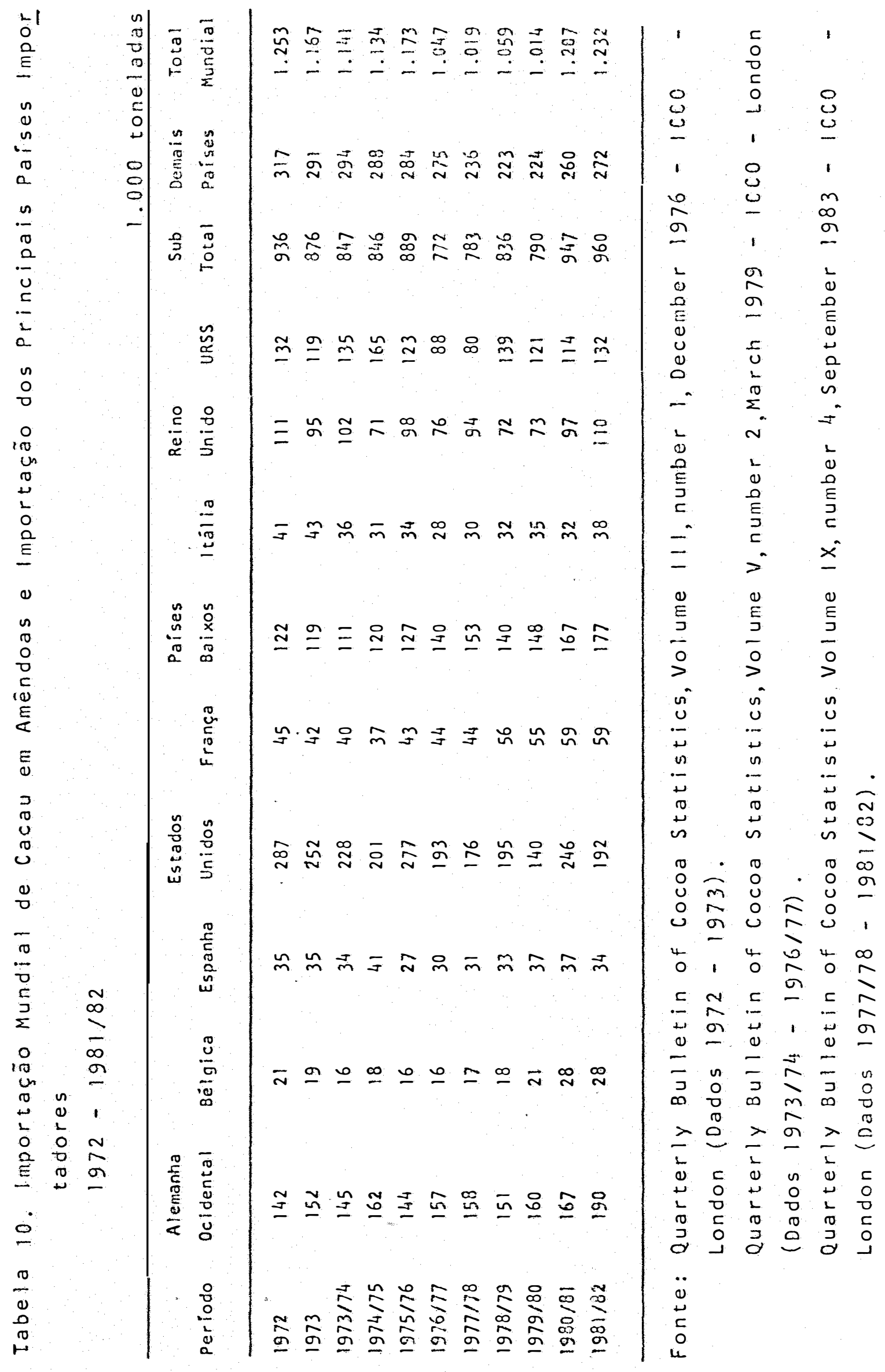


externo, sendo que neste ano, estava em vigor o lo Acordo In ternacional do Cacau de 1972, o qual não teve atuação, uma vez que os preços do cacau no mercado externo, permaneceram acima dos preços 1 imites estabelecidos no Acordo. A taxa anual mé dia de crescimento dos preços de cacau no período 1963-1982 foi de $2,55 \%$ para cacau em amêndoas e derivados, 2,59\% paraca cau em amêndoas e $3,22 \%$ para os derivados (Tabela 05). Os ele vados niveis de preços verificados no período, devem-se à ex cassez de oferta do produto no mercado mundial e à expansão econômica dos países industrializados.

A expansão econômica dos países industrializados levou ao aumento significativo do consumo de cacau e, por outro lado, os países produtores não puderam acompanhar em ter mos de aumento de produção, uma vez que a cultura do cacau é de ciclo longo, respondendo a longo prazo os incentivos de preços. Cabe salientar a queda da produção de cacau em Gana, que durante muitos anos ocupou o primeiro lugar como produtor mundial do produto. o declínio da produção de cacau em Gana deve-se especialmente à instabilidade política e aos baixos preços pagos aos produtores.

A situação favorävel de preços no mercado in ternacional levou alguns países a investirem maciçamente no aumento da produção de cacau. Brasil e Costa do Marfim cria ram Programas Especiais de expansão da produção de cacau. 0 Brasil criou o Programa de Expansão da Cacauicultura-PROCACAU, instituido em 1976, que tinha como meta a implantação de 300 mil hectares de cacaueiros novos e a renovação de $150 \mathrm{mil}$ hec tares. I/ Além dos preços favoráveis no mercado internacional, outros fatores parecem ter contribuido para a implantação do PROCACAU, dentre os quais destacam-se o desenvolvimento de

IJ Em 1982 houve modificação nas metas passando a implantação para 245,8 mil hectares e a renovação para $69,1 \mathrm{mil}$ hectares. 
novas tecnologias pelo Centro de Pesquisas do Cacau - CEPEC, subsidios e financiamento dado pelo governo aos produtores e as indústrias processadoras.

Os altos investimentos na década de 70 para a expansão da produção de cacau levaram, a partir de 1980 , à elevação dos excedentes de produção e, consequentemente, à re dução de preços. Um dos sërios problemas enfrentados pelos pro dutores mundiais de cacau nos ültimos anos, é o aumento per sistente dos estoques mundiais do produto. Os estoques fi nais, que em 1980/1981 eram de $556 \mathrm{mil}$ toneladas, passaram a $666 \mathrm{mil}$ toneladas em 1981/1982. Outrossim, a variação do esto que - estoque final menos estoque inicial, tem sido positiva nos ültimos cinco anos agravando as flutuaçöes de preços (Ta bela 11).

A situação de excesso de produção de cacau no mercado mundial, a partir de 1980 , os baixos preços vigentese a falta de consenso entre países produtores e consumidores pá ra a implantação imediata do 39 Acordo Internacional do Cacau, contribuiram ainda mais, para o declínio dos preços do produ to no mercado internacional.

No tocante aos estoques de cacau, destaca-se que os países consumidores de cacau fazem a estocagem do pro duto. Sendo o cacau um produto perecível, sua estocagem por um periodo de tempo mais longo se verifica nos países de cli ma frio e temperado. Alguns paísés produtores estão investindo para melhorar as condições de estocagem em clima tropical. o produto a ser estocado deve ser na forma de derivados de cacau, uma vez que a estocagem do cacau em amêndoas é mais sensivel à perecibilidade. No Brasil, algumas indústrias de derivados de cacau já possuem capacidade para estocar o pro duto. 


\section{5}

Iabela 11. Balanço Riundial da Cferta e Demanda de Cacau em Amêndoas

$$
1960 / 61-1581 / 82
$$

\begin{tabular}{|c|c|c|c|c|c|c|c|}
\hline Perlodo & $\begin{array}{l}\text { Is inque } \\
\text { Iniciol }\end{array}$ & $\begin{array}{l}\text { Total (stuto) ed } \\
\text { Produção Mundial }\end{array}$ & $\begin{array}{l}\text { Toial (Liquidol da } \\
\text { Procução Kundial gl }\end{array}$ & $\begin{array}{c}\text { Oisponibilidade } \\
\text { Tolal }\end{array}$ & Hoagens & $\begin{array}{l}\text { Esionue } \\
\text { Final }\end{array}$ & $\begin{array}{l}\text { Variaçào do } \\
\text { Estoque }\end{array}$ \\
\hline $1960 / 61$ & 385 & 1.189 & 1.177 & 1.562 & 1.000 & 562 & +177 \\
\hline $1961 / 62$ & 562 & 1.140 & 1.129 & 1.691 & 1.095 & 596 & +34 \\
\hline 1962163 & 596 & 1.176 & 1.164 & 1.760 & 1.144 & 616 & +20 \\
\hline 1963164 & 616 & 1,234 & 1,222 & 1.838 & 1.184 & 654 & $+\quad 38$ \\
\hline $1964 / 65$ & 654 & 1,508 & 1,493 & 2.147 & 1.297 & 845 & +191 \\
\hline $1965 / 66$ & 845 & 1.226 & 1.214 & 2.059 & 1.374 & 685 & -160 \\
\hline $1986 / 67$ & 685 & 1.351 & 1,337 & 2.022 & .1 .387 & 635 & -50 \\
\hline 1957168 & 635 & 1.354 & 1,340 & 1.975 & 1.403 & 572 & -63 \\
\hline $1968 / 69$ & 572 & 1.242 & 1,230 & 1.802 & 1.363 & 433 & -139 \\
\hline $1.969 / 70$ & 433 & 1.435 & 1.421 & 1.854 & 1.354 & 500 & $\begin{array}{l}+67 \\
+\quad 6\end{array}$ \\
\hline $1970 / 71$ & 500 & 1,499 & 1.484 & 1,984 & 1.399 & 585 & +85 \\
\hline $1971 / 72$ & 585 & 1.583 & 1.567 & 2,152 & 1.536 & 616 & +31 \\
\hline $1972 / 73$ & 616 & . $\quad 1.397$ & 1.383 & 1.999 & 1.583 & 416 & -200 \\
\hline $1973 / 74$ & 416 & 1.448 & 1.434 & 1.850 & 1.512 & 338 & -78 \\
\hline $1874 / 75$ & 338 & 1.549 & 1.534 & 1.872 & 1.452 & 420 & +82 \\
\hline $1975 / 76$ & 420 & 1.512 & 1,497 & 1.917 & 1.523 & 394 & -26 \\
\hline $1976 / 77$ & 394 & 1.338 & 1,325 & פו7.7 & 1.442 & 277 & $-\quad 117$ \\
\hline $1977 / 78$ & 277 & 1.503 & 1,488 & 1.765 & 1.399 & 366 & $\begin{array}{l}+\quad 89 \\
+\end{array}$ \\
\hline $1978 / 79$ & 366 & 1.489 & 1,474 & 1.840 & 1.459 & 381 & +15 \\
\hline $1979 / 80$ & 381 & 1.622 & 1.606 & 1.987 & 1.489 & 498 & +117 \\
\hline $1980 / 81$ & 498 & 1.664 & 1,647 & 2. 145 & 1.589 & 556 & $+\quad 58$ \\
\hline $1981 / 82$ & $556^{c}$ & $1.726^{c}$ & $1.709^{c}$ & $2.265^{c}$ & $1.559^{c}$ & $666^{c}$ & $+110^{c}$ \\
\hline
\end{tabular}

a/ Considerando $1 \%$ de perda na produção mundial bruta.

b/ Moagens mundial excluindo $5 \mathrm{mil}$ toneladas de cacau em amên doas, vendidas para uso não tradicional, as quais, deduzi das dos estoques.

c/ Estimativa

* Disponibilidade total = estoque inicial mais a produçãomun dial liquida.

Fonte: Gill \& Duffus Cocoa Market Report, n? 309, october 1983. 
A vulnerabilidade dos países produtores de ca cau diante dos países consumidores, pode ser atribuida a fal ta de condições apropriadas para estocagem do produto, tendo, como consequência, a predominância dos países consumidores na comercialização mundial de cacau em amêndoas e derivados e a fragilidade dos países produtores nas negociações dos Acordos Internacionais de Cacau.

o consumo brasileiro de cacau possui caracte ristica distinta. 0 cacau è um produto altamente voltado para o mercado externo, sendo o consumo interno reduzido. As indústrias chocolateiras, em sua maioria, adquirem o cacau em amêndoas, que depois de processado é utilizado para seu prō prio consumo, na confecção do produto final-chocolate. 0 con sumo interno de cacau, situando-se em torno de $10 \%$ da produ ção nacional de cacau, é considerado baixo, dado que o Brasil ocupa o 29 lugar como produtor mundial de cacau.

Desde a década de 70 , uma sērie de campanhas estão sendo desenvolvidas atravēs do Comite Nacional de Expan são do Consumo Interno do Chocolate-CONEC, para incentivar o consumo brasileiro de chocolate. Cabe salientar que, embora o consumo interno do produto acabado venha aumentando, as campa nhas de promoção do consumo, provavelmente surtirão efeitos significativos no médio e longo prazo. As razões para se acre ditar na presença de limites a tal crescimento são o nivel de renda da população, a crendice nos efeitos prejudiciais do chocolate à saúde, o que contribui para manter o consumo do produto a nivel de guloseimas e a diversificação de costumes que naturalmente correspondem ao extenso território onde a po pulação se espalha produzindo padrões diferenciados de consu mo. Nesse sentido, a maior demanda se concentra nas regióes sul e sudeste, provavelmente devido ao nivel de renda, a per cepção do püblico dos valores proteicos do chocolate, atitudes 
essas reforçadas pelo clima mais temperado, que impedem

uma associação ilógica de idéias relativas ao produto.

A expansão do setor de produtos acabados leva ria a um maior consumo interno da produção cacaueira, o que resultaria em maiores retornos na exportação de cacau em amẽn doas e derivados, pela redução da oferta no mercado externo, alēm de ser uma alternativa para reduzir a instabilidade de preços no mercado internacional.

3.1.1. Grau de concentração das exportaçõesbrasileira de cacau em amêndoas.

Observa-se na Tabela 12 o indice de Gini para cacau em amêndoas. No período 1963-1966, o grau de concentra ção para cacau em amêndoas apresenta-se elevado, diminuindo a concentração entre 1967-1970, tal mudança pode ser atribuída ao aumento das exportações dos derivados de cacau, que a par tir deste período, aumentaram de modo significativo, a parti cipação no valor das exportações brasileira de cacau. Em ge ral, o grau dé concentração do valor das exportações de cacau em amêndoas se apresenta menos concentrado a partir de 1974 , esta menor concentração deve-se à politica brasileira adotada na década de 70 , objetivando incrementar as exportações de produtos semi-industrializados, no caso do cacau, dos deriva dos de cacau. A politica de industrialização, levou a amplia ção significativa do parque industrial brasileiro e consequen temente ao aumento das moagens de cacau. Salienta-se ainda, a politica de subsidios aos derivados de cacau, que tinha como uma das finalidades. compensar as tarifas protecionistas adota das pela CEE.

Constata-se a concentração das exportações 
Tabela 12.. Tndice de Gini: Cacau em Amēndoas (Valor das Ex portaçōes Brasileira por Paises Importadores). $1963-1982$

\begin{tabular}{lccc}
\hline Periodo & cacau & Periodo & cacau \\
\hline 1963 & 0,73 & 1973 & 0,71 \\
1964 & 0,74 & 1974 & 0,62 \\
1965 & 0,84 & 1975 & 0,64 \\
1966 & 0,78 & 1976 & 0,59 \\
1967 & 0,68 & 1977 & 0,62 \\
1968 & 0,62 & 1978 & 0,63 \\
1969 & 0,62 & 1979 & 0,58 \\
1970 & 0,65 & 1980 & 0,59 \\
1971 & 0,75 & 1981 & 0,60 \\
1972 & 0,74 & 1982 & 0,54 \\
\hline
\end{tabular}


brasileira de cacau ern amêndoas para os mercados tradicionais (Tabela 08): Alemanha 0cidental, Estados Unidos, Países Baixos, Polónia, Reino Unido, União Soviética entre outros. En tretanto, a menor concentração nos ültimos anos, poderia es tar associada à conquista pelo Brasil de novos mercidos. As indicações levam a crer, que não houve conquista de novos mer cados pelo Brasil, mas, o aumento da demanda emalguns pa ses compradores, notadamente União Soviética, AMIN (1984).

\subsection{Mercado Internacional de Café}

O Brasil, que por muitos anos foi praticamente o único país produtor de café, mantém até hoje posição de mai or produtor mundial. Cerca de $74 \%$ da produção mundial de café provem do Brasil, Colómbia (2ọ produtor mundial de café), Mé xico, Costa Rica, El Salvador, Guatemala, Indonésia, Angola, Costa do Marfim e Uganda. A produção brasileira de café em $1964-1965$ alcançou $498 \mathrm{mil}$ toneladas, o declínio da produção deve-se às geadas de agosto/setembro de 1963 e ao plano de er radicação e diversificação da safra cafeeira, que teve inicio em 1962 (Tabela 13). No período analisado, 1962/1963-1980, a menor produção brasileira de café verificou-se em 1975/1976, $400 \mathrm{mil}$ toneladas, sendo que o novo decréscimo da produção foi provocado pelas geadas ocorridas no sul do país em 1975 .

A participação do Brasil na produção mundial de café em $1962 / 1963$ era de $41,53 \%$, enquanto que no mesmo perío do, a participação da colômbia era de $10,78 \%$. A rápida expansão da cafeicultura na Colômbia fez com que a sua participa çäo aumentasse para 17,09\% em 1980 (Tabela 14).

A taxa anual média de crescimento da produção brasileira de café cru em grãos foi de $-0,15 \%$, devidoem parte 


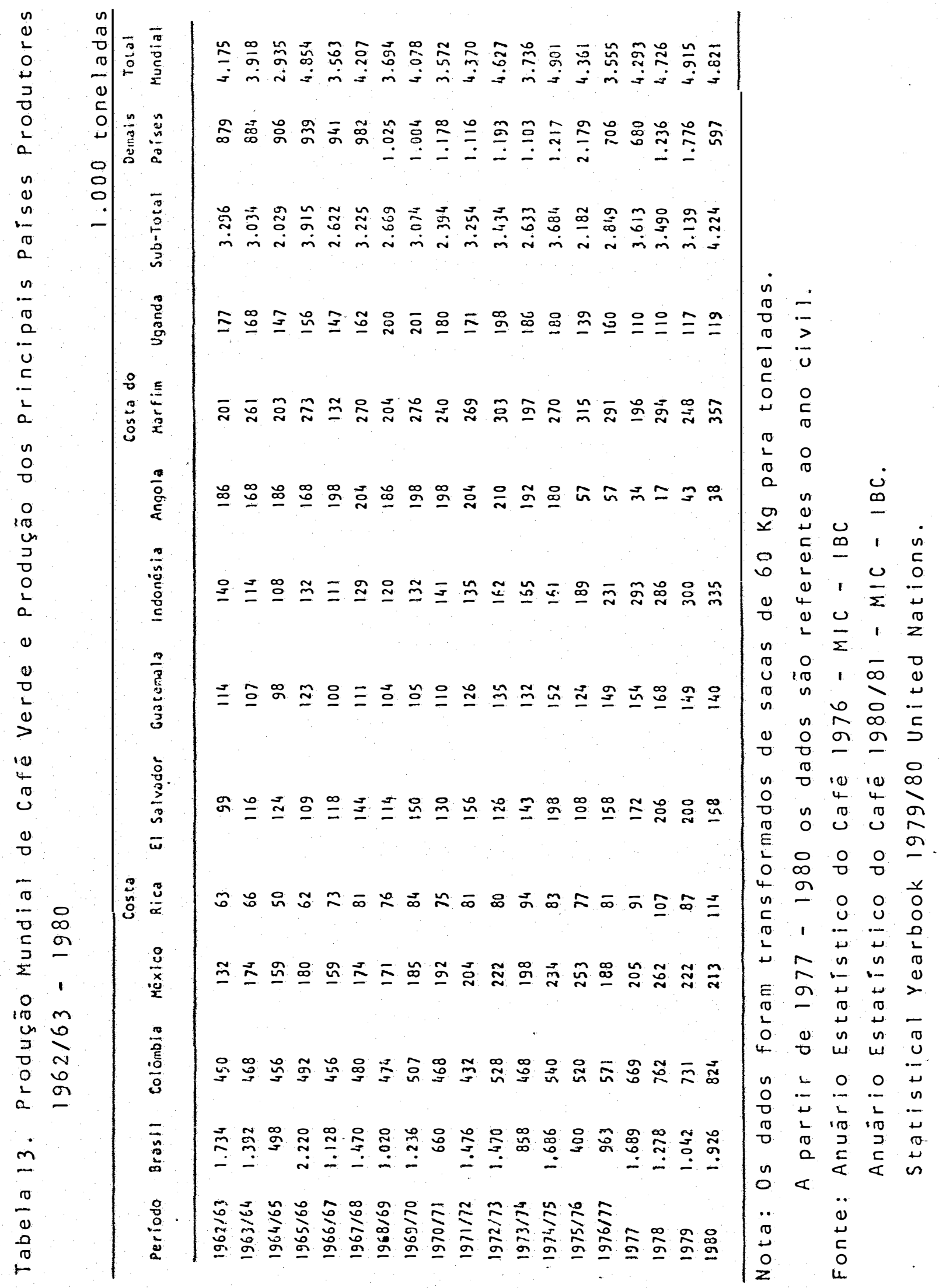




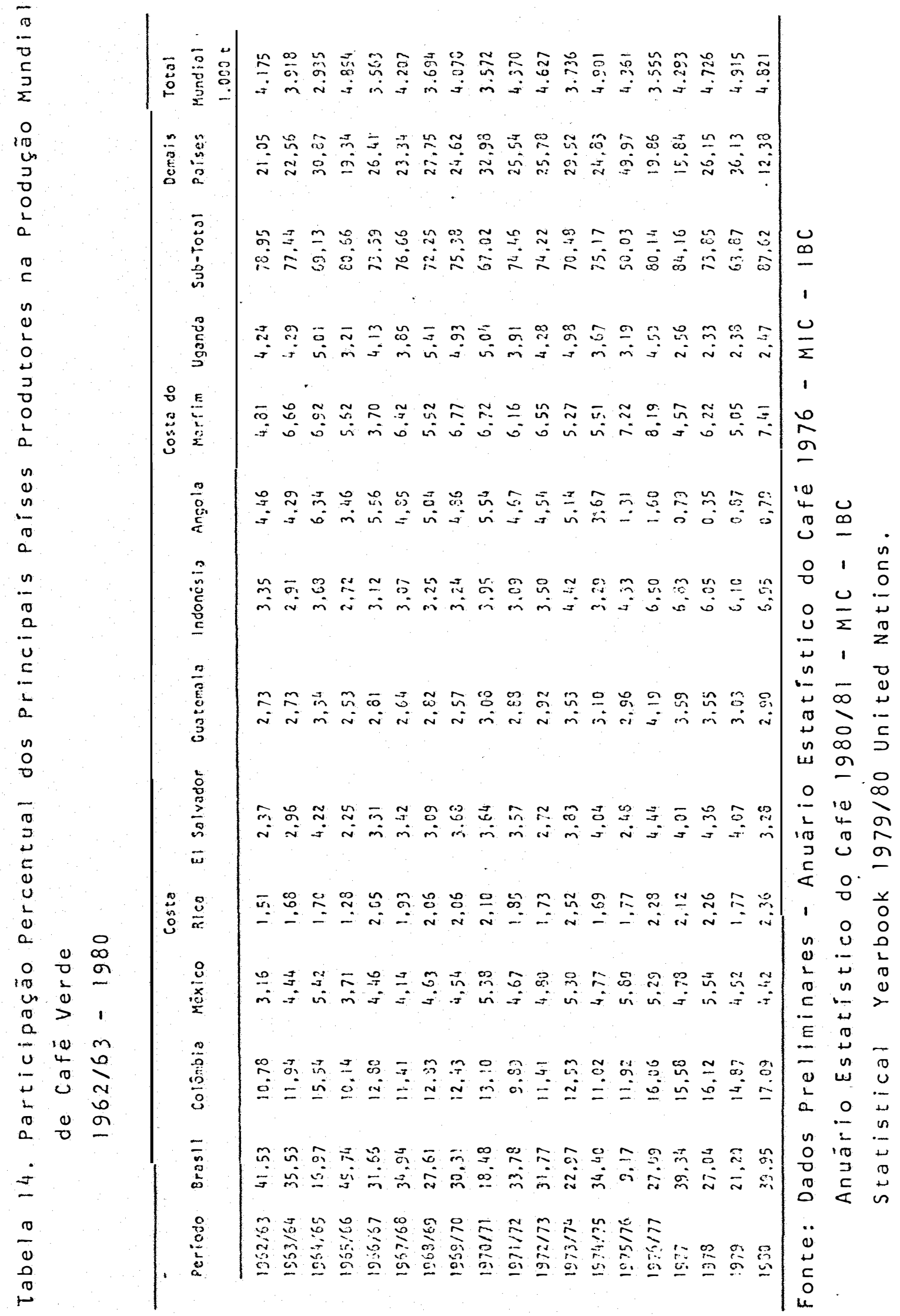


às frequentes geadas ocorridas no periodo, especialmente nos anos de 1963 e 1975. Por outro lado, os elevados estoques do produto provocaram a decisão do governo de destruir aproximadamente 78 milhões de sacas de café e de implantar o plano de erradicação da lavoura cafeeira em 1962, medidas estas que con tribuiram para a diversificação da lavoura brasileira.

A taxa anual média de crescimento das exportações de café crü em grãos e solūvel no período 1963-1981 foi de $-1,59 \%$, das exportações de café cru em grãos $-2,77 \%$, enquan to que a taxa anual média de crescimento das exportações de café solüvel atingiu 38,53\% (Tabela 15). A taxa de crescimento negativa da exportação de café cru em grãos deve-se, con forme citado anteriormente, ao plano de erradicação e divers ficação da lavoura cafeeira e à politica adotada durante mui tos anos pelo Brasil, de redução de suas exportações de café para manter favorável o nível de preços do produto, no merca do internacional. 0 elevado crescimento das exportações brasileira de café solúvel é devido a politica brasileira de in dustrialização, objetivando o aumento das exportações de pro dutos com maior valor agregado.

A indústria de solüvel recebeu incentivos finan ceiros e subsídios para sua implantação. Dado o crescimentodo consumo de café solúvel no mercado norte-americano, as autor dades brasileiras perceberam a necessidade de implantação de indüstrias de söluvel de grande capacidade no país. Em 1961 , a Diretoria do IBC, atravēs da Resolução 195, procurou incen tivar o setor privado para a instalação de fäbricas de café solúvel. Foram concedidos os seguintes subsídios:

$$
\text { - " } 300.000 \text { sacas de } 60 \mathrm{~kg} \text { de café por ano, nos }
$$

quatro primeiros anos, pelo preço de mercado interno na ëpoca do faturamento, retiradas dos estoques governamentais; 
Tabela 15- Taxa Geométrica Anual Média de Crescimento nos Pe ríodos 1962/63 - 1980, 1963-1981-Brasil

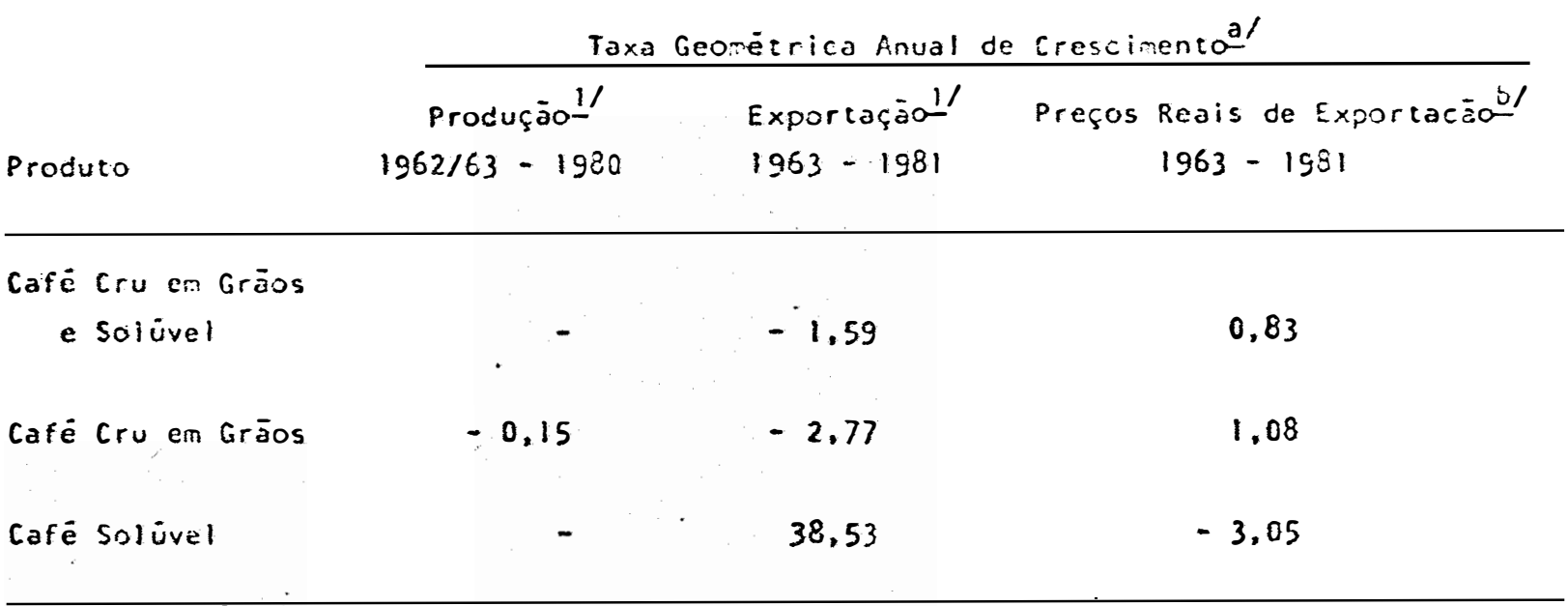

a/ Estimada através do ajustamento da regressão linear simples onde a variável independente è a tendência e a variāvel de pendente é o logarítimo dos valores observados das variä veis. Determinado o coeficiente de regressão (b) a taxa ge ométrica anual média (r) foi estimada atravēs da förmula $r=a n t i \log b-1$.

b/ Os preços fob das exportações brasileira de café crü em grãos e solüvel obteve-se dividindo o valor anual médio em dólar das exportações brasileira de café crü em gräos e so lúvel pelo volume em toneladas das exportações brasileira destes produtos.

Os preços em dólar por tonelada foram deflacionados pelo indice de preço no atacado dos Estados Unidos corrigidos, base $1982=100$.

Fonte:

1/ Anuärio Estatistico do Cafë 1976 e 1980/81-MIC-IBC. 
- o pagamento seria em 48 prestações mensais, iguais e sucessivas, a partir do 13 o mês do fornecimento in cial de cada período;

- O IBC acertaria o pagamento da matéria-prima fornecida no primeiro ano de atividade da empresa em produ tos manufaturados, embalado e dentro de certas outras condi ções;

- aplicação do sistema de "draw-back" nas ex portações de solüvel; e

- concessão de aval pelo governo, através de sua rede bancária ou financeira nos eventuais contratos de fí nanciamento para aquisição de equipamento pelas empresas que viessem a ser julgadas aptas" MACEDO (1968).

Entre os principais países exportadores de café destacam-se Brasil, Colômbia, El Salvador, Indonésia e Mé xico. A participação do Brasil nas exportações mundiais de ca fé em 1962 era de 35,4\%, decresceu para 19,2\% em 1979. Tal de créscimo deve-se a política brasileira de retenção das expor tações de café, com o objetivo de melhorar o nivel de preços no mercado internacional. Por outro lado, observa-se a cres cente participação nas exportações mundiais de café cru em grãos da Colómbia e Indonésia (Tabela 16). O Brasil por um lon go periodo, deteve o monopólio da produção de café, masos pre ços remuneradores do produto no mercado internacional, levaram diversos paises a investirem maciçamente na produção destacul tura.

Houve aumento nos preços do café a partir de 1964, devido às geadas no sul do Brasil em agosto e setembro de 1963. O declínio da produção brasileira teve grande repercussão na safra mundial de café em 1964/1965, dado a posição do país de maior produtor mundial. A tendência de alta de 
Tabela 16. Participação Percentual dos Principais Países Ex portadores nas Exportaçöes Mundiais de Café Cru em Grãos

$$
1962-1981
$$

\begin{tabular}{lccccccc} 
Pericido & Brasil & Colúmbia & El Salvador & Indonésia & Hexico & Demais Páises & $\begin{array}{c}\text { Total } \\
1.000 t\end{array}$ \\
\hline 1952 & 35,4 & 14,2 & 3,2 & 2,1 & 3,1 & 42,00 & $2.775,3$ \\
1963 & 39,9 & 12,5 & 3,2 & 2,0 & 2,5 & 39,37 & $2.334,3$ \\
1964 & 31,9 & 13,7 & 3,8 & 2,2 & 3,8 & 44,52 & $2.803,2$ \\
1955 & 30,0 & 12,6 & 3,7 & 4,0 & 3,0 & 46,75 & $2.698,1$ \\
1966 & 34,7 & 11,4 & 3,3 & 3,4 & 3,1 & 44,07 & $2.941,6$ \\
1967 & 34,5 & 12,1 & 4,0 & 4,4 & 2,6 & 42,35 & $3.013,1$ \\
1963 & 35,5 & 12,3 & 3,7 & 2,5 & 3,0 & 43,09 & $3.216,4$ \\
1959 & 36,2 & 12,0 & 3,5 & 3,0 & 3,0 & 42,35 & $3.251,7$ \\
1970 & 32,4 & 12,3 & 3,5 & 2,7 & 2,7 & 46,31 & $3.163,3$ \\
1971 & 34,4 & 12,3 & 3,2 & 2,1 & 3,0 & 45,01 & $3.209,3$ \\
1972 & 33,2 & 11,3 & 3,6 & 2,4 & 3,0 & $4,6,53$ & $3.471,9$ \\
1973 & 31,7 & 10,8 & 4,0 & 2,6 & 3,7 & 47,23 & $3.755,0$ \\
1974 & 24,2 & 12,6 & 4,7 & 3,3 & 3,6 & 51,64 & $3.287,2$ \\
1975 & 25,2 & 14,1 & 5,3 & 3,7 & 4,1 & 47,51 & $3.474,7$ \\
1976 & 26,5 & 10,7 & 4,5 & 3,6 & 4,7 & 49,99 & $3.528,3$ \\
1977 & 21,6 & 11,3 & 6,4 & 5,3 & 3,8 & 51,61 & $2.830,0$ \\
1978 & 22,4 & 16,1 & 4,2 & 6,2 & 3,5 & 47,71 & $3.368,7$ \\
1979 & 19,2 & 17,8 & 5,4 & 5,8 & 4,8 & 47,10 & $3.757,2$ \\
1930 & 25,5 & 18,7 & 4,9 & 6,0 & 3,7 & 41,18 & $3.552,7$ \\
1931 & 26,4 & 15,0 & 3,6 & 6,1 & 3,3 & 45,61 & $3.632,8$
\end{tabular}

Fonte: Dados Preliminares - Anuário Estatistico do Café 1976 $M I C-I B C$

Anuário Estatístico do Café 1980/81 MIC - IBC. 
preços vigorou apenas por dois anos, 1964 e 1965 , pelo fato da situação do mercado cafeeiro não ser de dēficit. Mesmo apös a redução da safra brasileira, havia volumosos estoques mun diais de café. Assim, os preços do café declinaram até 1968 , como consequência dos excedentes de produção e contínua redu ção do consumo mundial, especialmente nos Estados Unidos.

No final da década de 60 , problemas climáticos adversos, a ferrugem e a broca do cafeeiro, provocaram redução na produção brasileira de café. 0 volume produzido de ca fé em 1970/1971 foi de $660 \mathrm{mil}$ toneladas, resultando na elevação dos preços do produto. Só foi possível ao Brasil aten der seus compromissos externos e consumo doméstico devido aos estoques brasileiros de café. Em 1972, o governo federal instituiu o Plano Trienal de Renovação e Revigoramento da Cafeicultura visando a expansão da produção. No entanto, a forte geada no sul do país em 1975 novamente levou à redução da sa fra brasileira de café, que em $1975 / 1976$ atingiu apenas 400 mil toneladas. Os preços do produto no mercado internacional aumentaram significativamente.

De modo geral, os estoques mundiais de café de cresceram de 1969/1970-1978/1979 quando atingiram o menor ní vel (Tabela 17). No ano seguinte, os estoques mundiais voltaram a crescer. Os aumentos na produção mundial de café não es tavam sendo acompanhados por aumentos no consumo e nas exportações, os quais mantinham-se relativamente estäveis. Neste contexto, os preços do café no mercado internacional mant $\mathbf{i}$ nham-se ainda a níveis favorāveis, o que pode ser atribuído a atuação do Acordo Internacional do Café e ao Grupo de Bogotá que intervinha no mercado com o objetivo de manter os preços.

Em 1981, os preços do café declinaram devido ao excesso de produção. A safra brasileira de café em 1980 
Tabela 17. Balanço Mundial da Oferta e Demanda de Café $1963 / 64-1981 / 82$

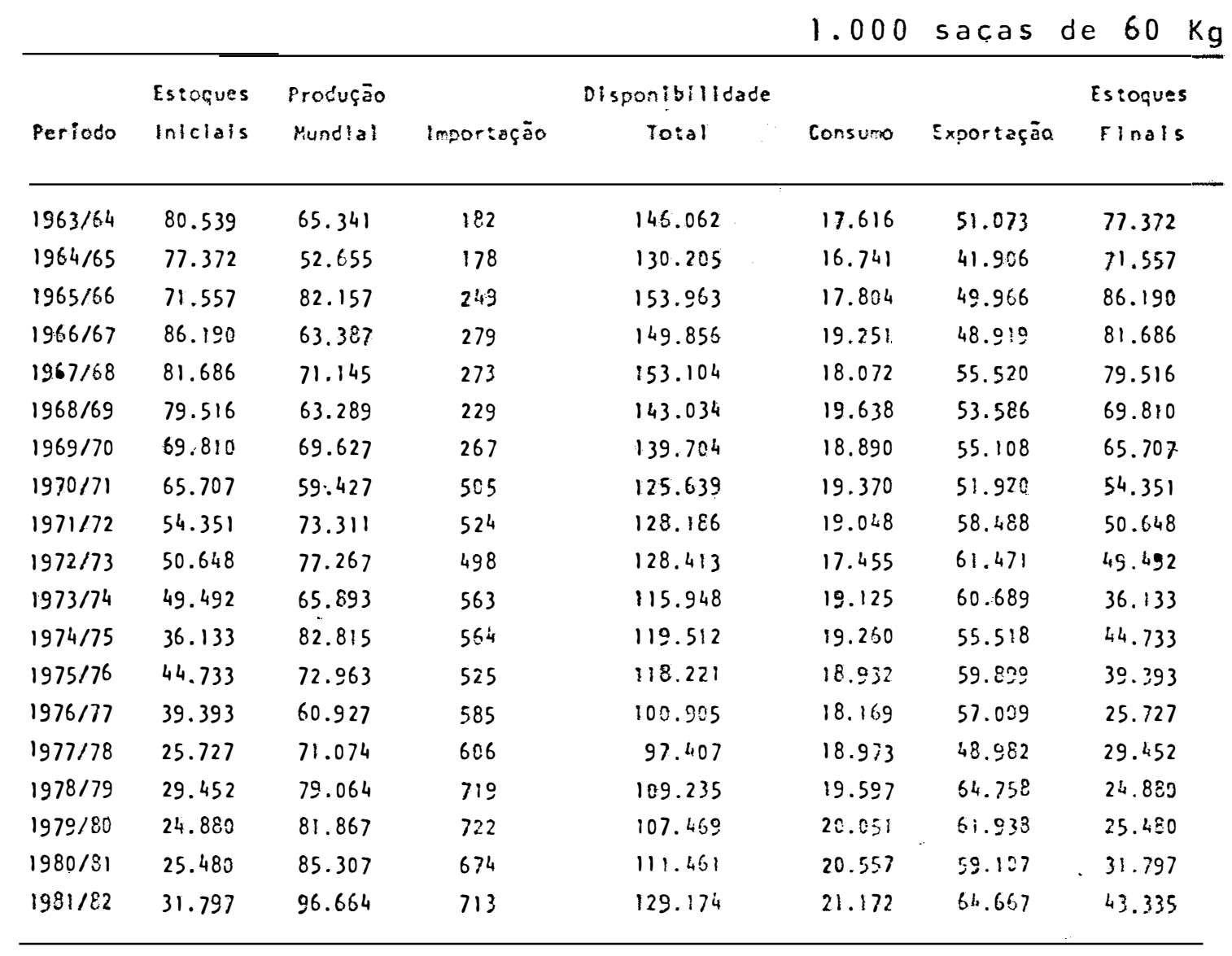

Fonte: Anuārio Estatístico do Café 1980/81-MIC - IBC. 
atingiu aproximadamente 2 milhões de toneladas, sendo que es sa expansão significativa da produção não foi absorvida, pelo mercado, uma vez que, tanto o consumo como as exportações man tinham-se relativamente estäveis. Mesmo as geadas ocorridas em meados de 1981 não foram suficientes parafrear o declí nio dos preços do café, dada a existência de elevados estoques mundiais do produto.

As condições de estocagem do café diferem das do cacau, uma vez que o produto pode ser estocado em países de clima quente e seco. o fato de muitos países exportadores de café terem condições climäticas e instalações apropriadas para estocagem do produto, torna-os menos susceptíveis às im posições dos países consumidores. A possibilidade dos países exportadores de café de controlar a oferta mundial do produ to, coloca-os em melhores condições de negociações com os paí ses industrializados. A estocagem do café nos países exporta dores talvez seja um dos fatores que mais contribuem tanto pa ra a estabilidade dos preços como para a maior atuação dos Acordos Internacionais do Café.

Referente ao consumo de café, o Brasil è um grande consumidor. Nos ültimos anos verifica-se mudanças no consumo interno de café, havendo uma tendência de substituição do café tradicional (café em pó) pelo café solūvel. Na década de 70, o volume consumido de café solúvel era em média, de aproximadamente $9 \mathrm{mil}$ toneladas; no início da década de 80 , o consumo interno de café solüvel, alcançou cerca de $25 \mathrm{mil}$ toneladas (Tabela 18). O aumento significativo do consumo domés tico de café solüvel deve-se à melhoria da qualidade do produ to, facilidade de preparo e maior rendimento. Entretanto, ain da se mantem a predominância do consumo brasileiro de café, do tipo tradicional (café em pó). 
Tabela 18. Consumo Brasileiro de Café Cru em Grãos e Solúvel $1962-1981$

toneladas

\begin{tabular}{lccc}
\hline & Café Crü em & Café & \\
Período & Gräos & Solüvel & Total \\
\hline 1962 & 373.435 & - & 373.435 \\
1963 & 404.687 & - & 404.687 \\
1964 & 451.441 & - & 451.441 \\
1965 & 487.904 & 1.384 & 489.288 \\
1966 & 485.843 & 2.016 & 487.859 \\
1967 & 517.427 & 1.627 & 519.054 \\
1968 & 525.107 & 2.350 & 527.457 \\
1969 & 524.700 & 2.623 & 527.323 \\
1970 & 533.292 & 3.643 & 536.935 \\
1971 & 529.873 & 4.518 & 534.391 \\
1972 & 402.772 & 4.016 & 406.788 \\
1973 & 403.983 & 7.832 & 411.815 \\
1974 & 450.282 & 7.496 & 457.778 \\
1975 & 414.956 & 11.923 & 426.879 \\
1976 & 384.633 & 13.877 & 398.510 \\
1977 & 422.156 & 14.447 & 436.603 \\
1978 & 408.643 & 10.685 & 419.328 \\
1979 & 396.750 & 15.524 & 412.274 \\
1980 & 429.745 & 24.232 & 453.977 \\
1981 & 443.338 & 24.844 & 468.182 \\
& & & \\
\hline
\end{tabular}

Nota: Os dados foram transformados de sacas de $60 \mathrm{~kg}$ para toneladas

Fonte: Anuärio Estatístico do Café 1980/81 - MIC-IBC. 
0 elevado consumo interno de café é mais um dos fatores que favorece ao país negociar com os países desen volvidos, grandes consumidores do produto, face à garantia de colocação de uma parte significativa da produção no mercadoin ternacional, ao mesmo tempo que se contitue uma alternativapa ra redução da oferta do produto no mercado externo, refletindo positivamente no nivel de preços internacionais.

3.2.1. Grau de concentração das exportações brasileira de café cru em grãos

A tabela 19, apresenta o indice de Gini do va lor das exportações brasileira de café cru em grãos. obser va-se que o grau de concentração das exportações brasileirade café cru em grãos, apresenta-se mais estävel e sua tendênciaé de menor concentração, especialmente a partir dos anos 70 , quan do houve o incremento da industrialização do café,ocasionando o crescimento em ritmo acelerado das exportações de café solú vel. A política adotada no país, de diversificação na pauta das exportações brasileira,contribuiu para menor concentração das exportações de café cru em grãos. Outrossim, as exporta ções de café cru em grãos se destinam a um nümero maior de paises compradores tradicionais, resultando uma menor concen tração das exportações.

Outros fatores contribuiram para que as expor tações de café cru em grãos se apresentassem menos concentra das, a redução gradativa do consumo internacional de café, particularmente nos Estados Unidos, e a politica brasileira de redução das exportações de café cru em grãos, com o objeti vo de garantir preços remuneradores no mercado internacional. 
Tabela 19. Indice de Gini: Café Cru em Gräos (Valor das Ex portações Brasileira por Países Importadores). $1963-1982$

\begin{tabular}{llll} 
Periodo & Café & Periodo & Café \\
\hline 1963 & 0,63 & 1973 & 0,45 \\
1964 & 0,63 & 1974 & 0,47 \\
1965 & 0,61 & 1975 & 0,43 \\
1966 & 0,61 & 1976 & 0,49 \\
1967 & 0,61 & 1977 & 0,50 \\
1968 & 0,62 & 1978 & 0,49 \\
1969 & 0,55 & 1979 & 0,43 \\
1970 & 0,58 & 1980 & 0,48 \\
1971 & 0,57 & 1981 & 0,44 \\
1972 & 0,53 & 1982 & 0,48
\end{tabular}




\subsection{Mercado Internacional de Açücar.}

Entre os países produtores de açūcar de cana, Cuba e Brasil lideram a posição de maiores produtores mund ais seguidos da India, Austrālia, Filipinas e Africa do Sul. A produção de açúcarde cana representa aproximadamente $60 \%$ da produção mundial e de açúcar de beterraba cerca de $40 \%$.

No período analisado 1962/1963-1981 observa-se - crescimento acelerado da produção de açūcar no Brasil, In dia e República Dominicana, entre outros (Tabela 20). 0 incre mento da produção deveu-se em parte, ao rompimento das rela ções diplomáticas dos Estados Unidos com Cuba após a Revolu ção de Fidel Castro em 1959. A cota de exportação de Cuba pa ra o mercado norte-americano foi distribuida entre Brasil, Mé xico, República Dominicana e Peru, o que levou ao aumento da produção nesses países.

A produção brasileira, a partir de 1972 , repre senta aproximadamente $8 \%$ da produção mundial. A expansão ca navieira no Brasil foi favorecida pelo maior indice de mecani zação, notadamente nas regiões sudeste e sul do país. A moder nização teve como consequência o aumento da produtividade no setor canavieiro. No período 1962/1963-1981, a taxa anual mé dia de crescimento da produção brasileira de açücar foi de $5,51 \%$ (Tabela 21 ). Entre outros fatores que contribuiram para - incremento da produção de açúcar destaca-se: garantia pelo governo da colocação da safra; e financiamentos concedidos pe lo Banco do Brasil para qualquer valume de produção. Deve-se destacar também a divisão, em mercado livre e mercado preferencial norte-americano, onde os preços neste ültimo mercado, ao contrário do mercado livre, apresentavam-se elevados, in fluenciando maiores incrementos na produção. 


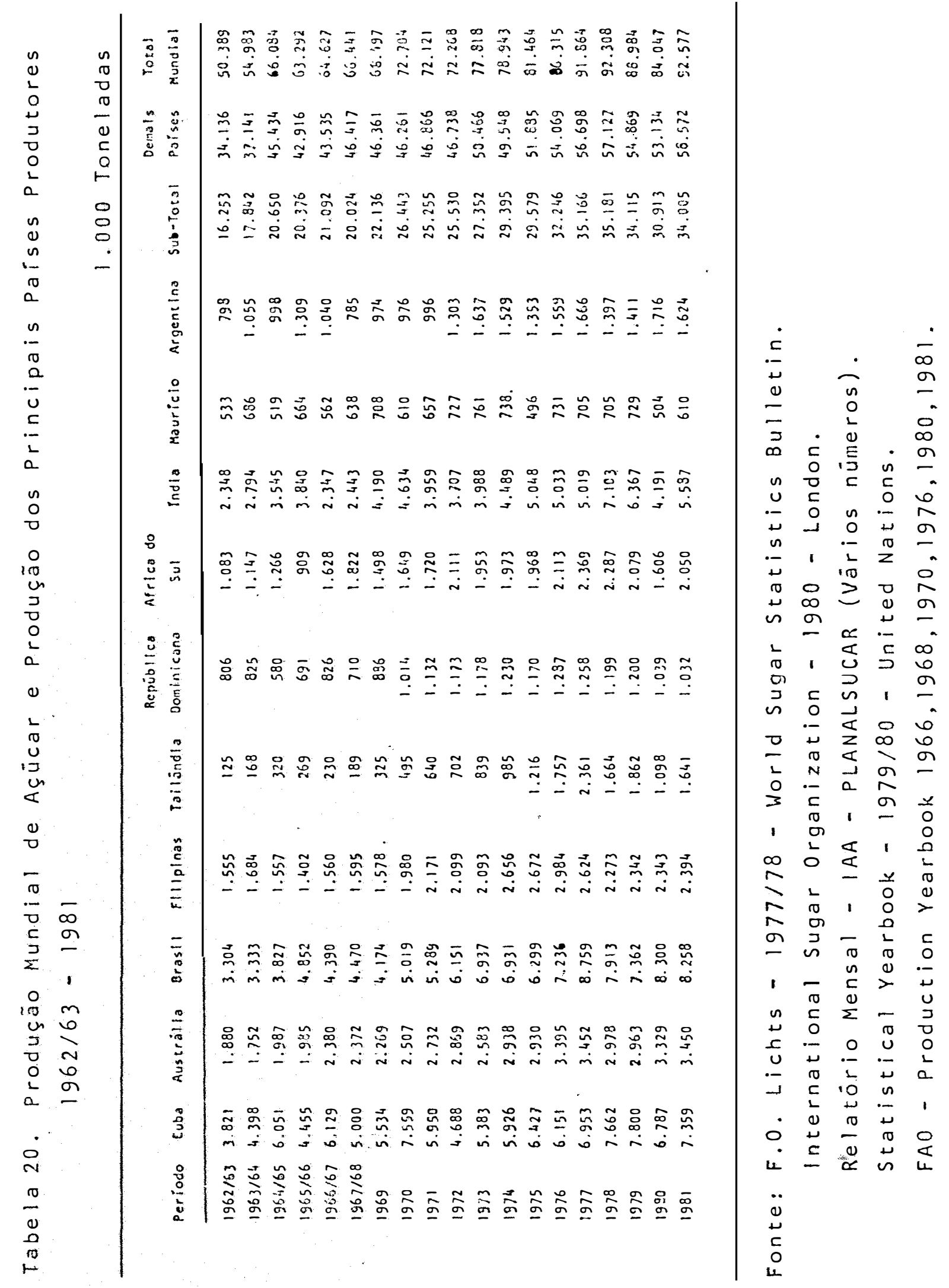


Tabela 21. Taxa Geométrica Anual Média de Crescimento nos Pe riodos 1962/63-1981, 1963-1982-Brasil

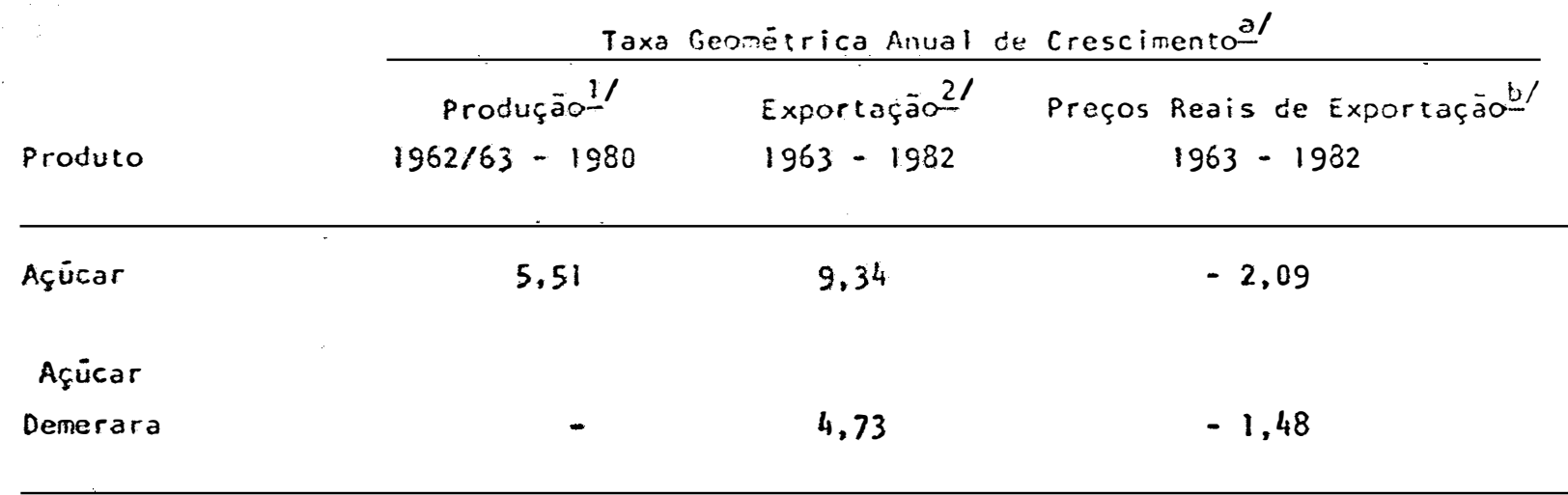

a/ Estimada atravēs do ajustamento da regressão linear simples onde a variāvel independente é a tendência e a variável de pendente é o logarítimo dos valores observados das variá veis. Determinado o coeficiente de regressão (b) a taxa geo mëtrica anual mëdia ( $r$ ) foí estimada atravēs da förmula $r=$ antilog $b-1$.

b/ Os preços fob das exportações brasileira de açūcar e de a çūcar demerara obteve-se dividindo o valor anual médio em dólar das exportações brasilleira de açücar e de açücar deme rara pelo volume em tonelada das exportações brasileira des tes produtos.

os preços em dólar por tonelada foram deflacionados pelo ín dice de preço no atacado dos Estados Unidos corrigidos,base $1982=100$.

Fonte:

1/ Relatörio Mensal - IAA - PLANALSUCAR (Vārios nümeros). FAO - Production Yearbook 1966,1968,1970,1976,1980,1981

2/ MIC-IAA Departamento de Exportação. Comércio Exterior Brasil - Banco do Brasil - CACEX. 
Dentre os principais paises exportadores de açucar de cana estão Cuba, Brasil. Austrälia e Filipinas (Ta bela 22). A participação do Brasil na exportação mundial de. açücar no período 1963-1971 era em média 4\%. A partirde 1971, a participação do Brasil aumentou, alcançando em 1972 e 1973 $11,90 \%$ e $12,82 \%$ respectivamente. Outros países como Austrá lia, Filipinas, Cuba e Repüblica Dominicana aumentaram sua participação na exportação mundial de açūcar, notadamente no período 1970-1975. O aumento da participação desses países na exportação mundial de açücar, foi resultante do desequilíbrio entre demanda e oferta, sendo a demanda continuamente supe rior à oferta, alèm da ocorrência de frustrações de safra em al uns paises produtores.

A taxa média anual de crescimento das exporta çós brasileira de açúcar, no período $1963-1982$, foi de $9,34 \%$ enquanto que a taxa média de crescimento das exportações de açücar demerara foi de $4,73 \%$ ao ano (Tabela 21 ). 0 aumento das exportações brasileira de açūcar deve-se ao crescimento do consumo mundial, notadamente nos paises em desenvolvimento, num periodo em que poucos países produtores puderam atender o aumento da demanda mundial. O Brasil aproveitando a oportunidade, colocou no mercado internacional desde 1970, volumes sig nificativos de açúcar, chegando a exportar em 1973 cerca de 3 millões de toneladas. A partir deste ano ficou evidenciado a potencialidade do açúcar brasileiro no mercado internacional.

Observa-se pelos dados da Tabela 23 , que no pe riodo 1963-1970, o Brasil exportou um único tipo de açücar, o denominado açúcar demerara. A participação do açúcar demerara no volume das exportações brasileira de açúcar vem decrescenlo dasde 1971, atingindo 43,83\% em 1982. Esta modificaça nas exportações trasileira de açúcar deve-se à diversificação na pauta das exportações brasileira e a intensificação da 


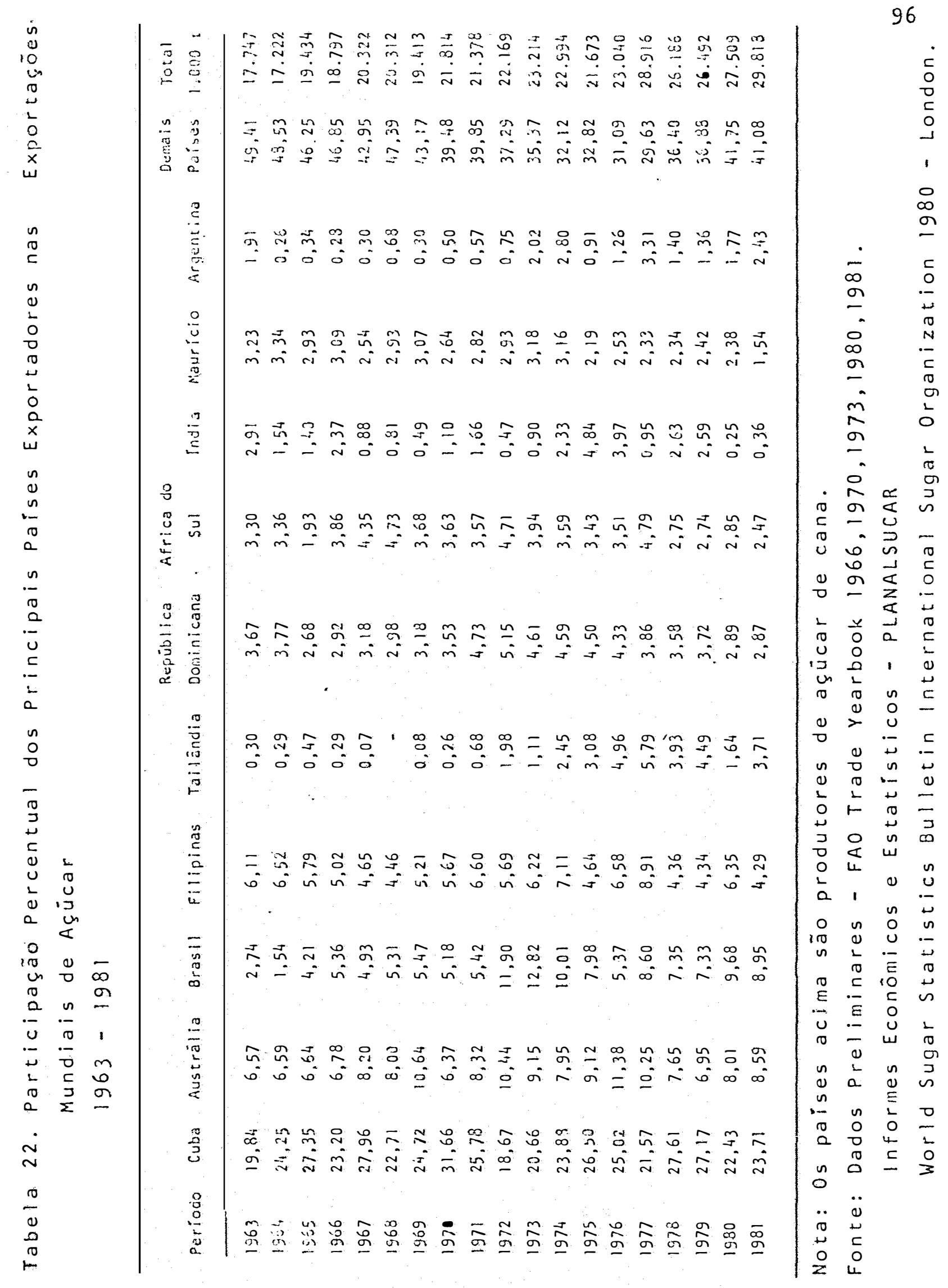


Tabela 23. Exportação Brasileira de Açúcar, Açücar Demerara e Participaçäo Percentual $1963-1982$

1.000 Toneladas

Açūcar Relação Demerara na

Período Açücar Demerara Exportação Total de Açūcar

\begin{tabular}{lrrl}
\hline 1963 & 487 & 487 & 100,00 \\
1964 & 266 & 266 & 100,00 \\
1965 & 818 & 818 & 100,00 \\
1966 & 1.007 & 1.007 & 100,00 \\
1967 & 1.001 & 1.001 & 100,00 \\
1968 & 1.079 & 1.079 & 100,00 \\
1969 & 1.061 & 1.061 & 100,00 \\
1970 & 1.130 & 1.130 & 100,00 \\
1971 & 1.159 & 1.158 & 99,91 \\
1972 & 2.638 & 2.054 & 77,86 \\
1973 & 2.977 & 2.354 & 79,07 \\
1974 & 2.302 & 1.767 & 76,76 \\
1975 & 1.730 & 1.235 & 71,39 \\
1976 & 1.238 & 601 & 48,55 \\
1977 & 2.487 & 1.536 & 61,76 \\
1978 & 1.925 & 1.164 & 60,47 \\
1979 & 1.942 & 1.283 & 66,07 \\
1980 & 2.662 & 1.392 & 52,29 \\
1981 & 2.670 & 1.564 & 58,58 \\
1982 & 2.788 & 1.222 & 43,83 \\
& & & \\
\hline
\end{tabular}

Nota: Os tipos de açúcar exportados estão convertidos em va lor demerara.

Fonte: Dados Preliminares - MIC - IAA Departamento de Expor tação (Dados 1963 - 1971).

Comércio Exterior Brasil - Banco do Brasil - CACEX (Dados 1972 - 1982). 
industrializaça no país, a partir da dëcada de 70. Assim, os açúcares cristal e refinado vêm conquistando a cada ano, maior participação nas exportações brasileira de açúcar.

A receita brasileira com as exportações de açú car cresceram num ritmo acelerado de 1963 a 1974 , com exceção do ano de 1964, quando as exportações reduziram-se, em termos de volume e valor praticamente a metade, se compara das ao ano anterior (Tabela 24). 0 valor da receita cambial das exportações de açúcar atingiu o recorde de 1,33 bilhão de dólares em 1974, devido ao significativo aumento dos preços neste periodo. A participação das exportações de açúcar no va lor das exportações brasileira em 1974, foi de $16,74 \%$, superando neste ano a participação do café. Conforme citado anteriormente, o Brasil soube aproveitar na época as condições fa voráveis do mercado internacional de açúcar. O crescimento ace lerado da demanda e a redução das safras de alguns grandes pro dutores, favoreceu o Brasil e outros paises produtores.

A redução na oferta, consequentemente ocasio nou aumentos substanciais no preço do produto, o que incenti vou altos investimentos na atividade canavieira. 0 consequen te aumento da produçãom mundial de açücar, refletiu no desequi librio entre oferta e demanda acompanhado de queda de preços no mercado internacional. A receita de exportação brasileira de açúcar reduziu-se drasticamente a partir de 1976, sendoque a participação das exportações de açúcar no valor das. exporta ções brasileira reduziu-se a $3,06 \%$, recuperando-se apenas em 1980 , quando atingiu $6,32 \%$.

Entre os principais países importadores de açú car, destacam-se Estados Unidos, União Soviética, os países pertencentes à Comunidade Econômica Européia e Japão. No pe riodo 1963-1981, verifica-se uma tendência de queda nas 


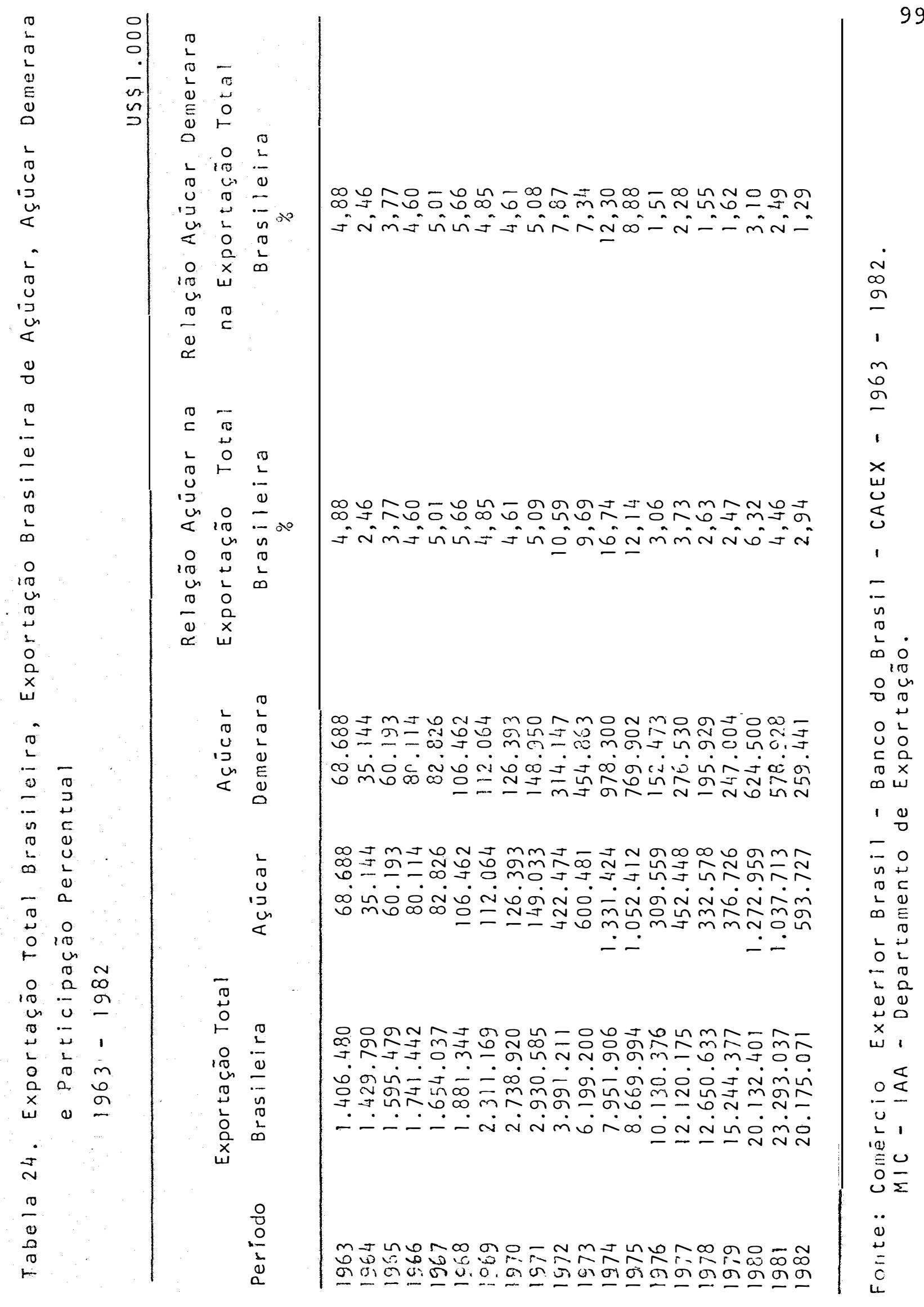


importações de açücar pela CEE, (Tabela 25). A participação das importações de açūcar da CEE nas importações mundiais,que em 1963 era de 24,29\%, passou nos anos 1979-1981 para menos de $10 \%$. Esta redução deve-se a politica de subsidios da CEE, incentivando o aumento da produção de açūcar de beterraba. 0 aumento significativo da produçãode açūcar de beterraba fez com que a CEE, passasse de grande importadora do produto para segundo maior exportador mundial de açúcar.

Por outro lado, a participação dos Estados Uni dos e Japão nas importações mundiais de açūcar vem decrescen do devido à política adotada por esses países de expansão do uso de sucedâneos, ou seja, o uso dos adoçantes de milho o "High. Fructose Corn Syrup" (HFCS). 0 uso de sucedâneos deverá ter continuidade nos Estados Unidos e Japão, considerando que o produto vem conquistando parte substancial do mercado, em consequência da politica protecionista de menores preços dos sucedâneos.

Assim, como o café e cacau, o açucar também se caracteriza por ciclos de preços. A situação de excassez do produto e alta de preços em 1962-1963 incentivouos paises pro dutores a investirem maciçamente na atividade canavieira. os elevados investimentos ocasionaram o aumento significativo da produção mundial de açūcar, gerando uma situação de super pro dução. Observa-se na Tabela 26, o declínio dos preços das ex portações brasileira de açúcar em 1964-1965. A sūbita recuperação dos preços ocorreu a partir de 1974, quando o preço das exportações brasileira de açūcar atingiu US\$ 578 por tonelada. os elevados niveis de preços no mercado internacional a par tir de 1974, devem-se ao aumento do consumo no período de ba xa dos preços e ao desestimulo dos paises produtores a investirem no aumento da produção, quando as cotações vigentes na época sequer cobriam os custos de produção. 
Tabela 25. Participação Percentual dos Principais Países Im portadores nas Importações Mundiais de Açúcar $1963-1981$

\begin{tabular}{|c|c|c|c|c|c|c|c|c|c|c|}
\hline & Estadus & & & & & & & & Letsij & TC:Bi \\
\hline Feriodo & linicos & LiRSS & Jup & C.E.E. & Cnino & Conata & Argilia & Suir-ic:i i & $P=i$ ses & $\begin{array}{r}n a r i c 1 \\
1.001 \\
\end{array}$ \\
\hline $1 \leq \leqslant 3$ & 23.43 & 6.50 & 2.37 & 24,20 & 2,54 & 4.35 & $\therefore, 2 \hat{c}$ & $7: .2 \%$ & 20.73 & $77.30 j$ \\
\hline 1904 & 19.35 & 11.04 & 5,03 & 23.17 & 2.35 & 4,20 & 1.25 & $7 \pi, 49$ & $29.5 !$ & $16.5: 7$ \\
\hline 1505 & 12.77 & 12.53 & 9.10 & $\{\varepsilon . \varepsilon\rangle$ & 2,14 & 4.55 & $1 .: 0$ & 67.34 & $32, E t$ & 18.634 \\
\hline 1905 & 20.02 & $g, 62$ & 8.55 & 18.65 & 3.23 & 4.12 & 1,11 & $6.5,73$ & 34.27 & 19.173 \\
\hline $15 \vdots 7$ & 21,25 & 12,32 & 8.94 & 17.40 & 2,75 & 4,45 & 1,55 & 62.73 & 31,27 & $2 c . i \Sigma \varepsilon$ \\
\hline 1568 & 23.12 & 8.50 & 9.23 & 17.16 & 2.21 & $\therefore, \therefore 5$ & 1.34 & ef.is & 33.51 & 15.548 \\
\hline 1969 & 22.72 & 7.02 & 10,45 & 17.05 & 2,34 & 5,03 & 0.56 & EE, 62 & 33.95 & 19.521 \\
\hline 1570 & $21.5 i$ & 13.50 & 10.09 & 15.30 & 2.59 & $4,3:$ & 0.98 & 68.77 & 31,23 & 22.133 \\
\hline 1971 & 22.92 & 3.28 & 10,72 & 15.96 & 2,13 & 4.25 & 1,12 & 64.33 & 35.67 & 21.153 \\
\hline 1972 & 21,86 & 0.83 & $12,2 i$ & 16,15 & 3.45 & 4,18 & 1.06 & $67,8.2$ & 32,18 & $21.71 \varepsilon$ \\
\hline 1973 & 20.65 & 11,47 & 10.31 & $H_{1}, 6$ & 3.20 & 4,19 & 0,31 & 65.37 & $34.2 \vdots$ & 22.573 \\
\hline 1974 & 23.05 & 8,25 & 12.16 & 12.20 & $1,5 i$ & 3.96 & 1,22 & $\epsilon: 67$ & $3 ! .3 !$ & 22.714 \\
\hline $19 ? 5$ & 15,70 & 14.57 & 11.25 & $\{e, ?\}$ & $1, i=1$ & $\therefore .40$ & 2.10 & 60,03 & 31.97 & $22.2-2$ \\
\hline 1975 & 18,24 & 16.57 & 10.72 & $14,: 0$ & 2,76 & 4.00 & 1.58 & 67.55 & 32.05 & 22.653 \\
\hline 1577 & 15.27 & $i 7,35$ & 5.79 & 11,27 & 6.05 & 3.85 & 1,50 & 60,16 & $3: .81$ & 27.522 \\
\hline 1978 & $14.9 i$ & 15,65 & $\varepsilon, 94$ & 10.34 & $5.6 i$ & 4,25 & 1,71 & $6: .25$ & $35,-25$ & 25.502 \\
\hline 1579 & 16,57 & 15.79 & 10.05 & 9.57 & $2 ., 2 i$ & 3.93 & 1,58 & 62.54 & 37.06 & $2 \equiv . \equiv 65$ \\
\hline $\operatorname{sis} 0$ & $\{j, i i$ & 18.33 & 8,31 & 8,45 & 3.53 & 3.22 & 2,15 & 57.31 & 42.29 & $27.2::$ \\
\hline 1981 & 15.87 & 18,02 & 5.43 & 7.09 & 3.89 & 2,59 & $2,1:$ & 55,16 & 44,54 & 28.697 \\
\hline
\end{tabular}

Nota: Os tipos de açūcar importado estão convertidos em va lor demerara.

Fonte: FAO - Trade Yearbook - 1966,1970,1973,1976,1977,1978, $1979,1980,1981$. 
Tabela 26. Preços Médios das Exportaçōes de Açucár e de Açü car Demerara.

$1963-1982$

$U S \$ / t$

Açūcar

\begin{tabular}{|c|c|c|}
\hline Período & $A c ̧ \bar{u} c a r$ & Demerara \\
\hline 1963 & 141 & 141 \\
\hline 1964 & 132 & 132 \\
\hline 1965 & 74 & 74 \\
\hline 1966 & 80 & 80 \\
\hline 1967 & 83 & 83 \\
\hline 1968 & 99 & 99 \\
\hline 1969 & 106 & 106 \\
\hline 1970 & 112 & 112 \\
\hline 1971 & 129 & 129 \\
\hline 1972 & 160 & 153 \\
\hline 1973 & 202 & 193 \\
\hline 1974 & 578 & 554 \\
\hline 1975 & 608 & 6.23 \\
\hline 1976 & 250 & 254 \\
\hline 1977 & 182 & 180 \\
\hline 1978 & 173 & 168 \\
\hline 1979 & 194 & 193 \\
\hline 1980 & 478 & 449 \\
\hline 1981 & 389 & 370 \\
\hline 1982 & 213 & 212 \\
\hline
\end{tabular}

Fonte: Dados Preliminares - MIC - IAA - Departamento de Ex portação (Dados 1963 - 1971).

Comércio Exterior Brasil - Banco do Brasil - CACEX (Dados 1972 - 1982). 
A situação de déficit na oferta mundial de açü car, no período de 1973-1975, levou a redução dos estoques. Ob serva-se na Tabela 27 , que a relação estoque/consumo passou de $21,48 \%$ em 1972/1973 para 20,42\% em 1973/1974, quando a rela ção ideal para o açúcar seria de aproximadamente $28 \%$, a qual proporcionaria melhor segurança ao mercado.

A partir de 1976, os preços novamente declina ram devido ao crescimento da produção a nivel superior ao do consumo. Entre os fatores que contribuiram para o aumento sig nificativo da produção mundial de açúcar, destaca-se a expansão da àrea plantada, incentivada pelos subsídios governamentais em diversos países produtores.

Em 1979 ocorre novamente a elevação do consumo, influenciado pelos baixos preços vigentes e também por campa nhas de expansão do consumo na India e China. Por outro lado, os paises exportadores de petróleo aumentaram significativamen te o consumo de açúcar branco. Mas neste mesmo ano, ocorreure dução na produção mundial de açúcar, atribuida a frustração das safras na União Soviētica, Cuba, Täilândia, Tndia e Peru ocasionando a elevação dos preços.

A recuperação das safras mundiais a partir de $1980 / 1981$ em especial a de Cuba, que conseguiu combater a fer rugem nos canaviais, e a recuperação das safras da india, Tai lấndia e Âfrica do Sul, levou novamente à brusca quedanos pré ços. Contribuiu também para o declínio dos preços do açūcar no mercado internacional, as altas taxas de juros que fez com que os paises importadores reduzissem o nivel de seus estoques, em consequência dos elevados custos financeiros.

A taxa negativa de crescimento médio anual dos preços de todos os tipos de açūcar $(-2,09 \%)$ e de açúcar demerara 


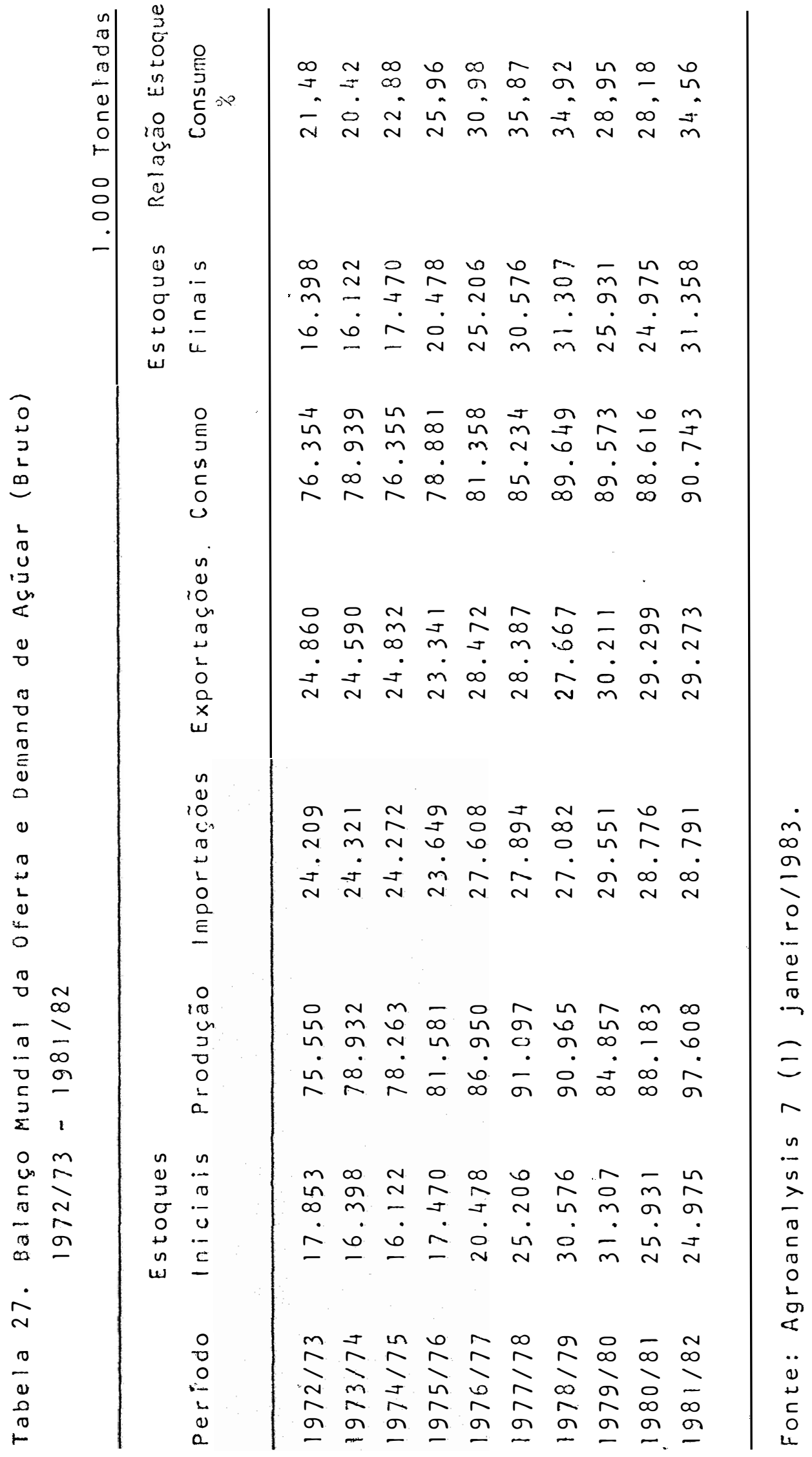


$(-1,48 \%)$, no período de $1963-1982$, deve-se ao aumento signi ficativo da produção brasileira e mundial.

No Brasil, a confiança no Programa Nacional do Alcool-proälcool, implementado em 1975 como uma fonte alterna tiva de combustivel face a crise energética mundial, levou o país a investir maciçamente na agroindústria açucareira. A no va opção de utilização de cana-de-açúcar como matéria prima para a produção de álcool combustível, ao reduzir a oferta de açūcar no mercado internacional favorece o Brasil, uma vez que poderá contribuir para a estabilidade de preços do açūcar no mercado externo.

Com relação a estocagem do açúcar, tanto paí ses produtores como consumidores estocam o produto. Alguns pa ses como o Brasil possuem condições apropriadas para a estoca gem do produto. o problema mais gravoso atualmente no mercado internacional do açúcar é a grande expansão da produção de açúcar de beterraba. Esta cultura se caracteriza por ciclo curto de produção, enquanto que a cultura de cana-de-açúcar é de ciclo médio, aproximadamente 18 meses. 0 descompasso dos paises produtores de açúcar de beterraba e de cana na coloca ção das safras mundiais, tem levado a frequentes desequilibri os no mercado internacional de açúcar, contribuindo para maior instabilidade dos preços.

Nos últimos anos, a procura de auto-suficiência na produção de açúcar pelos países produtores de açūcar de be terraba, em sua maioria países desenvolvidos, tem tornado vul neráveis os países produtores de açücar-de-cana, os quais em sua maioria, caracterizam por estarem em fase de desenvolvi mento e altamente dependentes das exportações de produtos pri mários. Conforme, citado anteriormente, a polftica protecionis ta norte-americana e japonesa, no tocante ao uso de sucedá 
neos do açúcar, tem agravado ainda mais a situação dos países produtores de açūcar de cana. Ressalta-se também, o protecionismo da CEE aos países produtores de açúcar de beterraba.

o consumo brasileiro de açúcar é elevado, pelos dados da Tabela 28 , pode-se constatar que o consumo interno de açūcar vem gradativamente aumentando. A participação do consumo interno na produção brasileira de açúcar, representa mais de $50 \%$. Entre os fatores que contribuiram para o aumento significativo do consumo brasileiro de açúcar, destaca-se a campanha elaborada pela Cooperativa Central dos Produtores de Açúcar e Álcool do Estado de São Paulo-Coopersucar, enfatizan do o valor nutritivo do açücar-de-cana, quando comparado aos adoçantes artificiais.

O elevado consumo interno de açúcar assim, co mo a opcão brasileira atravēs do Proālcool, coloca o Brasil frente aos países participantes das negociações para implemen tação do Acordo Internacional do Açūcar em condições mais fa voráveis, face a garantia de colocação de parte substancial do produto no mercado interno.

3.3.1. Grau de concentraçãodas exportações brasileira de açūcar demerara

o indice de Gini do valor das exportações bra sileira de açúcar demerara quando comparado com o de cacau em amendoas e café cru em grãos apresenta-se mais concentrado.Tal resultado pode ser atribuido ao fato, das exportações brasileira de açúcar demerara no período 1963-1982, terem se desti nado a um numero reduzido de principais países compradores. 
Tabela 28. Produção e Consumo Brasileiro de Açúcar e Parti cipação Percentual

$1963-1979$

1.000 Toneladas

\begin{tabular}{|c|c|c|c|}
\hline & & & Relaçāo Consumo \\
\hline Período & Produção & Consumo & $\underset{\%}{\operatorname{Produção~}}$ \\
\hline 1963 & 3.304 al & 2.764 & 83,66 \\
\hline 1964 & 3.333 al & 2.672 & 80,17 \\
\hline 1965 & $3.827^{a /}$ & 2.979 & 77,84 \\
\hline 1966 & 4.852 I/ & 2.763 & 56,95 \\
\hline 1967 & 4.390 al & 2.929 & 66,72 \\
\hline 1968 & 4.470 a & 3.319 & 74,25 \\
\hline 1969 & 4.174 & 3.401 & 81,48 \\
\hline 1970 & 5.019 & 3.495 & 69,64 \\
\hline 1971 & 5.298 & 3.576 & 67,50 \\
\hline 1972 & 6.151 & 3.816 & 62,04 \\
\hline 1973 & 6.937 & 4.092 & 58,99 \\
\hline 1974 & 6.931 & 4.777 & 68,92 \\
\hline 1975 & 6.299 & 4.990 & 79,22 \\
\hline 1976 & 7.236 & 5.091 & 70,36 \\
\hline 1977 & 8.759 & 5.060 & 57.77 \\
\hline 1978 & 7.913 & 5.289 & 66,84 \\
\hline 1979 & 7.362 & 6.009 & 81,62 \\
\hline
\end{tabular}

al Corresponde ao ano safra 1962/63 - 1967/68.

Fonte: FAO - Production Yearbook 1966,1968,1970,1976,1980.

Statistical Yearbook 1979/80 - United Nations.

F.0. Lichts - 1977/78 - World Sugar Statistics Bulle tin.

International Sugar Organization - 1980 London.

Relatōrio Mensal - IAA - Planalsucar (Vários Números). 
Tabela 29. Indice de Gini: Açūcar Demerara (Valor das Ex. portações Brasileira por Países (mportadores). $1963-1982$

\begin{tabular}{llll}
\hline Periodo & Açücar & Periodo & Açücar \\
\hline 1963 & 0,87 & 1973 & 0,51 \\
1964 & 0,80 & 1974 & 0,59 \\
1965 & 0,73 & 1975 & 0,39 \\
1966 & 0,79 & 1976 & 0,55 \\
1967 & 0,82 & 1977 & 0,54 \\
1968 & 0,80 & 1978 & 0,66 \\
1969 & 0,85 & 1979 & 0,82 \\
1970 & 0,82 & 1980 & 0,73 \\
1971 & 0,80 & 1981 & 0,77 \\
1972 & 0,66 & 1982 & 0,71 \\
& & & \\
\hline
\end{tabular}


exportações apresentam-se menos concentradas, atingindo o in dice de 0,39 em 1975. Este indice, é resultante da queda das exportações de açúcar demerara, para os grandes países importadores particularmente no período 1974-1976, quando os pre ços do produto no mercado internacional alcançaram niveis bas tante elevados. Por outro lado, a politica de industrializa ção brasileira contribuiu para expansão das exportações de ou tros tipos de açúcar, como o cristal e refinado.

Nos ültimos quatro anos foi maior o indice de concentração das exportações brasileira de açūcar demerara. observa-se a não importação nestes anos por parte do chile, (exceto 1980), China (exceto 1982), França (exceto 1979), Ja pão (exceto 1982) e Reino Unido (Tabela 30). A não importação pelo Chile é atribuida ao desenvolvimento da indústria chilena de açücar de beterraba a partir de 1960. A produção doméstica passou a atender um terço das necessidades do país. 0 crescimento da indústria doméstica, resultou dos esforços da Organização Estadual do Açūcar, a qual instalou fábricas para reduzir a dependência das importações.

A não exportação de açúcar demerara neste perío do para China deve-se ao programa nacional chinês de aumento da produção de açúcar a partir de 1976, com objetivo de aten der a crescente demanda. A expansão da produção de açūcar de cana na China é atribuída a uma série de incentivos, entre eles: elevados preços pagos pelo Estado, maiores dotações de outros gêneros alimentícios aos agricultores que ultrapassem as metas de produção de cana e financiamentos de projetos hi dráulicos relacionados com as plantações de cana-de-açúcar. No caso da França e Reino Unido, a não importação deve-se à expansão da produção de açúcar de beterraba, incentivada pela politica protecionista da CEE e, com relação ao Japão, à poli tica de incentivo ao uso do sucedàneo "HFCS". Assim, as 


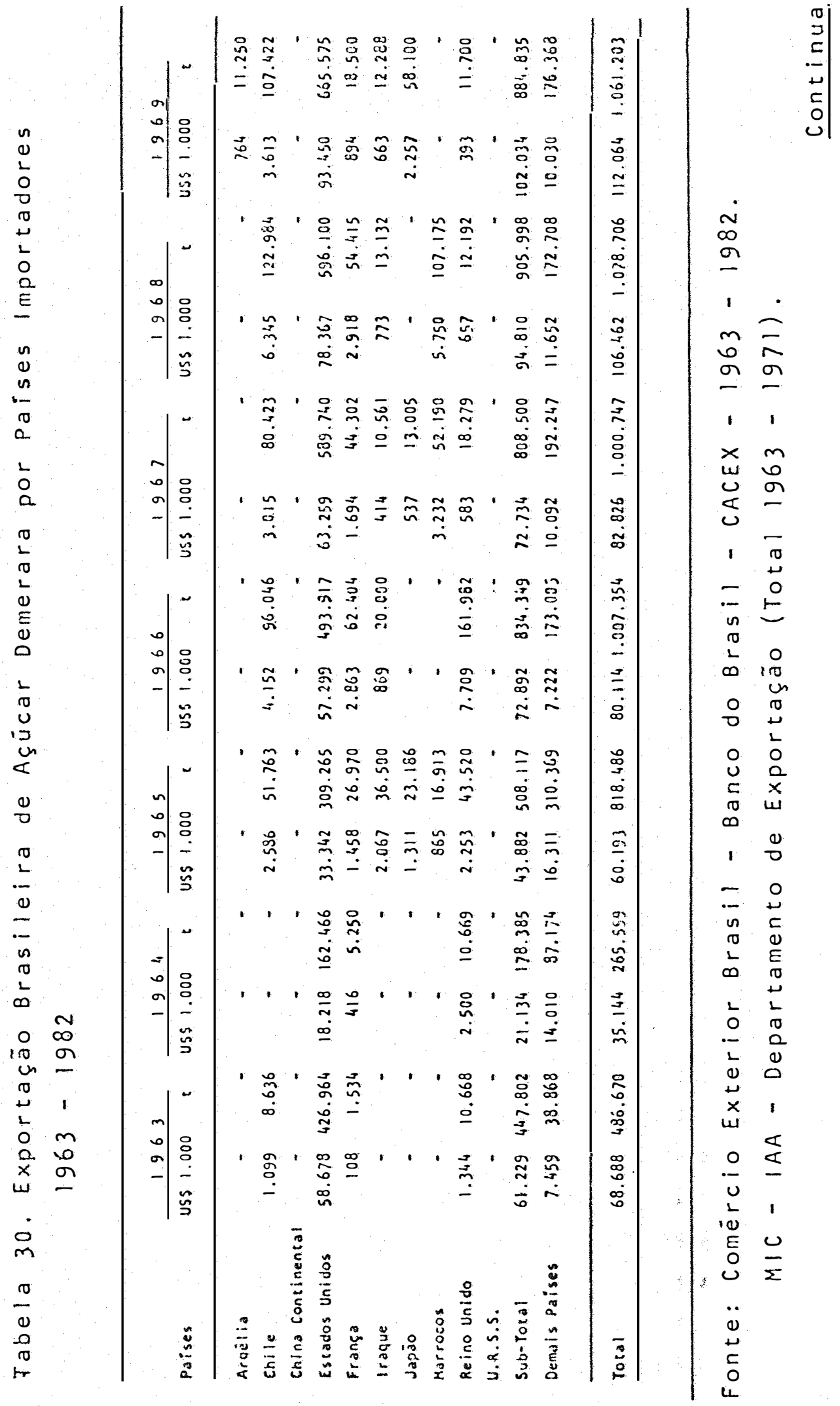




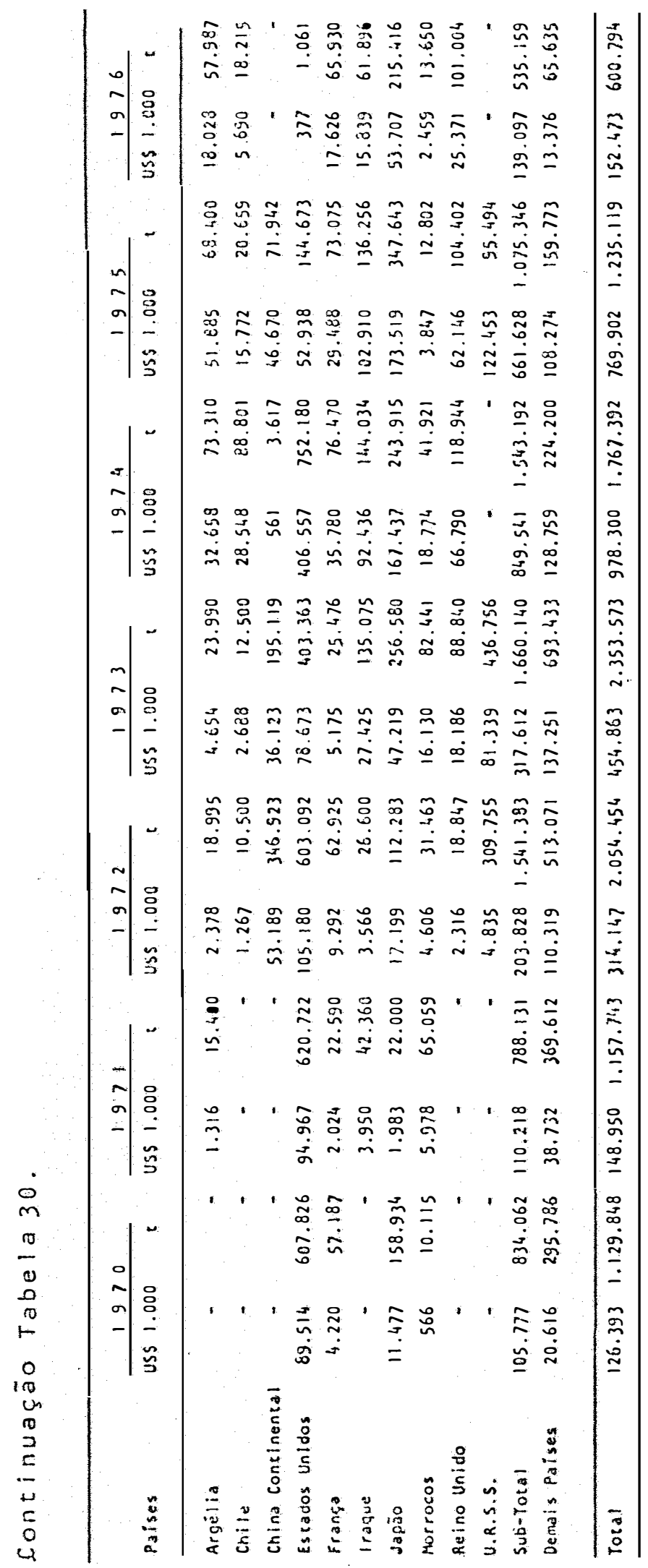




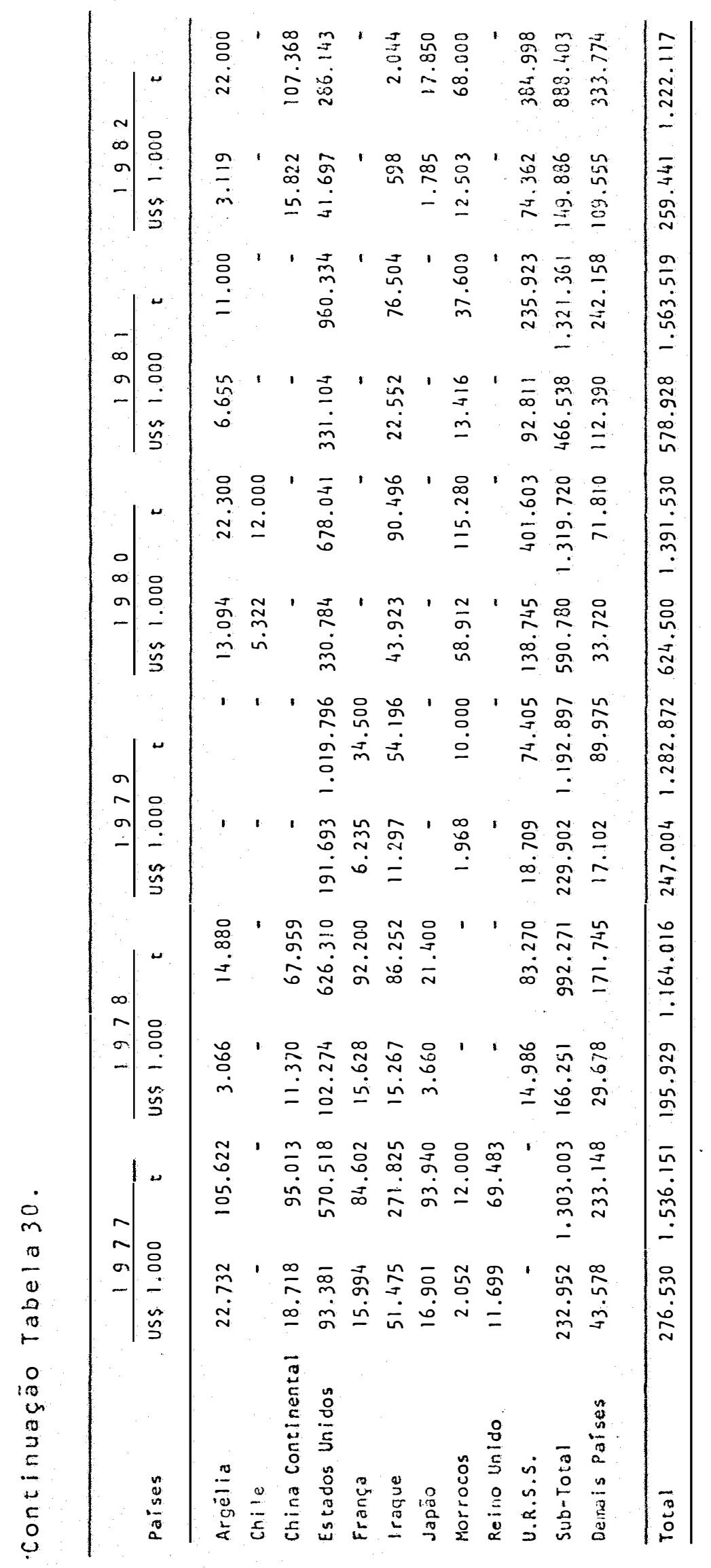


exportações para um menor número de tradicionais países impor tadores, ocasionaram maior concentração das exportações brasileira de açücar demerara. 
4. CONCLUSÕES

0 mercado internacional de "commodities" carac teriza-se pelas frequentes flutuações de preços.

A instabilidade de preço das "commodities" no mercado internacional levaram paises produtores e consumido res a negociarem a implementação de Acordos Internacionais, com o objetivo de estabilizar os preços.

o objetivo deste estudo é apresentar um quadro analitico das negociações para implementação dos Acordos In ternacionais de Cacau, Café e Açūcar e do comportamento do mercado internacional destes produtos, enfatizando as dificul dades de negociações e os efeitos dos respectivos acordos.

As oscilações entre oferta e demanda se con tituem a principal causa da instabilidade de preços destes produtos. No entanto, a alta concentráção tanto do lado da oferta, como da demanda, poderia favorecer os entendimentos entre paises produtores e consumidores na busca de uma politi ca conjunta para estabilização dos preços.

Verifica-se que as negociações entre países pro 
dutores e consumidores de cacau, café e açücar para implementação de Acordos Internacionais com seus mecanismos de estabi lização de preços, se constituem em constantes debates. Por outro lado, as características distintas entre os países nego ciadores, de um lado, países desenvolvidos e do outro paises em desenvolvimento, levam a maior dificuldade de consenso. Um dos aspectos relevantes para um melhor nivel das negociacoós de Acordos Internacionais seria a formação de um grupo coeso de paises produtores/exportadores para que diante dos consumi dores, suas reivindicaçoes superem os interesses nacionaiseconômicos e políticos dos países consumidores.

No relativo a cacau, a Aliança dos Países Pro dutores de Cacau, tem como um dos objetivos a busca de maior integracão entre os países produtores. Apesar de que os esfor ços da Aliança na busca da estabilização de preços do prodú to, venham sendo limitados, a simples existência desta organi zação, predispõe maior credibilidade por parte dos países con sumidores.

No tocante ao café, verificou-se que a formação de um grupo coeso de países produtores quer através do co mitê de Coordenação ou do Grupo de Bogotá, muito contribuiu para a sustentação das cotações no mercado internacional.

A maior integração entre os países produtores aumentaria o poder de barganha diante dos consumidores e leva ria a uma maior participação dos mesmos, no comércio interna cional do produto.

De modo geral, os mecanismos de estabilização de preços, faixa de preços - máximo e mínimo, cota de expor tação e estoque regulador, utilizados nos Acordos de cacau, café e açūcar não têm surtido o efeito esperado, ou seja, de 
estabilização de preços, notadamente no caso do cacau e açú car.

Na anālise do mercado internacional dos t.rês produtos (Capitulo 03), verifica-se que os desequilibrios en tre oferta e demanda têm anulado os esforços dos países produ tores e consumidores na busca de estabilização do mercado in ternacional destas "commodities". No que diz respeito ao ca cau, os Acordos de 1972 e de 1975 não entraram em operação, uma vez, que os preços no mercado internacional permaneceram acima, das faixas de preços estabelecidas nos respectivos Acor dos, dada a excassez de oferta do produto. Outrossim, durante as negociações para implementação do Acordo Internacional de Cacau de 1980, o não entendimento imediato, entre os países participantes e a condição que se apresentava de excedentes de produção, ocasionou a brusca queda dos preços no mercado in ternacional. Um outro aspecto, que tem a influência sobre a não efetividade dos Acordos, são as características dos prin cipais paises produtores, em sua maioria ex-colonia dos pá ses consumidores e altamente dependentes da receita de expor tação de cacau, o que os impossibilita de conter a expansão da produção do produto. Destaca-se tambëm, o incentivo a pro dução de sucedâneos da manteiga de cacau, que nos últimos anos tem aumentado significativamente.

Com relação ao mercado açucareiro, as cond $\underline{\mathbf{i}}$ çöes de mercado, ou seja, os frequentes desequilibrios entre a oferta e demanda de açücar no mercado internacional, tem prejudicado a atuação dos Acordos. Tal situação se agravou, a partir da expansão da produção de açūcar de beterraba nos paí ses desenvolvidos, prejudicando os produtores de açúcar de cana, em sua maioria paises em desenvolvimento. Um outro fa tor que vem contribuindo para não efetividade dos Acordos são os incentivos dos grandes países consumidores como os Estados 
Unidos e Japão, a produção do substituto do açücar o "HFCs".

De modo geral, tem sido efetivo o Acordo In ternacional de. Café. Com seus mecanismos de estabilização, no tadamente o de cota de exportação, vem sendo possível manter os preços do produto relativamente estáveis, o que pode ser atribuído a politica de comercialização e estocagem do produ to, assim, como o maior entrosamento entre os grandes países produtores e a menor concentração da produção em termos geográficos.

- Brasil ocupando as primeiras colocações co mo produtor e participando significativamente das exportações mundiais de cacau, café e açūcar, possui determinadas condi ções que o coloca em melhor posição nas negociações dos Acor dos Internacionais destes produtos.

O elevado crescimento da industrialização de cacau a partir da década de 70 abriu perspectiva para o apri moramento das condições de estocagem do produto na forma de derivados, por um período de tempo mais longo. Por outro lado, as campanhas para expansão do consumo brasileiro do produto final chocolate, tem logrado bons resultados, o que possibili tará ao país no futuro pröximo, negociar em melhor nível com os países consumidores, além de contar com mais uma alternati va para a estabilização de preços do produto, no mercado ex t.erno.

A posição do Brasil frente aos paises partici pantes das negociações do Acordo Internacional de Café, apresenta-se bastante favorävel, o país conta com um eficiente sis tema de estocagem sendo ainda, grande consumidor do produto.

Com relação ao açücar, o Brasil possuí adequạ 
do sistema de estocagem e consumo interno elevado. Destaca-se também, o Programa Nacional do Alcool-PROALCOOL instituído com o objetivo de economizar divisas estrangeiras diante da crise energētica. A utilizaçäo da matēria prima na produção do ālco ol combustível, é mais uma opção que favorece ao país, junto aos negociadores do Acordo Internacional do Açücar, ao tempo que se constitue alternativa para retirada de parte do exce dente de produção do mercado externo.

A exemplo da comercialização do café este estü do sugere que gradativamente seja ampliada a capacidade de es tocagem nos países produtores para que estes se tornem menos vulneráveis às manobras especulativas dos paises consumidores.

Apesar de que a politica adotada pelo Governo brasileiro de expansão das exportações, venha obtendo resulta dos favoräveis, verifica-se o alto grau de concentração das expor tações brasileira de cacau em amêndoas, café cru em grãos e açücar. demerara. Não obstante, a partir dos anos 70 , as políticas adota das de intensificação da industrialização e diversificação na pauta das exportações brasileira tenha reduzido o grau de concen tração das exportações, o Brasil deveria adotar uma politica mais agressiva de conquista de novos mercados para melhorse posi cionar frente aos países participantes das negociações dos $\underline{A}$ cordos e consequentemente gerar superävits comerciais crescentes.

Embora, a efetividade dos Acordos seja de cur to prazo, a existência dos mesmos. é de suma importância, pois, ao mesmo tempo, que constituem o respaldo politico dos paises produtores/exportadores, é o elemento "psicológico" de estabi lizaçäo de preços. Destaca-se ainda que qualquer dos mecanismos adotados nos Acordos, objetivando estabilizar preços, de vem vir açompanhados de politicas adequadas de comercialização e estocagem para viabilidade do pacto. 
LITERATURA CITADA

AMIN, Märio M., i 984 . Anälise Econômica da Situação Mundial. do Mercado de Exportação de Cacau 1962-1981. Belém, CEPLAC /DEPEA/COPES/DIMEQ. (Em publicação).

BANCO REAL, 1983. O Brasil na Reconquista do Mercado Interna cional do Café. Carta Econômica. $81: 1-5$.

BRASTLIA. Comissão Executiva Nacional do Alcool, 1983. Relatōrio Anual. Brasilia, CENAL. $45 \mathrm{p}$.

CENTRO DO COMERCIO DE CAFE. Revista do Comércio de Café. Rio de Janeiro, jun. 1974.

CENTRO dO COMERCIO DE CAFE. Revista do Comércio de Café. Rio de Janeiro, dez. 1975.

COMISSÃO EXECUTIVA DO PLANO DA LAVOURA CACAUEIRA. Cacau Informe Econômico. Brasilia, out/dez 1981.

COMISSÃO EXECUTIVA DO PLANO DA LAVOURA CACAUEIRA. Cacau Informe Econômico. Brasilia, jan/mar 1982.

COMISSÃO EXECUTIVA DO PLANO DA LAVOURA CACAUEIRA. Cacau Informe Econômico. Brasilia, jul/set 1983.

DELFIM, N, A., 1981. O Problema do Café no Brasil. São Paulo, IPE-USP, 1981. 348 p. (Ensaios Econômicos, 16).

FINLAYSON, A.J. e ZACHEA, W.M., 1983. The Politics of Interna tional Commodity Regulation: The Negotiation and Operation of the International Cocoa Agreements. Third World Quarterly. England, 5:386-417.

FUNDAÇAO GETULIO VARGAS, 1964. Conjuntura Econômica. Rio de Janeiro, ano XVIII, 5 .

FUNDAÇAO GETULIO VARGAS, 1965. Conjuntura Econômica. Rio de Janeiro, ano $X I X, 4$. 
FUndAç̃o GeTúlio VARGAS, 1966. Conjuntura Econômica. Rio de Janeiro, ano $X X, 1$.

FUNDACÃo GETÚl 10 VARGAS, 1967. Conjuntura Econômica. Rio de Janeiro, ano $X X 1,8$.

FUndACÃo GETÚl1O VARGAS, 1968. Conjuntura Econômica. Rio de Janeiro, ano $X X 11,2$.

FUndAça getúlio VARGAS, 1969. Conjuntura Econômica. Rio de Janeiro, ano $X X 111,1$.

FUndACÃO GETÚl10 VARGAS, 1970. Conjuntura Econômica. Retros pectiva Década de 60. Rio de Janeiro, ano $24,1$.

FUndAção GETÚliO VARGAS, 1971. Conjuntura Econômica. Rio de Janeiro, ano 25,6 .

FUNDACÃO GETÚl 10 VARGAS, 1972. Conjuntura Econômica. Retros pectiva do 1 e Semestre. Rio de Janeiro, ano $26,8: 30-32$.

FUNDACÃO GETÚlIO VARGAS, 1973. Conjuntura Econômica. Rio de Janeiro, ano $27,12: 28-29,72-109$.

FUNdAÇÃo GETÚlio VARGAS, 1975. Conjuntura Econômica. Rio de Janeiro, ano $29,12: 8-9$.

FUNDAÇÃo GETÚl 10 VARGAS, 1976. Conjuntura Econômica. Rio de Janeiro, $30,11: 8-10$.

FUNDACAO GETÚLIO VARGAS, 1979. Agroanalysis. Rio de Janeiro, 3. $5: 1-33$.

FUNDACÁO GETÚLIO VARGAS, 1979. Agroanalysis. Rio de Janeiro, 3, $9: 1-20$.

FUNDAÇ̃o GETÚl IO VARGAS, 1980. Agroanalysis. Rio de Janeiro, 4., $9: 1-45$.

FUndACÁO GETÚlIO VARGAS, 1981. Agroanalysis. Rio de Janeiro, 5, $9: 1-49$.

FUNDACÃO GETULIO VARGAS, 1981. Agroanalysis. Rio de Janeiro, 5, $10: 1-26$. 
FUNDAÇÃo GETÚLIO VARGAS, 1982. Agroanalysis. Rio de Janeiro, 6, $10 / 11$.

FUndAGÁo GETÚlio VARGAS, 1983. Agroanalysis. Rio de Janeiro, Z, $01: 2-12$.

GENEBRA. Conferência de las Naciones Unidas sobre Comercio y Desarrollo, 1980. Convenio Internacional del Cacao. Gene bra, Icco.

HARRY, J.G., 1968. Economic Policies Toward Less Developed Countries. Washington, The Brookings Institution. $271 \mathrm{p}$.

HOFFMAN, R. e VIEIRA, S., 1977. Anālise de Regressão - Uma Introdução à Econometria. São Paulo, Ed. Hucitec. 339 p.

HOFFMAN, R., 1980. Estatistica para Economistas. São Paulo, Pioneira. 379 p.

ILHEUS. Comissão Executiva do Plano da Lavoura Cacaueira,1973, Acordo Internacional do Cacau. Ilhéus, CEPLAC.

ILHEUS. Comissão Executiva do Plano da Lavoura Cacaueira,1975, Acordo Internacional do Cacau. Il héus, CEPLAC.

INTERNAT IONAL FEDERATION OF AGRICULTURAL PRODUCERS, Washington, 1972. World Agriculture.

JORNAL A TARDE, Bahia, 28 de novembro de 1981. Acordolnternacional do Cacau - Uma Retrospectiva.

JUNQUEIRA, F., 1981. O Brasil e o Mercado Internacional do Ca cau. Negociações Intergovernamentais. Brasilia, 95 p. MACEDO FILHO, F., 1968. Café Solüvel no Brasil - Histórico. Desenvolvimento $\times$ Conjuntura. Ano XII, 3 .

MENEZES, J.A.S., 1984. The International Cocoa Agreement the Consequences of Attempting to Reduce Price Instability in the 1980's. New lork, Cornell University. (Tese de Doutora mento). 
MONT'ALEgRE, 0., 1976. Estrutura dos Mercados de Produtos Primärios. Rio de Janeiro, IAA. 268 p. (Coleção Canavieira, 22).

MULLER, C., 1971. O Impacto do Acordo Internacional do Café, sobre o Preço do Café. Revista Brasileira de Economia. Rio de Janeiro, 3:131-148.

OBSERVADOR ECONOMICO E FINANCEIRO. 272: OUT. 1958 . p. $44-48$.

OBSERVADOR ECONOMICO E FINANCEIRO. 273: nOV. 1958. p. $48-53$.

OBSERVADOR ECONOMICO E FINANCEIRO. 274: dez. 1958. P. 38- 44.

SĂo PAUĹo. Secretaria da Agricultura, 1979. Política Cafeeira:

Diretrizes para Modernização e Desenvolvimento do Setor. In VEIGA, A., Coord. Ensaios sobre Politica Agrícola Brasileira.p. $233-294$.

SCHUTJER, A.W. e AYO JIDE, E. 196\%. Negotiating a World Cocoa Agreement: Analysis and Prospects. Bulletin 744. Pennsylva nia, $1-53$.

SMITH, G.W., 1981. Os Acordos Internacionais de Mercadorias, Tarifas, Quotas e Comércio: A Politica do Protecionismo. kio de Janeiro, Zahar ed., p. 186- 200 .

VEIGA, A., 1974. Efeitos da Politica Comercial-Brasileira no. Setor Agricola. Brasilia, $23 \mathrm{p}$.

Yo, Goan T., 1980. Operações a Termo de Mercadorias - "Commodi ties". São Paulo, Gedimex Ed. $220 \mathrm{p}$.

ZOCKUN, M.H.G.P. et ALII., 1976. A Agricultura e a Politica Comercial Brasileira. São Paulo, IPE. 136 p. (IPE monografias).

WICKIZER. V.D., 1943. The World Coffee Economy with Special Reference to Control Schemes. California, Food Research Institute Stanford University. $249 \mathrm{p}$. 
123

WONNACOTT, R.J. e WONHACOTT, T.H., 1976. Econometria. Rio de Janeiro, Livros Técnicos e Científicos Ed. $424 \mathrm{p}$. 
APENDICE 


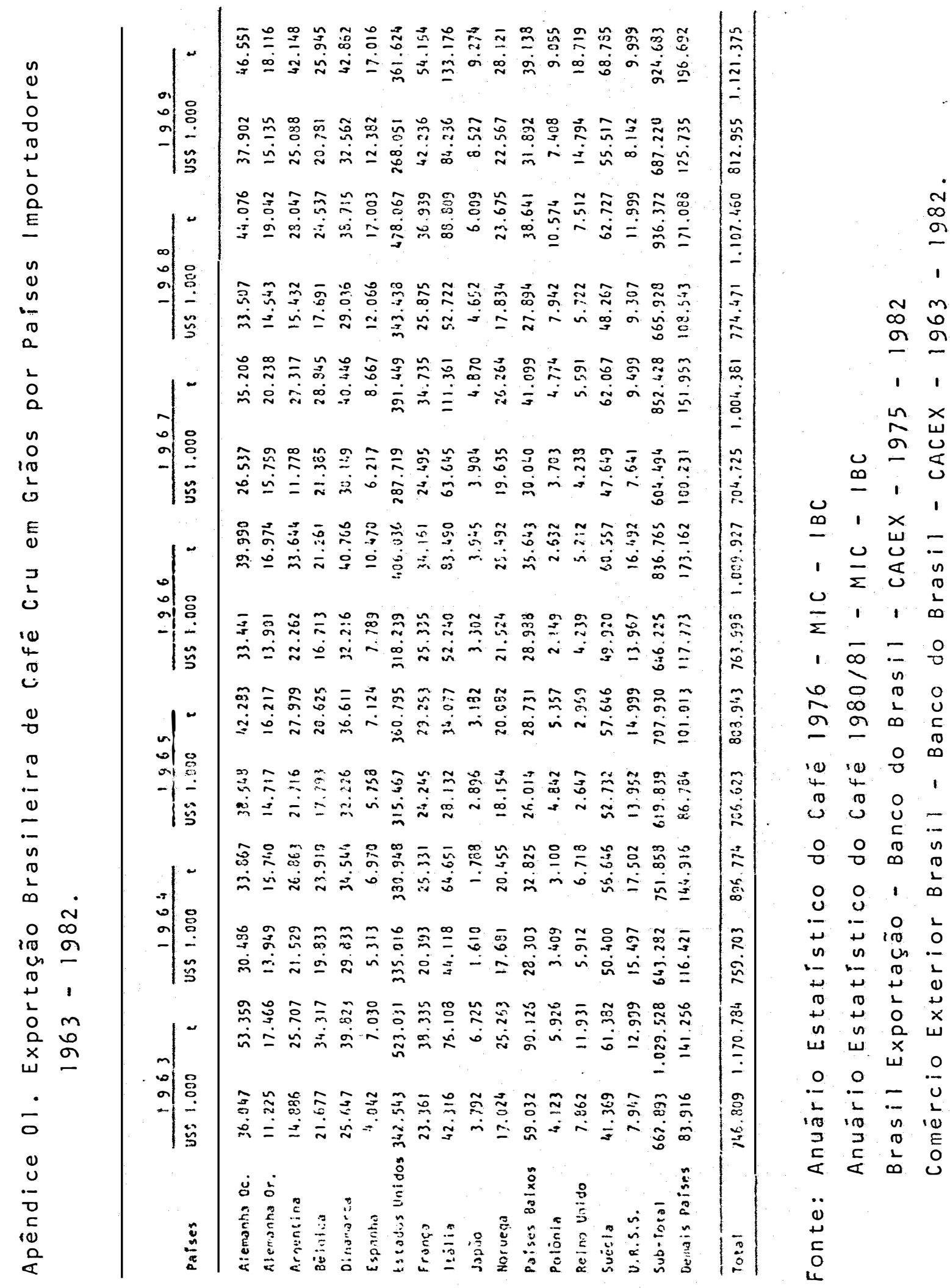




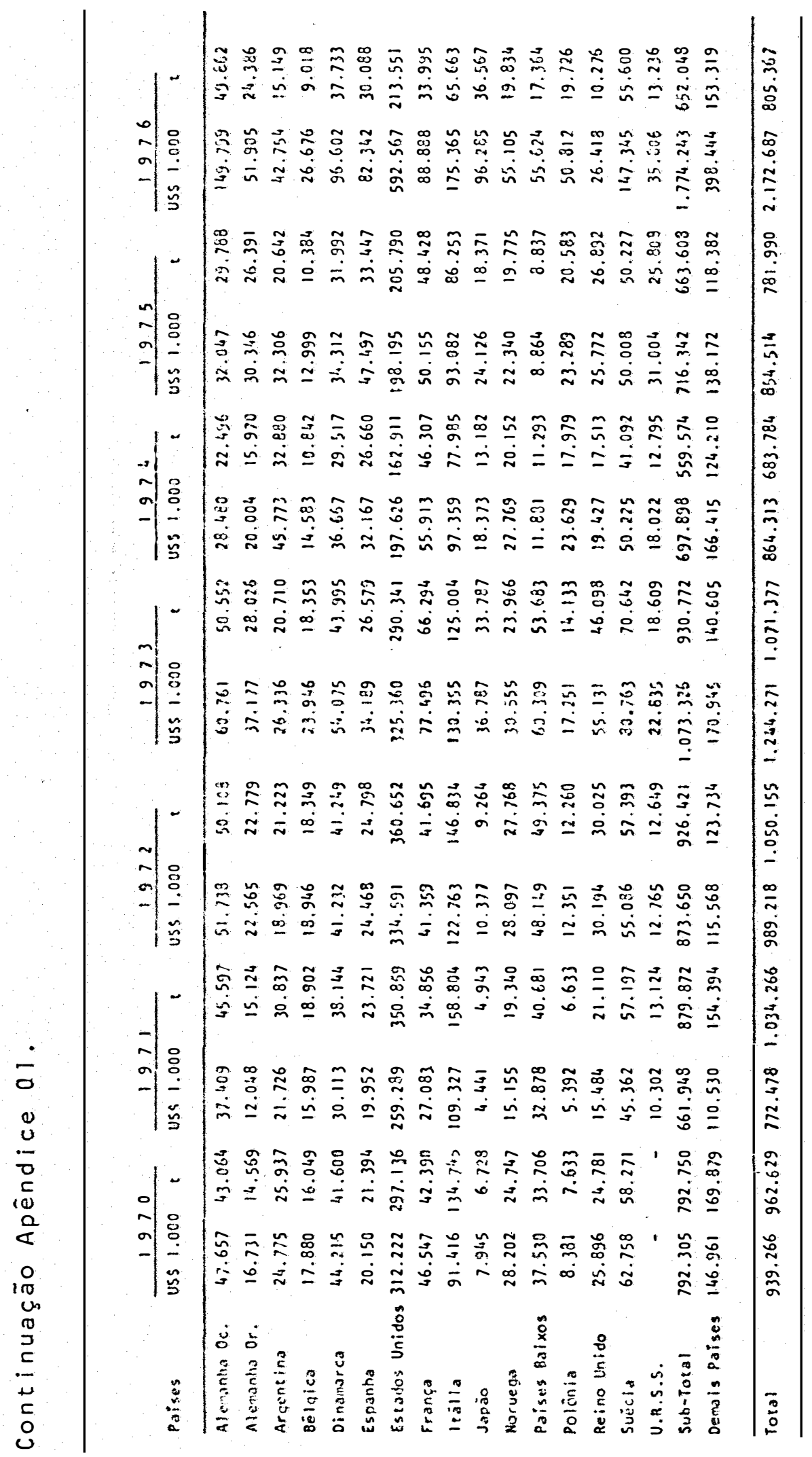




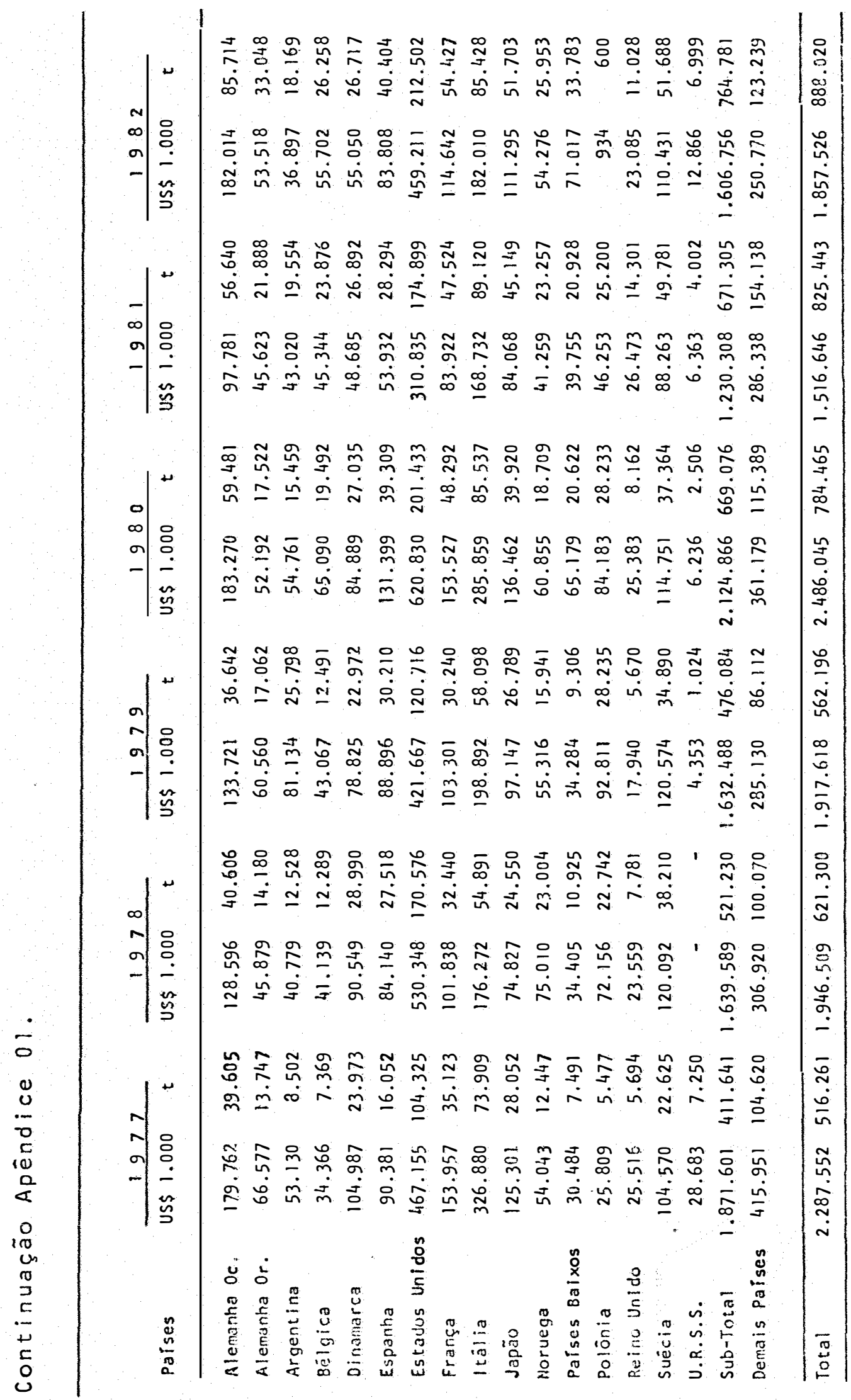

